UNIVERSIDADE DE BRASÍLIA

FACULDADE DE MEDICINA

PÓS-GRADUAÇÃO EM CIÊNCIAS MÉDICAS

PATRÍCIA MARIA FRITSCH

EFEITO IMUNOGÊNICO DE PEPTÍDEOS DA GLIADINA EM MODELO IN VITRO DA DOENÇA CELÍACA

Brasília-DF

2016 


\section{EFEITO IMUNOGÊNICO DE PEPTÍDEOS DA GLIADINA EM MODELO IN VITRO DA DOENÇA CELÍACA}

Tese de Doutorado apresentada ao Programa de PósGraduação em Ciências Médicas, da Faculdade de Medicina da Universidade de Brasília como parte dos requisitos necessários para obtenção do Título de Doutorado em Ciências Médicas.

Orientadora: Profa. Dra. Yanna Karla de Medeiros Nóbrega

Co-orientador: Prof. Dr. Riccardo Pratesi

Brasília-DF

2016 
PATRÍCIA MARIA FRITSCH

\section{EFEITO IMUNOGÊNICO DE PEPTÍDEOS DA GLIADINA EM MODELO IN VITRO DA DOENÇA CELÍACA}

Tese de Doutorado apresentada ao Programa de Pós-Graduação em Ciências Médicas, da Faculdade de Medicina da Universidade de Brasília como parte dos requisitos necessários para obtenção do Título de Doutorado em Ciências Médicas, Universidade de Brasília.

Aprovada em de de 2016

\section{BANCA EXAMINADORA}

Profa. Dra. Yanna Karla de Medeiros Nóbrega (UnB)

Prof. Dr. Rodrigo Coutinho de Almeida (UFPR)

Profa. Dra. Mariana Machado Hecht (UnB)

Profa. Dra. Pérola de Oliveira Magalhães Batista (UnB)

Prof. Dr. André Moraes Nicola (UnB) 
Este trabalho é dedicado aos meus pais, meu irmão, minhas irmãs e todos aqueles que nunca fugiram à luta. 


\section{AGRADECIMENTOS}

A CAPES pela bolsa de doutorado integral, fruto de políticas públicas de incentivo à pesquisa. Políticas desenvolvidas durante 12 anos de um governo de esquerda (20022014) que promoveu intercâmbio cultural e científico, investiu no ensino superior, em novas universidades federais, em escolas técnicas, na formação, valorização e contratação de professores gabaritados para desenvolver pesquisa e ciência.

Aos Professores Riccardo Pratesi e Lenora Gandolfi pelo convite para fazer parte da equipe do laboratório de pesquisa em Doença Celíaca desde 2009

A minha orientadora Yanna Karla de Medeiros Nóbrega pela oportunidade construída e por não medir esforços para tornar esse projeto possível

A minha família pelo conforto, amor, carinho e exemplo que são

Ao meu companheiro Eduardo Lourenço da Silva, pelo suporte, pela parceria e companheirismo

Aos meus amigos e colegas de laboratório pelo incentivo e aprendizado proporcionado: Lucas, Fernanda, Nicole, Mary, Zita, Isabella, Gabriel e Renata.

A equipe técnica do laboratório Cristina Simeoni, Adriana Pratesi e Isabella Márcia, agradeço pela aquisição de reagentes, pelo conserto de equipamentos e preparação de materiais utilizados no trabalho 
"Animados pela Fé e bem certos da vitória Vamos fincar nosso pé e fazer a nossa história. "

(José Fritsch e Pe. Ivo Oro) 


\section{RESUMO}

A Doença Celíaca (DC) é uma desordem sistêmica, imunomediada, desencadeada pelo consumo do glúten e suas prolaminas relacionadas (gliadina e glutenina) em indivíduos geneticamente predispostos. A doença combina fatores genéticos e ambientais para promover inflamação, dano na mucosa intestinal e o quadro clínico observado no doente celíaco. Uma vez presente na dieta do doente celíaco, a gliadina e seus fragmentos peptídicos entram em contato com as células da barreira epitelial intestinal e desencadeiam a resposta inflamatória antes mesmo que esses peptídeos atinjam a lâmina própria para iniciarem a resposta mediada pelo reconhecimento via MHC de classe II e seus alelos predisponentes HLA-DQ2 e DQ8. O tratamento baseado na dieta livre de glúten e o diagnóstico da DC estão bem estabelecidos. Entretanto o evento inicial da resposta inflamatória, a patogênese iniciada na barreira epitelial imediatamente após a interação com a gliadina e seus peptídeos ainda precisam ser elucidadas. Na tentativa de contribuir para a entendimento dos mecanismos de disparo da patogênese da DC, o presente trabalho propõe analisar a interação inicial da gliadina e seus peptídeos em células epiteliais Caco-2 e observar a modulação gênica, a produção de citocinas próinflamatórias e o estresse oxidativo mediados por essa interação. Nesse sentido, células Caco-2 foram cultivadas e estimuladas com LPS, gliadina e peptídeos imunogênicos e tóxicos da gliadina p56-88, p57-68, p69-82, p31-49, p57-68 $\mathrm{E}_{65}$ e p69-82 $\mathrm{E}_{72}$ por 6, 24 e 48 horas. O produto dessa interação e a modulação gênica produzida foram avaliados por qPCR e por dosagens do óxido nítrico e das citocinas pró-inflamatórias produzidas em cada tempo analisado. A gliadina e seus peptídeos imunogênicos foram tão eficientes quanto LPS em produzir inflamação nas células Caco-2, modulando a expressão de transcritos gênicos das citocinas pró-inflamatórias, principalmente de $I L-1$, $I L-6, I L-8$ e $I L-15$ especialmente nos tempos de 24 e 48 horas de interação, além de modularem a expressão do gene TLR-4. Para confirmar estes dados, a dosagem elevada de óxido nítrico e das citocinas IL-6, IL-21, IL-2, IL-8 e TNF- $\alpha$ evidenciou a presença de uma resposta inflamatória induzida pelas interações estudadas. Após análise dos dados, podemos inferir que a gliadina intacta ou seus peptídeos modularam a resposta inflamatória em células Caco-2, tal como observado in vivo no doente celíaco. Observamos que o receptor TLR-4 pode apresentar um papel importante na patogênese da DC, principalmente no reconhecimento da gliadina e seus peptídeos no evento inicial da resposta imunológica desencadeada pela célula epitelial intestinal. Os resultados sugerem que TLR-4 poderá representar uma nova rota de entrada da gliadina e seus derivados para a lâmina própria intestinal, contribuindo para o entendimento desta lacuna na patogênese da doença.

Palavras-chaves: Doença celíaca, peptídeos de gliadina, Caco-2, expressão gênica, estresse oxidativo, IL-1, IL-2, IL-6, IL-8, IL-15, IL-21, TNF- $\alpha$, TLR-4. 


\begin{abstract}
Celiac disease is a systemic, immunomomediated disorder, triggered by the ingestion of gluten and its related prolamins (gliadin and glutenin) in genetically predisposed individuals. In celiac disease, genetic and environmental factors are combined to promote inflammation, damage of the intestinal mucosa and the characteristic clinical manifestations of celiac patients. Once present in the celiac patient's dietary gliadin and its fragments interact with cells from the epithelial intestinal barrier, and initiate an inflammatory response even before reaching the lamina propria. This process is mediated by specific MHC-II molecules' recognition, HLA-DQ2/DQ8. Both the treatment, based on a gluten free diet, and the diagnosis of celiac disease are well established. However, the initial inflammatory response which takes place in the epithelial intestinal barrier immediately after the interaction between the intestinal cells, gliadin, and its peptides, still need to be elucidated. To contribute to the understanding of this mechanisms, this work intends to analyse the initial interaction between gliadin, its immunogenic peptides, and Caco- 2 cells, by studying the differences in gene expression, inflammatory cytokines production and the oxidant stress. Caco-2 cells were cultured and exposed to LPS, gliadin and its immunogenic peptides P56-88, P5768, P69-82, P31-49, P57-68E65 and P69-82E72 for 6, 24 and 48 hours. The products of these interactions were evaluated using qPCR, to analyze the differential expression of target mRNAs, and by dosing the production of Nitric oxide and pro-inflammatory cytokines at the stipulated times. Our results showed that gliadin and its immunogenic peptides were as efficient as LPS in activating an immune response in Caco- 2 cells. They all promoted oxidative stress, transcription of $I L-1, I L-6, I L-8$ e IL-15 and production of the cytokines IL-6, IL-21, IL-2 e IL-8, mainly after 24 and 48 hours of challenge. We could also observe high levels of TNF- $\alpha$ cytokine and TLR4 transcripts. After analyzing our data, we could infer that both gliadin and its peptides could modulate the inflammatory response in Caco-2 cells, which is consistent with what is observed in vivo in celiac patients. We noticed that TLR-4 receptor can have an important role in the pathogenesis of celiac disease, mainly during the initial phase of the inflammatory response when gliadin and its peptides are recognized after the interaction with epithelial intestinal cells. This receptor could also be involved in the interiorization of gliadin and its peptides, contributing to the understanding of this gap in the pathogenesis of celiac disease.
\end{abstract}

Key Word: celiac disease, gliadin, peptides, Caco-2, gene expression, cytokines, IL-1, IL-2, IL-6, IL-8, IL-15, IL-21, TNF- $\alpha$, TLR-4. 


\section{LISTA DE FIGURAS}

Figura 1 - Organograma para diagnóstico da DC …...................................................... 4

Figura 2 - Resposta inflamatória e autoimune na DC ….............................................. 8

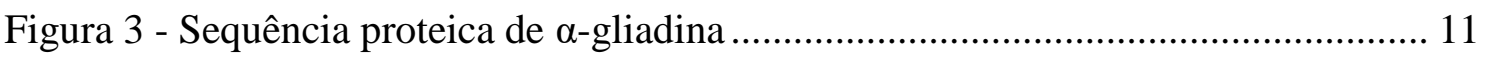

Figura 4 - Desamidação promovida pela enzima tTG2 ............................................. 12

Figura 5 - Dano no tecido epitelial causado pelo efeito tóxico e imunogênico de

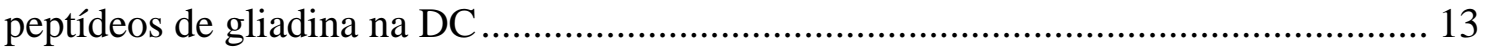

Figura 6 - Representação da ativação da via NFkB................................................... 15

Figura 7 - Delineamento experimental da interação dos peptídeos de gliadina em células

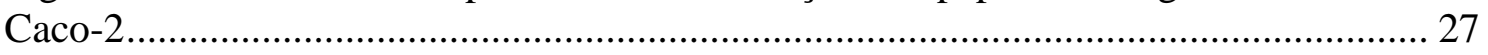

Figura 8 - Ilustração do ensaio de ELISA para as citocinas dosadas ........................... 32

Figura 9 - Padronização da quantidade de células Caco-2 ......................................... 35

Figura 10 - Teste para estabelecer a concentração de LPS ........................................... 36

Figura 11 - teste para estabelecer a concentração de gliadina .................................... 36

Figura 12 - Interação química entre reagentes ...................................................... 37

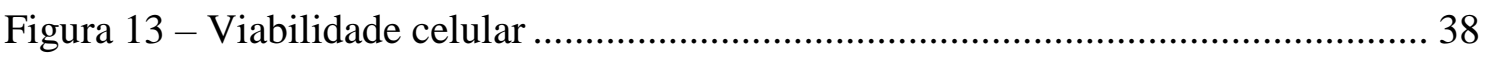

Figura 14 - Variação dos valores de Ct dos genes antes de normalizados ..................... 40

Figura 15 - Modulação da expressão de transcritos gênicos em células Caco-2 estimuladas com LPS e gliadina por 6 horas, 24 horas e 48 horas ............................... 44

Figura 16 - Modulação da expressão de transcritos gênicos em células Caco-2 estimuladas com LPS e gliadina por 6 horas, 24 horas e 48 horas ............................... 46

Figura 17 - Modulação da expressão de transcritos gênicos em células Caco-2 estimuladas com gliadina e p56-88 (P1) por 6 horas, 24 horas e 48 horas

Figura 18 - Modulação da expressão de transcritos gênicos em células Caco-2 estimuladas com gliadina e p56-88 (P1) por 6 horas, 24 horas e 48 horas ................... 51

Figura 19 - Modulação da expressão de transcritos gênicos em células Caco-2 estimuladas com gliadina e p57-68 (P2) por 6 horas, 24 horas e 48 horas

Figura 20 - Modulação da expressão de transcritos gênicos em células Caco-2 estimuladas com gliadina e p57-68 (P2) por 6 horas, 24 horas e 48 horas 
Figura 21 - Modulação da expressão de transcritos gênicos em células Caco-2 estimuladas com gliadina e p69-82 (P3) por 6 horas, 24 horas e 48 horas 57

Figura 22 - Modulação da expressão de transcritos gênicos em células Caco-2 estimuladas com gliadina e p69-82 (P3) por 6 horas, 24 horas e 48 horas

Figura 23 - Modulação da expressão de transcritos gênicos em células Caco-2 estimuladas com gliadina e p31-43 (P4) por 6 horas, 24 horas e 48 horas

Figura 24 - Modulação da expressão de transcritos gênicos em células Caco-2 estimuladas com gliadina e p31-43 (P4) por 6 horas, 24 horas e 48 horas 64

Figura 25 - Modulação da expressão de transcritos gênicos em células Caco-2 estimuladas com gliadina e p57-68: 65 (P5) por 6 horas, 24 horas e 48 horas 66

Figura 26 - Modulação da expressão de transcritos gênicos em células Caco-2 estimuladas com gliadina e p57-68E 65 (P5) por 6 horas, 24 horas e 48 horas 68

Figura 27 - Modulação da expressão de transcritos gênicos em células Caco-2 estimuladas com gliadina e p69-82 $\mathrm{E}_{72}$ (P6) por 6 horas, 24 horas e 48 horas 70

Figura 28 - Modulação da expressão de transcritos gênicos em células Caco-2 estimuladas com gliadina e p69-82E 72 (P6) por 6 horas, 24 horas e 48 horas 72

Figura 29 - Dosagem de Óxido Nítrico (NO) em sobrenadante de cultura de célulasCaco-2 após interação com LPS, gliadina e seus peptídeos em 6, 24 e 48h ....... 73

Figura 30 - Dosagem da citocina Interleucina 6 (IL-6) em sobrenadante de cultura de células Caco-2 após interação com LPS, gliadina e seus peptídeos em 6, 24 e 48h ...... 75

Figura 31 - Dosagem da citocina Interleucina 21 (IL-21) em sobrenadante de cultura de células Caco-2 após interação com LPS, gliadina e seus peptídeos em 6, 24 e 48h ...... 76

Figura 32 - Dosagem da citocina Interleucina 2 (IL-2) em sobrenadante de cultura de células Caco-2 após interação com LPS, gliadina e seus peptídeos em 6, 24 e 48h ...... 77

Figura 33 - Dosagem da citocina Interleucina 8 (IL-8) em sobrenadante de cultura de células Caco-2 após interação com LPS, gliadina e seus peptídeos em 6, 24 e 48h ....... 78

Figura 34 - Dosagem da citocina Fator de Necrose Tumoral (TNF- $\alpha$ ) em sobrenadante de cultura de células Caco-2 após interação com LPS, gliadina e seus peptídeos em 6, 24 e $48 h$ 79 


\section{LISTA DE TABELAS}

Tabela 1 - sequência dos peptídeos de gliadina sintetizados ......................................... 22

Tabela 2- Grupos experimentais e seus respectivos estímulos..................................... 26

Tabela 3 - Conjuntos dos genes escolhidos, identidade e sequência dos pares de primers usados por q-PCR

Tabela 4 - Otimização dos primers empregados na reação de q-PCR. 39

Tabela 5- Distribuição dos fold-change ( $\log 2)$ dos genes superexpressos e subexpressos ao longo do tempo 


\section{LISTA DE ABREVIATURAS E SIGLAS}

APC Célula Apresentadora de Antígeno

ATCC American Type Culture Colection

Caco-2 Linhagem celular de adenocarcinoma coloretal

CD71 Receptor de transferrina

cDNA DNA complementar

$\mathrm{CO}_{2} \quad$ Dióxido de carbono

COX Enzima ciclooxigenase

$\mathrm{Ct} \quad$ Threshold cycle

DC Doença Celíaca

DGP Anti-Peptídeo desamidado de Gliadina

DMEM Meio Eagle Modificado por Dubelcco

DMSO Dimetilsulfóxido

DNA Ácido desoxiribonucleico

DNAse Enzima que degrada DNA

EDTA Ácido etilenodiamino tetra-acético

EGFR Receptor do fator de crescimento epidermal

ELISA Enzyme Linked Immuno Sorbent Assay

EMA Anti-endomísio

eNOS Enzima óxido nítrico sintetase endotelial

ESPGHAN European Society for Paediatric Gastroenterology Hepatology and Nutrition

Fc Região Fc da imunoglobulina

FDA Food and Drug Administration

GAPDH Gliceraldehide-3-Phosphate Dehidrogenase

GFD gluten-free-diet

GWAS Genome Wide Association Studies

HEPES Ácido Etanosulfônico 4-2-Hidroetil Piperazina-1

HLA Antígeno Leucocitário Humano

HPLC Reverse-phase High Performance Liquid Chromatography

HRP Peroxidase de rábano

IELTs Linfócitos intra epitelial

IFN- $\gamma \quad$ Interferon gama 
IgA Imunoglobulina A

IgG Imunoglobulina $\mathrm{G}$

IL-1 Interleucina-1

IL-15 Interleucina 15

IL-1R Receptor de interleucina-1

IL-6 Interleucina-6

IL-8 Interleucina-8

iNOS Enzima óxido nítrico sintetase induzível

IкB Inibidor da atividade de kappaB

LABDC Laboratório de Pesquisas em Doença Celíaca

LabIBC Laboratório Interdisciplinar de Biociências

LADIC Laboratório de Pesquisas em Doenças Imunogenéticas e Crônicodegenerativas

LPS Lipopolissacarideo E.colli

MHC Complexo principal de histocompatibilidade

NEED N-1-naphthyl etilenodiamina hidrocloreto

$\mathrm{NF \kappa B} \quad$ Fator de transcrição nuclear kappaB

NK Células natural killers

nNOS Enzima neural óxido nítrico sintetase

NO Óxido nítrico

NOS Enzima óxido nítrico sintetase

NT Não tratado

P1 33mer $\alpha$-9-gliadin (56-88)

P2 $\alpha-9$-gliadin (57-68) N-terminal

P3 $\quad \alpha-9$-gliadin (69-82) C-terminal

P4 $\alpha$-9-gliadin (31-43) C-terminal

P5 $\quad \alpha$-9-gliadin (57-68E65) N-terminal Desamidado

P6 $\quad \alpha-9$-gliadin (69-82E72) C-terminal Desamidado

PAMPs Padrões Moleculares Associados a Patógenos

PBS Tampão Fosfato-Salino

PRR Receptores de Reconhecimento Padrão

q.s.p quantidade suficiente para

q-PCR Reação em cadeia da polimerase - quantitativa

RE Elementos responsivos 
RNA Ácido ribonucleico

RNAse Enzima que degrada RNA

RNS Especies nitrogênio-reativas

ROS Espécies oxigênio-reativas

RT Transcrição reversa

SFB Soro Fetal Bovino

SNPs Single-Nucleotide Polymorphisms

T CD4 Linfócitos T tipo CD4

T84 Linhagem celular de carcinoma humano transplantável

t-ANOVA Teste de análise de variância

TJ Junções epiteliais ocludentes

TLR Receptor toll-like

TLR-2 Toll-like receptor 2

TLR-4 Toll-like receptor 4

Tm Temperatura de melting

TNFR Receptor do fator de necrose tumoral

TNF- $\alpha \quad$ Fator de necrose tumoral alpha

tTG2 Transglutaminase tecidual do tipo 2

UnB Universidade de Brasília

WST-8 Sal monossódico de tetrazólio

$\Delta \mathrm{RN} \quad$ Variação do sinal residual de fluorescência 


\section{SUMÁRIO}

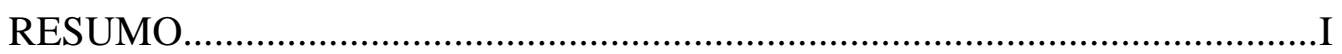

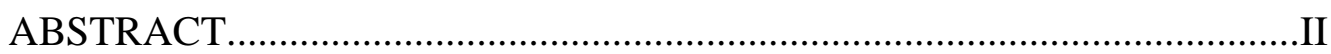

LISTA DE FIGURAS.........................................................................

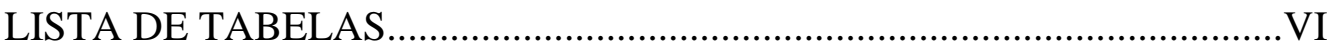

LISTA DE ABREVIATURAS E SIGLA .....................................................VII

1 INTRODUÇÃ

1.1 Importância do trigo para a humanidade ............................................ 1

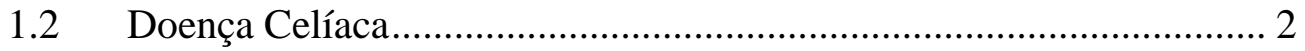

1.3 Dignóstico e Tratamento ................................................................. 3

1.4 Patogênese da Doença Celíaca .......................................................... 6

1.5 O Papel da gliadina na Doença Celíaca .......................................... 10

1.6 Efeito imunogênico e citotóxico gerado pela gliadina...................... 12

1.7 Células Caco-2 como modelo de estudo para Doença Celíaca ......... 16

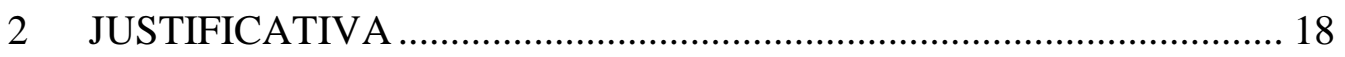

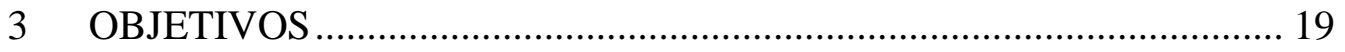

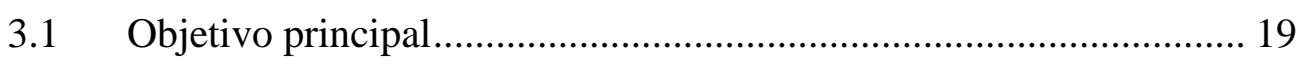

3.2 Objetivos secundários ................................................................. 19

4 MATERIAIS E MÉTODOS .............................................................. 20

4.1 Fase Analítica I........................................................................... 20

4.1.1 Cultura in vitro das Células Caco-2 2......................................... 20

4.1.2 Estímulos utilizados nos estudo............................................. 21

4.1.3 Ensaio de viabilidade celular .................................................. 22

4.1.4 Ensaio de otimização da reação de q-PCR ................................... 24

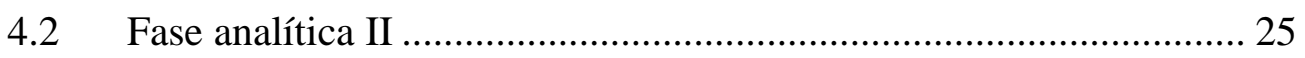

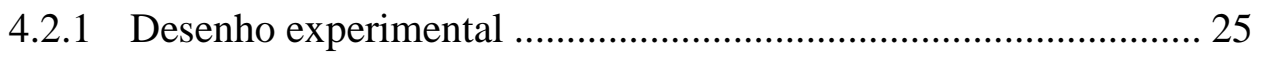

4.2.2 Definição dos genes de interesse para o estudo........................... 28

4.2.3 Reação em Cadeia da Polimerase quantitativa em Tempo-Real (qPCR) $\quad 29$

4.2.4 Dosagem de Óxido Nítrico 30 


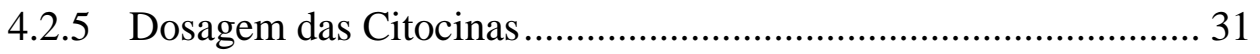

4.2.6 Análise Estatística.................................................................... 33

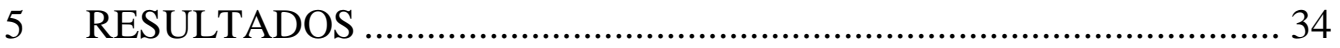

5.1 Resultados da Fase Analítica I ................................................... 34

5.1.1 Seleção da Concentração Celular .............................................. 34

5.1.2 Ensaio para a Seleção da Concentração de LPS e gliadina .......... 35

5.1.3 Ensaio de Viabilidade Celular ..................................................... 37

5.1.4 Otimização do ensaio de q-PCR ................................................ 38

5.2 Resultados da Fase Analítica II .................................................... 39

5.2.1 Análise do fold-change $\left(\log ^{2}\right)$ obtido por q-PCR ....................... 39

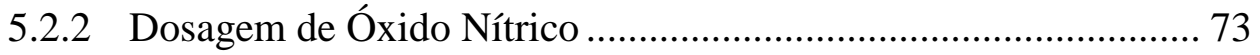

5.1.2. Dosagem das Citocinas ............................................................. 74

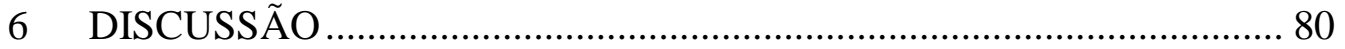

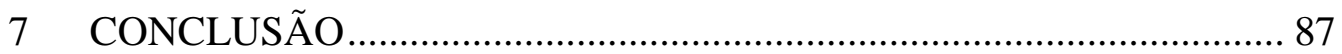

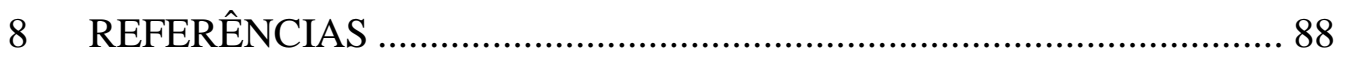




\section{INTRODUÇÃO}

\subsection{Importância do trigo para a humanidade}

Por mais de dez mil anos a humanidade tem desenvolvido o cultivo de cereais, em especial a lavoura do trigo, o que permitiu sua fixação em territórios férteis. Isso contribuiu para a formação de povoados e cidades, onde a segurança de estocar os grãos e garantir a alimentação por longos períodos não só possibilitou ao homem abandonar a necessidade exclusiva de caçar e coletar, como também lhe permitiu tempo para se especializar em outras atividades laborais, desenvolver as artes e as ciências (CURTIS et al., 2002).

O trigo é, ainda hoje, a base alimentar da maior parte das civilizações da Europa, do Oeste Asiático e do Norte da África e supera em produção e área plantada o cultivo de outras espécies como arroz, milho e batata. O trigo é o componente alimentar mais utilizado pela humanidade devido sua adaptabilidade agrícola à diferentes climas, a facilidade de ser estocado e de ter seus grãos convertidos em farinha, o que possibilita a produção de uma grande diversidade de alimentos (TOSI et al., 2011).

O glúten é a proteína que constitui a maior parte do grão do trigo, localizado especificamente no endosperma, que quando triturado forma farinha. As frações proteicas do glúten (gliadina e glutenina) formam uma rede contínua de proteínas que, quando misturadas com água, conferem elasticidade e viscosidade à massa, o que permite a transformação da farinha do trigo em pães, massas, dentre outros alimentos (TOSI et al., 2011). Embora amplamente consumido mundo a fora como a principal fonte de carboidratos, uma das proteínas presentes no glúten, a gliadina, tem gerado crescente intolerância alimentar observada especialmente nos descendentes de civilizações que historicamente desenvolveram a cultura do trigo e que construíram sua base alimentar a partir desse cereal (LOSOWSKY et al., 2008).

A toxicidade desencadeada pelo consumo de alimentos elaborados a partir do trigo pode ser observada desde o desenvolvimento de sensibilidade ao glúten, alergias e até Doença Celíaca (DC). A primeira descrição da DC foi encontrada nos escritos do fisiologista grego Arateus da Capadócia no século II d.C. (LOSOWSKY et al., 2008). Contudo, ainda hoje verifica-se que os conhecimentos sobre o desenvolvimento da DC 
possuem lacunas a serem preenchidas quanto às respostas inflamatórias e os mecanismos autoimunes desencadeados nos pacientes celíacos (SHAMIR et al., 2014).

\subsection{Doença Celíaca}

A DC é uma desordem sistêmica, imunomediada, desencadeada necessariamente por meio do contato do glúten e suas prolaminas relacionadas com indivíduos geneticamente predispostos. Essa doença é caracterizada pela presença da combinação variável de manifestações clínicas dependentes do glúten, em que na ausência dessa proteína se observa a melhora dos sinais e sintomas clínicos no doente celíaco (HUSBY et al., 2012; ABADIE et al., 2011).

A DC pode manifestar-se em qualquer fase da vida, mas é mais frequentemente diagnosticada na infância pela presença de quadro clínico de perda de peso, dor abdominal recorrente, distensão abdominal, esteatorréia, diarreia, constipação, baixa absorção de nutrientes e fadiga (HUSBY et al., 2012). O doente celíaco pode desencadear anemia em decorrência à baixa absorção de ferro, baixa absorção de cálcio culminando em osteopenia e osteoporose, depressão e problemas neurológicos como convulsões de repetição e cefaleia persistente, dentre outras manifestações (LEFFLER et al., 2015).

Verifica-se também que a DC pode estar associada a eventos não gastrointestinais como por exemplo déficit de crescimento, infertilidade, dermatites, dentre outros. É possível ainda a instalação da DC ocorra de maneira não acompanhada de quaisquer sinais ou sintomas, situação em que a doença é subdiagnosticada, o que dificulta o tratamento e o reestabelecimento da saúde do paciente celíaco. Também pode ser caracterizada pela expressão clínica de sinais e sintomas secundários, como por exemplo o comprometimento de órgãos e sistemas não necessariamente gastrointestinais (HUSBY et al., 2012; ZEVIT \& SHAMIR et al., 2014).

A presença do glúten na dieta do doente celíaco leva ao desenvolvimento de alterações morfológicas nos enterócitos, causando prejuízo na capacidade funcional dessas células, promovendo processo inflamatório persistente com infiltração de células do sistema imunitário na lâmina própria, aumento da expressão e deslocamento de anticorpos diversos para os tecidos intestinais. Esses eventos contribuem para o 
desencadeamento de resposta autoimune que levam a atrofia vilositária intestinal e manifestações dos sinais e sintomas (ABADIE et al., 2011; HUSBY et al., 2012).

\subsection{Dignóstico e Tratamento}

O variável grau de atrofia vilositária associada à hiperplasia das criptas da mucosa intestinal pode ser identificado por exame histopatológico, através da avaliação de células obtidas por biópsia de tecido duodenal ou jejunal. A infiltração de linfócitos da mucosa do intestino delgado, causada pela resposta das células $\mathrm{T}$ ao auto antígeno da transglutaminase tecidual do tipo 2 (tTG2), ao anti-endomísio (EMA) (Figura 1), e a anticorpo contra peptídeos desamidados de gliadina (DGP), podem ser detectados por testes imunoenzimático como o Enzyme-Linked Immunosorbent Assay (ELISA) e de imunofluorescência indireta (HUSBY et al., 2012; LUDVIGSSON et al., 2013).

Além do diagnóstico baseado em testes sorológicos para identificação desses anticorpos, o diagnóstico pode contar ainda com a utilização de exames de genotipagem com alta sensibilidade e especificidade. Esses exames identificam os alelos do Human Leucocyte Antigen (HLA), HLA-DQ2 e HLA-DQ8, que são codificados pelos genes do Complexo Principal de Histocompatibilidade (MHC) de classe II presentes na maioria dos pacientes celíacos (90\% dos pacientes com DC possuem DQ2 e $10 \%$ dos pacientes possuem DQ8), o que confere uma forte base genética à DC e possibilita inferir o risco de predisponibilidade à DC nos familiares (HUSBY et al., 2012; LUDVIGSSON et al., 2013; MEGIORNI et al., 2009). 


\section{Diagnóstico da DC}

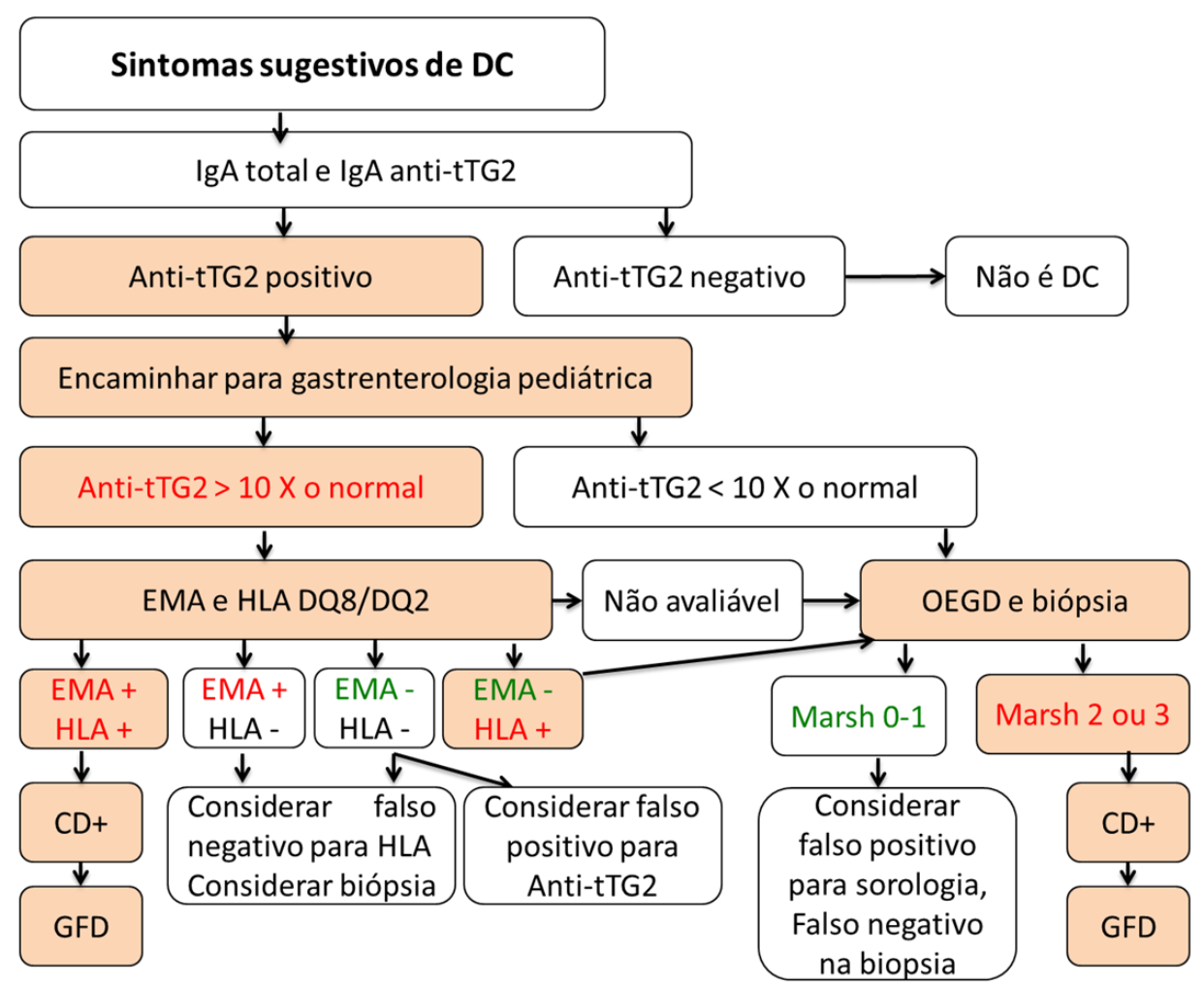

Figura 1 - Organograma para diagnóstico da DC

DC (Doença Celíaca); EMA (Anti Endomísio); GFD (gluten-free diet); HLA (human leukocyte antigen); IgA(imunoglobulina A); IgG(imunoglobulina G); tTG2 (transglutaminase tecidual tipo 2); OEGD (esofagogastroduedenoscopia)

Adaptado de HUSBY et al., 2012

Neste contexto, de acordo com a European Society for Paediatric Gastroenterology Hepatology and Nutrition (ESPGHAN) (Figura 1), o diagnóstico da DC precisa ter uma abordagem ampla que auxilie: 1) na identificação de todo o quadro clínico menos ou mais evidente, que abrangem vários órgãos e sistemas; 2) na detecção de sorologia que confirme a presença dos anticorpos específicos para DC; 3) na avaliação da genética para definir o risco de desenvolvimento da DC e 4) na observação da melhora do paciente após iniciar dieta livre de glúten (Figura 1).

O único tratamento disponível para DC é a dieta que exclui todos os alimentos que contém glúten. Essa dieta deverá ser mantida por toda a vida, o que propicia melhora dos sintomas, remissão do processo inflamatório e restabelecimento da mucosa intestinal em alguns meses (HUSBY et al., 2012; LUDVIGSSON et al., 2013). 
Para um produto alimentício ser considerado livre de glúten deve conter no máximo entre 100 e $20 \mathrm{mg} / \mathrm{kg}$ de traços de glúten, e estudos tem indicado que esses alimentos industrializados purificados e livres de glúten, são seguros quando inclusos na dieta de um paciente celíaco. Observa-se que a mucosa intestinal é reestabelecida e assim mantém-se morfologicamente normal por longos períodos. Nenhuma diferença foi observada quando comparado resultados clínicos de biópsias de pacientes celíacos com pacientes não celíacos em dieta livre de glúten (HISCHENHUBER et al., 2006).

Mesmo depois de aderir à dieta livre de glúten 20 a $80 \%$ dos pacientes continuam sofrendo com os sintomas e com as lesões na mucosa (Tuire et al., 2012). Este fato é justificado pelo consumo não intencional de alimentos originalmente livres de glúten, mas contaminados com traços desta proteína. Geralmente esses alimentos são processados ou embalados em equipamentos contaminados com outros alimentos que continham glúten (FARAGE et al., 2016).

Para promover a qualidade de vida e segurança alimentar do paciente celíaco é preciso alternativas terapêuticas além da dieta livre de glúten. A indústria alimentícia tem desenvolvido novas terapias para melhorar a dieta e até mesmo com objetivos de suspender a dieta livre de glúten (MÄKI et al., 2014). Dentre as alternativas, por exemplo, estão: o uso de glutenase ALV003 para degradar o glúten ingerido e atenuar os danos na mucosa de pacientes celíacos em dieta livre de glúten contaminada com 2000 mg glúten por dia (LÄHDEAHO et al., 2014); uso de acetato de larazotide, também conhecido como AT-1001, é regulador de junções epiteliais TJ e atualmente tal estudo está em fase 2 (KHALEGHI et al., 2016); o uso do polímero BL-7010, em camundongos sensibilizados ao glúten, que liga-se ao glúten sequestrando-o para ser eliminado nas fezes (MCCARVILLE et al., 2014); o desenvolvimento da vacina Nexvax2 tem objetivo de ser usada como imunoterapia para induzir tolerância ao glúten; entre outras abordagens, como inibidores de tTG-2 e ligantes de receptores celulares entre outras em desenvolvimento (VEERARAGHAVAN et al., 2015; FREEMAN et al., 2015). Atualmente, nenhuma droga ou novo tratamento está disponível no mercado. 


\subsection{Patogênese da Doença Celíaca}

A patogênese da DC é iniciada quando o doente celíaco se alimenta de dieta rica em glúten. Em indivíduos não celíacos o glúten é clivado, por ação de enzimas digestivas, em fragmentos muito pequenos para desencadearem resposta imunogênica e são digeridos pelo sistema gastrointestinal sem causar danos ao indivíduo. Porém, em doentes celíacos, a digestão do glúten é incompleta e gera fragmentos de gliadina que iniciam uma resposta imune inata e adaptativa. Essa resposta resulta em dano tecidual da mucosa intestinal e manifestação dos sintomas clínicos da DC (FERRANTI et al., 2007).

Estes fragmentos peptídicos de gliadina passam através da barreira epitelial do intestino em direção à lâmina própria por vários mecanismos descritos na literatura: (1) por via transcelular, onde o glúten é endocitado em lisossomos, que o degradam em pequenos peptídeos não imunogênicos (FASANO et al., 2011); (2) por via paracelular, através da regulação das junções TJ responsáveis pela união das células epiteliais, promovendo uma alteração da permeabilidade celular e consequentemente a entrada de peptídeos da gliadina na mucosa, como por exemplo, a regulação através de zonulina produzida pelas células epiteliais de pacientes celíacos que alteram a permeabilidade entre as células epiteliais (HEYMAN \& MENARD 2009); (3) por transporte transepitelial, em células de pacientes celíacos, em que há aumento na expressão de CD71 (receptor de transferrina). Esse receptor reconhece o IgA complexada com gliadina através da porção $\mathrm{Fc}$ da imunoglobulina, e libera essa associação sem processamento na lâmina própria (MATYSIAK-BUDNIK et al., 2008).

Embora estes mecanismos de entrada e processamento pelas enzimas digestivas estejam descritos na literatura acredita-se que estes peptídeos interajam com as células epiteliais intestinais e produzam resposta inflamatória antes de se apresentarem na lâmina própria, promovendo alterações gênicas nesta células por mecanismos ainda não completamente elucidados (FERRANTI et al., 2007), que é o propósito deste estudo.

Uma vez presente na lâmina própria, o peptídeo é modificado pela ação enzimática com a tTG2 e adquire uma carga residual negativa que aumenta a afinidade do complexo gliadina-tTG2 e dos peptídeos de gliadina com as moléculas do MHC de 
classe II HLA-DQ2/DQ8 (CAPUTO et al., 2012; SIMON-VECSEI et al., 2012; RAUHAVIRTA et al., 2011).

Ainda na lâmina própria, os peptídeos da gliadina são reconhecidos e processados pelas Células Apresentadoras de Antígeno (APC) via MHC de classe II HLA-DQ2/DQ8, e são apresentados a células T CD4, que se tornam ativas e passam a produzir IFN- $\gamma$ e IL-15. Os linfócitos T-CD4, ativados pelas APC na lâmina própria, diferenciam-se em linfócitos intraepiteliais (IELTs) e infiltram-se entre as células epiteliais em resposta a estímulos da IL-15 produzida pelos enterócitos (figura 2). Ainda em resposta a IL-15, os IELTs passam a exibir na sua membrana celular receptores para células Natural killers (NK), o que promove o recrutamento em cascata de novas células NK, culminando em destruição da barreira epitelial, hiperplasia de criptas e atrofia das vilosidades intestinais (ABADIE \& JABRI, 2014; SOLLID \& JABRI, 2013; BARONE et al., 2011).

As APCs migram para o nódulo linfático mesentérico e apresentam os peptídeos de gliadina complexado com tTG2 para células T CD4 imaturas. Nos nódulos mesentéricos, as células T-CD4 diferenciam-se em células T-CD4 efetoras (T-CD4 $\left.{ }^{+}\right), 0$ que amplia a proliferação de células B reativas ao complexo gliadina-tTG2. As células B reativas diferenciam-se em plasmócitos e passam a produzir anticorpos IgA e IgG, não apenas contra resíduos de gliadina modificados, como também contra as tTG2, que eventualmente ainda estiverem complexadas com estes peptídeos (MAIURI et al., 2003; MERESSE et al., 2006). 


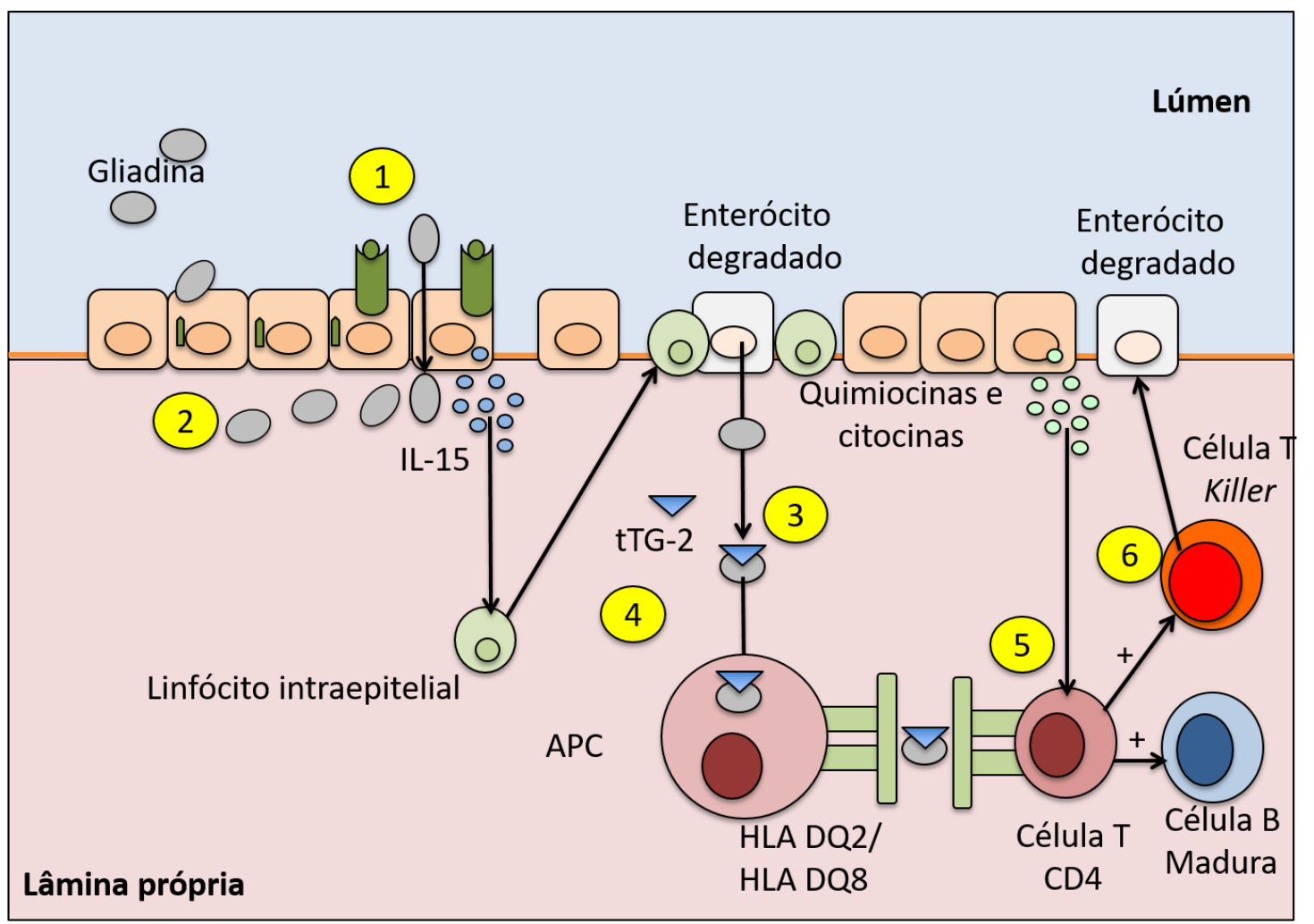

Figura 2 - Resposta inflamatória e autoimune na DC

A ingestão de fragmentos de glúten libera remodela as junções TJ que aumentam a permeabilidade células. Antígenos do glúten ganham acesso a lâmina própria e ativa a expressão de citocinas pró-inflamatórias (2). tTG2 desamida os fragmentos da gliadina (3), aumentando sua afinidade pelas moléculas HLA DQ2/DQ8 (4). APCs apresentam a gliadina para células T (5). As células T ativam células NK para atacarem o enterócito (6). Células inflamatórias ativadas migram para o epitélio intestinal causando inflamação e sintomas gastrointestinais e extra intestinais (6)

O reconhecimento continuo pelas APC do complexo gliadina-tTG2 como estímulo imunogênico acentua a resposta imunológica e pró-inflamatória, desencadeando a resposta autoimune observada na DC (HUSBY et al., 2012). No entanto, em indivíduos saudáveis também se verifica o reconhecimento desses peptídeos quando apresentados pelo MHC de classe II originado do HLA DQ2/DQ8 (MOLBERG et al., 1997).

A DC é uma das doenças autoimunes mais bem elucidadas e uma das intolerâncias alimentarem permanentes mais comum entre os humanos, chegando a afetar pelo menos $1 \%$ da população ocidental (DUBÉ et al., 2005). Por vários motivos, a DC é um excelente modelo para estudar os fatores genéticos que contribuem para o desenvolvimento de desordens imunomediadas. Uma das razões é ter um fator ambiental desencadeador bem conhecido, o glúten. Outra, decorre do fato de ser uma doença autoimune com predisposição genética bem descrita associada a alelos HLA- 
DQ2/DQ8 do MHC, documentado há mais de 40 anos em trabalho publicado por Keuning e colaboradores em 1976. Outro motivo, é a existência do envolvimento de outros genes, não MHC, compartilhados com outras doenças autoimunes e, a elevada incidência de outras doenças imunológicas relatadas tanto em doentes celíacos quanto em familiares, em que a resposta inata e adaptativa exercem papel fundamental (ZHERNAKOVA et al., 2009).

A DC é considerada ainda, uma doença multifatorial, causada pela interação de diferentes fatores genéticos que atuam em consonância com efeitos não-genéticos, uma vez que indivíduos não celíacos também possuem tais alelos, sugerindo que mecanismos complementares adicionais são necessários para o desenvolvimento da doença (MAIURI et al., 2003).

Similarmente a outras doenças autoimunes, a DC é uma desordem poligênica e o gene do MHC é o fator genético mais importante. A maioria dos doentes celíacos carregam uma variância genética específica de HLA-DQ2 (DQA1*05:01, DQB1*02:01, conhecida com DQ2.5) e, aqueles que não são HLA-DQ2.5 quase sempre carregam a variância HLA-DQ8 (DQA1*03, DQB1*03:02) ou, outra variância de HLA-DQ2 (DQA1*02:01, DQB1*02:02), conhecida como DQ2.2 (Dubé et al., 2005). Uma vez que todos os doentes celíacos carregam variações específicas de HLA, este fator pode ser considerado necessário para o diagnóstico da DC, mas não suficiente, para o desenvolvimento da DC (SOLLID \& JABRI, 2013).

Recentemente, estudos baseados em Genome Wide Association Studies (GWAS) permitiram a identificação de Single-Nucleotide Polymorphisms (SNPs) em cada gene do genoma humano associado a uma via metabólica celular ou a um fenótipo específico como, por exemplo, a DC. De modo geral, GWAS testa centenas de milhares de SNPs ao longo de todo o genoma humano de pacientes e pareia com grupo étnico de controle (CHANOCK et al., 2007).

Esses SNPs frequentemente afetam o reconhecimento de fatores de transcrição, resultando em diferenças na expressão de genes regulatórios compartilhados com outras doenças autoimunes. Após os estudos de GWAS, foi possível verificar, por análise de immunochip, que vários genes não MHC têm sido relacionados como fatores de susceptibilidade para DC. Até então, 39 loci com 57 sinais de associações independentes foram descritas, contribuindo com $14 \%$ da variância genética para DC (TRYNKA et al., 2012). 
Muitas dessas variâncias genéticas são compartilhadas com outras doenças autoimunes, tais como, Diabetes mellitus Tipo 1 e Artrite Reumatoide (GUTIERREZACHURY et al., 2016). Depois dos estudos de GWAS, uma vez evidenciadas correlação com vias metabólicas e de resposta inflamatórias compartilhadas entre DC e outras doenças autoimunes, novas estratégias que façam uso de diferentes modelos celulares podem ser aplicadas para a DC (KUMAR et al., 2012).

\subsection{O Papel da gliadina na Doença Celíaca}

O glúten é a proteína de estoque energético encontrada em grão do trigo, centeio, cevada e aveia. O trigo é uma espécie hexaplóide e alguns genes que codificam o glúten são originários de loci duplicados, dessa forma, em uma única variedade de trigo existem mais de uma centena de proteínas de glúten diferentes, o que justifica a enorme quantidade de epítopos de células T-CD4 responsivos aos peptídeos de gliadina (VACCINO et al., 2009; BALAKIREVA \& ZAMYATNIN 2016).

A proteína do glúten apresenta grande quantidade de resíduos de aminoácido de prolaminas (glutamina e prolina) em sua estrutura primária. De acordo com a solubilidade dessas prolaminas, a proteína do glúten pode ser dividida em dois grupos: 1) solúveis em álcool, conhecidas como gliadina e; 2) insolúveis em álcool, ou solúveis em diluições ácidas e básicas, conhecidas como glutenina (WIESER, 2007).

A gliadina é uma proteína álcool-solúvel, de $30 \mathrm{kDa}$, particularmente rica em resíduos de glutamina e de prolina, que estão contidos em sequências poliglutamínicas (ANG et al., 2010). A gliadina é representada como uma cadeia única de polipetídeos, que podem ser divididos em quatro grupos distintos: $\alpha-, \beta-, \gamma-$ e $\omega$-gliadina (WIESER, 2007). O domínio $N$-terminal da $\alpha$-gliadina contém o fragmento mais caracterizado como imunogênico, o fragmento 33-mer (figura 3). $\mathrm{O}$ fragmento peptídico 33-mer da $\alpha$ -

gliadina contém seis epítopos significativos para a patogênese da DC (OZUNA et al., 2015). 


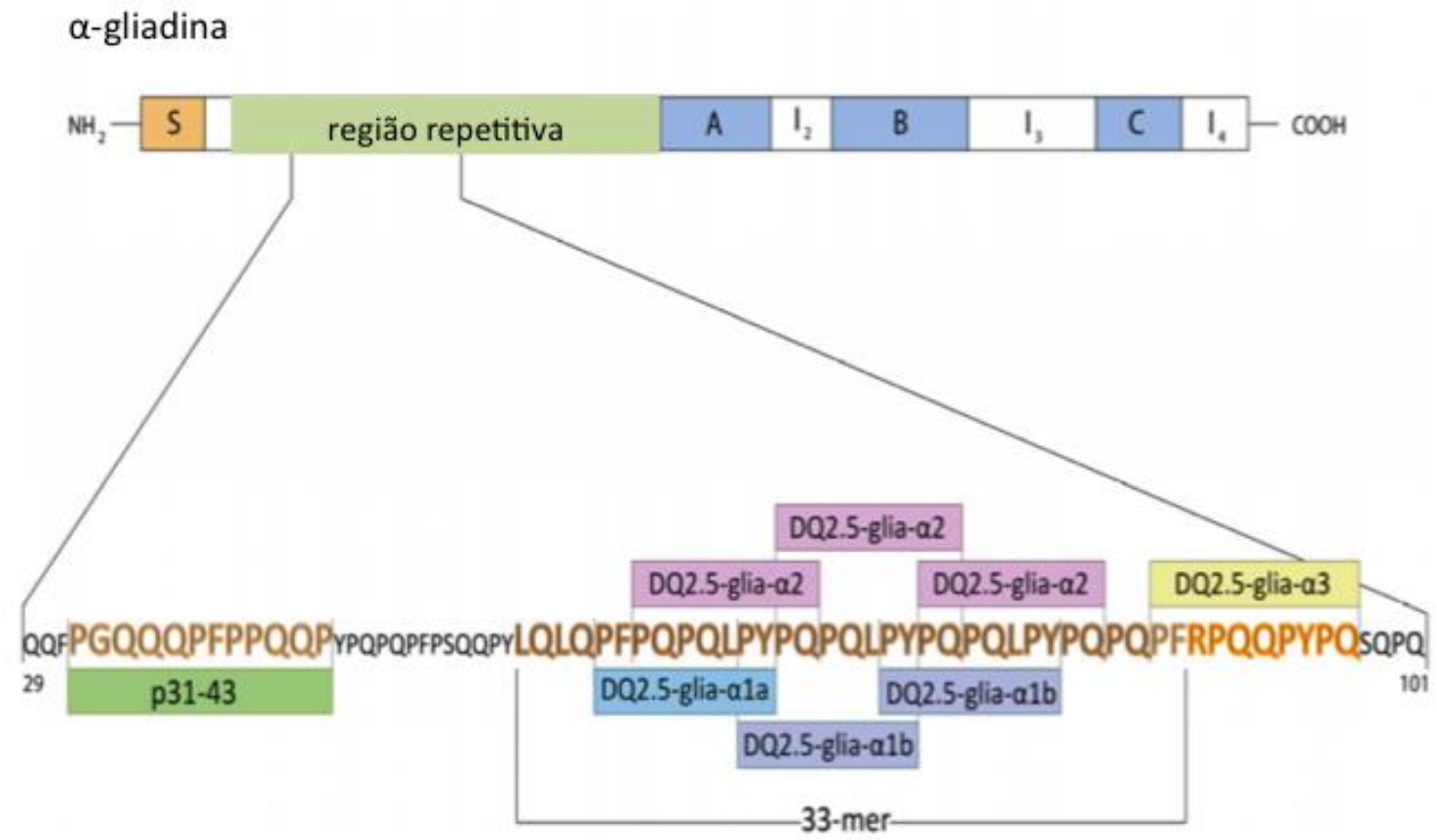

Figura 3 - Sequência proteica de $\alpha$-gliadina

Fragmento $\alpha$-gliadina contém a região repetitiva de resíduos de prolina e glutamina em sua porção N-terminal onde está contido os fragmentos imunogênicos p31-43 e 33-mer, resposívos a epítopos ligantes dos heterodímeros HLA-DQ

Adaptado de BALAKIREVA \& ZAMYATNIN, 2016

As sequências de prolina influenciam no direcionamento e especificidade da ação da enzima tTG2, que reconhece os resíduos de glutamina ao longo das sequências polipeptídicas repetitivas (FLECKENSTEIN et al., 2002). Os resíduos de glutaminas sofrem processo de desamidação por meio da ação catalizadora da enzima transglutaminase tecidual do tipo 2 (tTG2) que, na presença de cálcio, converte os resíduos de glutamina em resíduos de ácido glutâmico, como verificado na figura 4 (ANG et al., 2010; FLECKENSTEIN et al., 2002). O fragmento 33-mer atinge a lâmina própria e é desamidado pela tTG2 e apresentado por células dendriticas para as células $\mathrm{T}$, e junto com o fragmento p31-43 ativam a resposta imune inata e adaptativa da DC (BARONE et al., 2011). 


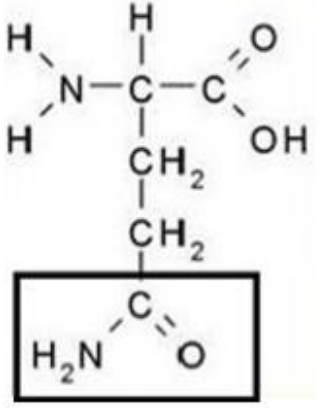

Glutamina

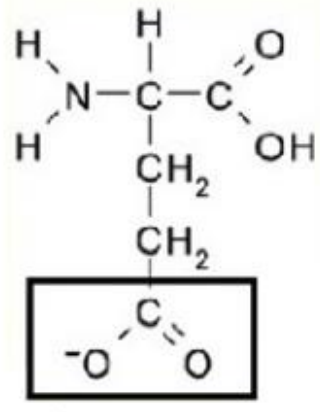

Ácido glutâmico

Figura 4 - Desamidação promovida pela enzima tTG2

tTG2 na presença de cálcio converte resíduos de glutamina em ácido glutâmico. A carga negativa do ácido glutâmico aumenta a afinidade da tTG2 pela gliadina e forma o complexo gliadina + tTG2. A carga negativa do ácido glutâmico também aumenta a afinidade pela molécula HLA-DQ

Adaptado de ABADIE et al., 2011

\subsection{Efeito imunogênico e citotóxico gerado pela gliadina}

Existe um consenso de que o fragmento 33mer é o mais imunogênico da porção $\alpha$-gliadina, por ser resistente a digestão pelas enzimas gástricas, além de conter a maioria dos epítopos reconhecidos pelas células T-CD4. Peptídeos desamidados pela enzima tTG2 são predominantemente reconhecidos por linfócitos intraepiteliais. Os peptídeos p57-68 e p62-75 foram identificados como imunodominantes, ou seja, capazes de ativar a resposta imune adaptativa via reconhecimento pelas células T-CD4. Os peptídeos p31-49, p31-43, p44-55 e p62-75 também são reconhecidos e ativam a resposta imune inata pela ativação de citocinas pró-inflamatórias (SHAN et al., 2002).

O dano na mucosa intestinal do doente celíaco é mediado pela inflamação gerada tanto pela resposta imune adaptativa quanto pela resposta imune inata. Os peptídeos fragmentados de gliadina são altamente imunogênicos para os doentes celíacos e a cascata imuno-inflamatória desencadeada é disparada, principalmente, por peptídeos presentes no fragmento 33-mer da gliadina (ANG et al., 2010; RAUHAVIRTA et al., 2011). Entretanto, é feita uma distinção entre o efeito imunogênico e o efeito tóxico dos peptídeos de gliadina (Figura 5). 


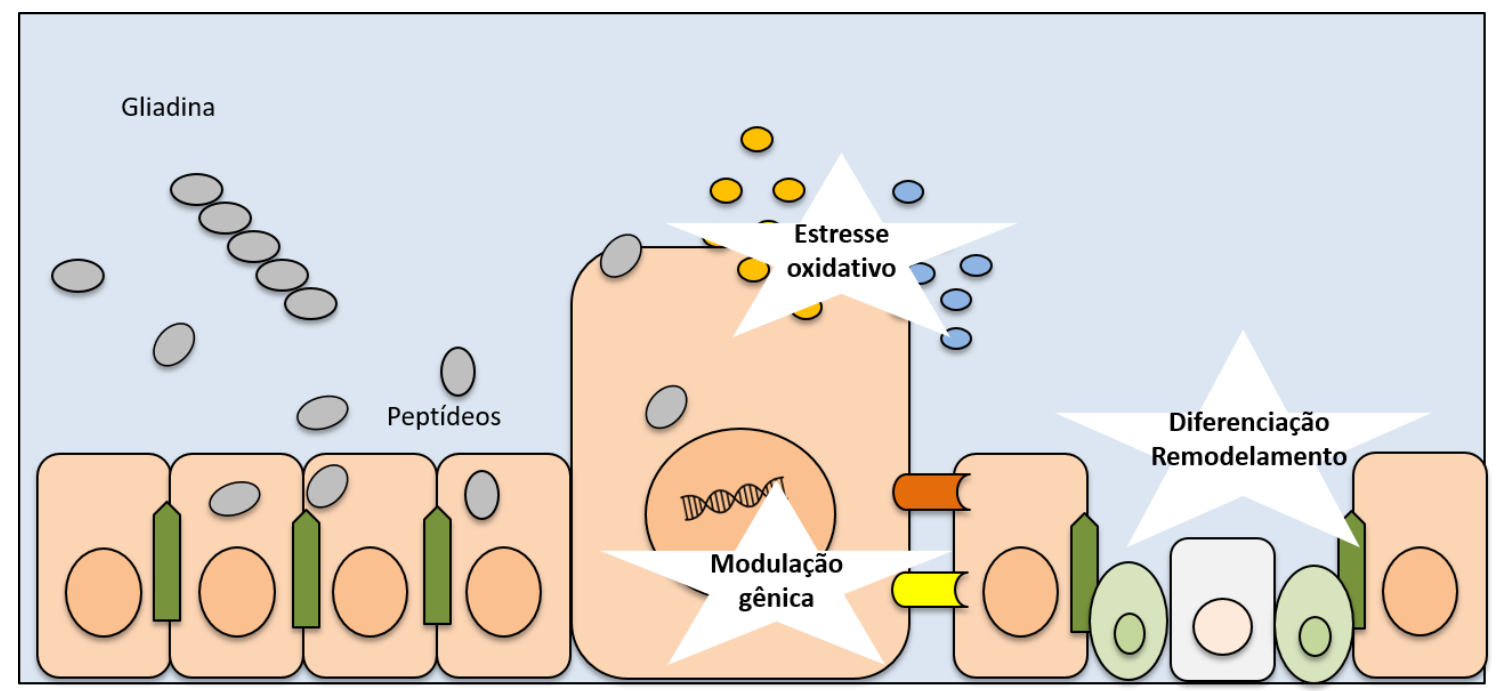

Figura 5 - Dano no tecido epitelial causado pelo efeito tóxico e imunogênico de peptídeos de gliadina na DC

Peptídeos tóxicos induzem a modulação gênica de citocinas inflamatórias, estresse oxidativo e remodelamento e apoptose da barreira epitelial intestinal. Esses efeitos são mediados pelo aumento no estresse oxidativo induzido pela gliadina no enterócito. Tais alterações levam a despareamento das junções TJ da barreira epitelial intestinal e aumento da permeabilidade. Como consequência direta mais peptídeos de gliadina passam pela barreira epitelial, causando maior ativação da resposta imune, contribuindo com o dano celular e atrofia das vilosidades intestinais na DC

Peptídeos imunogênicos contem sequências que estimulam o reconhecimento via HLA-DQ2/DQ8, o que induz a resposta imune adaptativa derivada de clones de células T-CD4. Por exemplo, foi observado que o peptídeo p57-68 é parcialmente degradado pelas peptidases presentes na borda em escova do epitélio intestinal, como observado em biópsias de indivíduos saudáveis, mas não em biópsias de doentes celíacos, transpondo a barreira epitelial e iniciando a resposta imune adaptativa neste último grupo (MOLBERG et al., 1997). Contudo, quando o peptídeo p57-68 atravessa as células epiteliais pela via transepitelial, ele é completamente degradado tanto em cultura celular de biópsias de indivíduos saudáveis quanto em cultura celular de biópsias de pacientes celíacos (MATYSIAK-BUDNIK et al., 2008).

Os peptídeos tóxicos de gliadina p31-43, p31-49 e p44-55 são resistentes contra a degradação pelas peptidases da borda em escova em células epiteliais de biópsias de doentes celíacos, mas não de indivíduos saudáveis. Ainda assim, esses peptídeos foram capazes de atravessar a barreira epitelial das células de biópsias de pacientes celíacos e não das células de indivíduos saudáveis (MATYSIAK-BUDNIK et al., 2008; GIOVANNINI et al., 2000). 
O p31-43 evoca uma resposta imune inata no enterócito, via IL-15, interferindo na maturação das vesículas endocíticas, reduzindo, consequentemente, a degradação de receptores do fator de crescimento epidermal (EGFR). Dessa forma o receptor EGFR é mantido ativado por mais tempo, o que resulta no aumento do sinal para proliferação celular e modificações na actina dos enterócitos e de outras linhagens celulares, além de induzir a apoptose celular em cultura de células de biópsias intestinais de doentes celíacos (BARONE et al., 2010).

Quando acumulado nos lisossomos das células epiteliais o peptídeo p31-43 provoca um aumento nas condições envolvidas no processo de estresse oxidativo elevando os níveis de radicais livres presentes nas células, principalmente Espécies Reativas do Oxigênio (ROS) e Espécies Reativas do Nitrogênio (RNS). O aumento do estresse oxidativo pode induzir alterações na morfologia dos enterócitos e aumentar a proliferação celular, e consequente apoptose celular (GIOVANNINI et al., 2000; RIVABENE et al., 1999).

As espécies reativas do oxigênio (ROS) e espécies reativas do nitrogênio (RNS) podem ser geradas a partir de várias reações intracelulares, bem como podem atuar como segundos-mensageiros participando da homeostase dos tecidos orgânicos. Quando na presença de estímulos inflamatórios, é possível verificar um aumento nas concentrações destas moléculas (LAPARRA et al., 2008). Durante este processo, ROS e RNS passam a atuar de maneira deletéria, com comportamento citotóxico, reagindo inespecificamente com as proteínas, lipídeos e ácidos nucleicos, com potencial de causar danos irreversíveis. O processo de estresse oxidativo instala-se com a elevação dos níveis destas espécies reativas e com a redução da capacidade de enzimas citoplasmáticas de neutralizar este evento (RODRÍGUEZ-RAMIRO et al., 2011).

O óxido nítrico (NO) produzido no processo de estresse oxidativo e está envolvido na regulação de diversos mecanismos fisiopatológicos e é sintetizado pela enzima óxido nítrico sintetase (NOS) que possui três isoformas; NOS neural (NOS-1 ou nNOS), NOS induzível (NOS-2 ou iNOS) e NOS endotelial (NOS-3 ou eNOS) (KORHONEN et al., 2005). A iNOS é a isoforma que responde a estímulos inflamatórios diversos, desencadeando a produção de NO, e é observada diferentemente expressa em diversos modelos celulares quando desafiados com peptídeos de gliadina (DE STEFANO et al., 2007). Quando em grandes concentrações, pode se comportar 
como radical livre e gerar efeitos citotóxicos, principalmente durante o desenvolvimento de processos inflamatórios (KORHONEN et al., 2005).

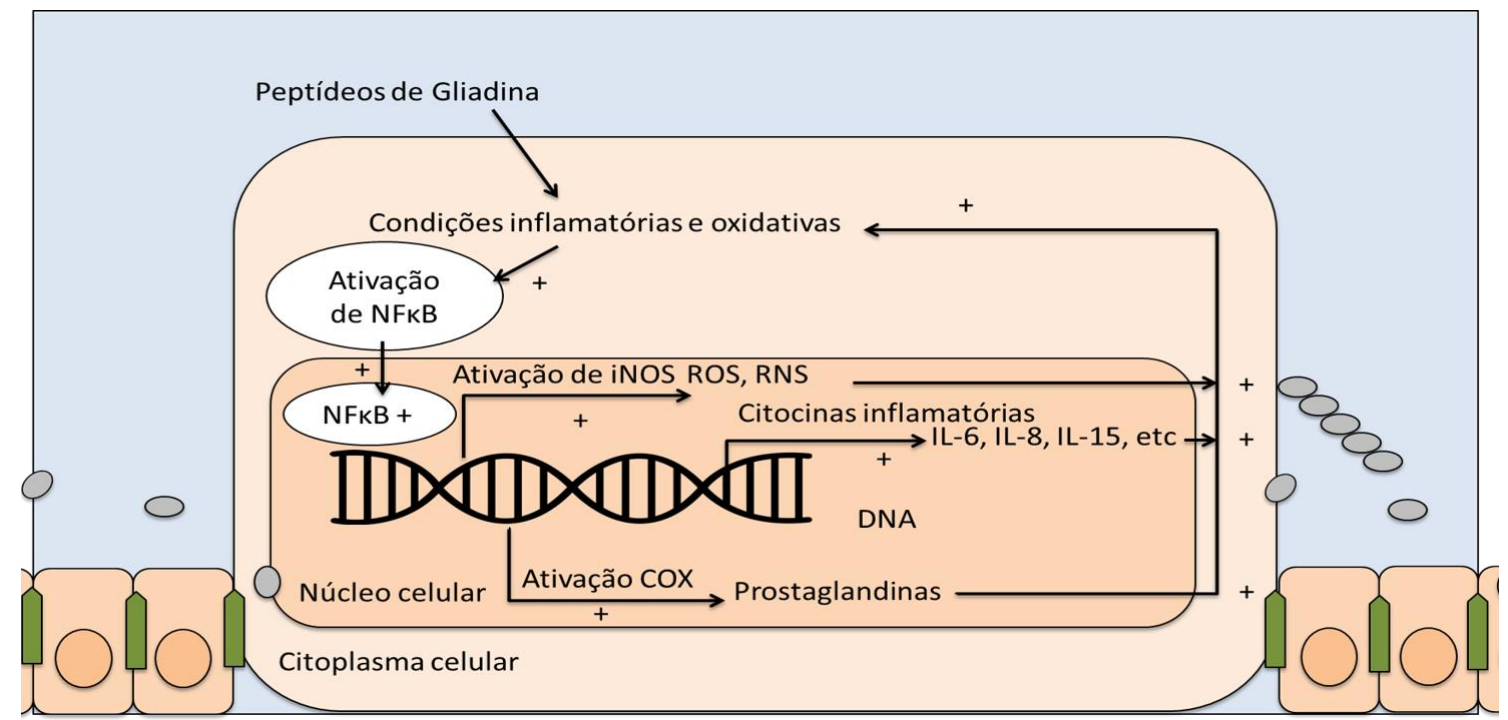

Figura 6 - Representação da ativação da via NFkB

Desequilíbrio na homeostase oxidativa do entererócito causado pela presença de gliadina e produção de transcritos gênicos de estresse oxidativo e de expressão de citocinas inflamatórias pela ativação da via NFkB. Deslocamento de citocinas pró-inflamatórias e de ativadores de estresse oxidativo para o citoplasma, reativando a via NFkB. Símbolo (+) representa ativação da via

A atividade citotóxica gerada pela gliadina na DC é desencadeada pela expressão de citocinas com atividade pró-inflamatórias, como por exemplo as interleucinas: IL-1, IL-6, IL-8, IL-15 entre outras (figura 6). Essa citocinas são ativadas

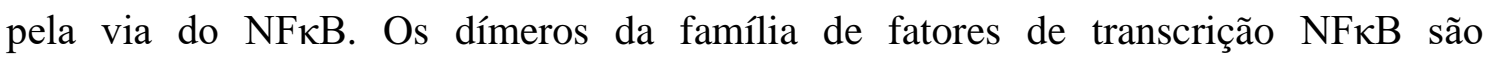
mediadores da resposta inflamatória celular (HOFFMANN \& BALTIMORE 2006). A ativação do NFאB é associada a doenças inflamatórias crônicas, como por exemplo, artrite reumatoide, asma, cardiopatias e múltiplas formas de cânceres (BARNES \& KARIN 1997; LABERGE et al., 2005). Os mecanismos que levam à disfunção do NFкB e exacerbação da resposta inflamatória nos enterócitos podem ser alvos de estudos para o desenvolvimento de novos fármacos com ação anti-inflamatórias (TERGAONKAR 2006).

O NFкB está localizado no citoplasma celular, em sua forma latente, acoplado ao seu inibidor IкB (BASAK et al., 2007). Sua ativação dá-se por intermédio da ação de respostas biológicas que envolvem a participação de receptores de membrana (receptor de fatores de necrose tumoral - TNFR, superfamília de receptores de Interleucina-1 do 
tipo toll-like -TLR e receptor de Interleucina-1 - IL-1R), sinais extracelulares (metabólitos, proteínas, bactérias) e por estresse oxidativo. Estes eventos intracelulares ocasionam a fosforilação e degradação dos inibidores $\mathrm{I} \kappa \mathrm{B}$, que possibilitam a ativação do NFкB (YAMAMOTO \& GAYNOR 2004). Uma vez livre de seu inibidor, NFкB transloca-se livremente para o núcleo da célula, onde cada dímero, de forma independente, acopla-se a elementos responsivos (RE) no DNA e ativa a expressão gênica de citocinas pró-inflamatórias (HOFFMANN et al., 2003). A ativação do NFאB também promove a expressão gênica de seus dímeros e inibidores, propiciando seu controle por feedback positivo e negativo (BASAK et al., 2007; MITCHELL et al., 2016).

NFאB é responsável pela transcrição de genes fundamentais que codificam várias citocinas pró-inflamatórias. Estudos tem mostrado que NFkB é mediador de IL15, que prejudica a ação das junções TJ nas células epiteliais diminuindo a expressão de ocludina e aumentando a expressão de zonulina nessas células, fenômeno comumente relatado em doentes celíacos (SAPONE et al., 2011).

Alterações na homeostasia observada nos enterócitos, induzidas pela gliadina, iniciam e/ou intensificam a ativação do fator de transcrição nuclear kappa B (NFkB). Quando NFкB está ativado promove a transcrição de genes pró-inflamatórios e a ativação da ciclooxigenase (COX) com posterior expressão de prostaglandinas, tromboxanos e leucotrienos. Promove também a ativação da via de iNOS, com consequente produção de níveis elevados de metabólitos de NO, que contribuem ainda mais com o estresse oxidativo (DE STEFANO et al., 2007; MAIURI et al., 2003).

\subsection{Células Caco-2 como modelo de estudo para Doença Celíaca}

A patogênese da DC inicia após a digestão incompleta dos peptídeos derivados da gliadina que entram em contato com as células da mucosa intestinal. Em pacientes celíacos as células epiteliais proliferam-se rapidamente sem diferenciarem-se em enterócitos, sua apoptose é aumentada, a integridade das junções epiteliais é comprometida e os peptídeos de gliadina ganham acesso a lâmina própria. Apesar de numerosas tentativas de desenvolvimento de um modelo animal que reproduzisse todos os aspectos morfológicos e sorológicos da $\mathrm{DC}$, tal alternativa ainda não foi completamente estabelecida. Entretanto, o uso de diversas abordagens in vitro e cultivo 
de biópsias de doentes celíacos vem gerando grande conhecimento a respeito de sua patogênese e tornado possível diferentes abordagens de estudo para DC, porém seu uso implica em questionamentos éticos quanto ao uso de seres humanos para a experimentação científica, além de que tal cultura não se mantém viável por muito tempo (MARIETTA et al., 2009) .

Dentre os modelos celulares in vitro para o estudo da DC, as células mais utilizadas são do tipo T84, derivada de metástase pulmonar de câncer de cólon, e células Caco-2, obtidas de células bem diferenciadas de adenocarcinoma de cólon humano (LINDFORS et al., 2012). As células Caco-2 quando atingem confluência diferenciamse espontaneamente. Quando em cultura tais células são polarizadas e possuem morfologia de enterócitos com a superfície apical coberta por microvilosidades (BOLTE et al., 1998). Em monocamada as células são unidas por junções apicais complexas que incluem junções TJ e desmossomos. Culturas em pós-confluência expressam sucrase, isomaltase, fosfatase alcalina e aminopeptidase $\mathrm{N}$, e enzimas típicas de enterócitos diferenciados (LINDFORS et al., 2012). Quando desafiadas com glúten, Caco-2 expressa IFN- $\gamma$ e TNF- $\alpha$, citocinas relacionadas no aumento de expressão de proteínas das junções TJ, como por exemplo, zonulina e ocludina, aumentando a permeabilidade celular (FASANO et al., 2011). Todas essas características tornam as células Caco-2 a linhagem mais utilizada para estudos de modelos de barreira epitelial intestinal e a mais relatada em estudos de DC. 


\section{JUSTIFICATIVA}

O diagnóstico e tratamento da DC estão atualmente bem esclarecidos, a sua patogênese ainda apresenta muitas lacunas a serem preenchidas. $\mathrm{Na}$ tentativa de esclarecer de forma mais ampla a resposta imunológica na DC, numerosos estudos têm lançado mão de novas estratégias, principalmente nos campos da genética e da biologia molecular, enfocando os mecanismos de interação do antígeno com a célula intestinal.

O entendimento dessa interação gênica e das suas bases moleculares tem sido essencial para o melhor conhecimento dos mecanismos patogênicos das várias doenças autoimunes, bem como na definição de alvos terapêuticos mais eficientes. Embora as formas de entrada do peptídeo no epitélio tenham sido elucidadas, o mecanismo pelos quais os peptídeos de gliadina modulam a biologia da célula e iniciam a resposta imune e inflamatória não estão completamente esclarecidos. Ainda não se tem respostas de quais são as alterações celulares decorrentes desse primeiro evento de interação ocasionados pela gliadina.

Considerando que o evento inicial da resposta imunológica na DC, é a interação entre a gliadina e seus peptídeos e a célula epitelial intestinal, e que os eventos decorrentes dessa interação ainda não estão bem esclarecidos, o presente trabalho propõe observar os efeitos da interação, através do estudo da expressão de genes envolvidos neste mecanismo. Esta análise poderá, desta forma, auxiliar no melhor entendimento da patogênese da doença celíaca em seu estágio inicial de instalação. 


\section{OBJETIVOS}

\subsection{Objetivo principal}

Entender o evento inicial na patogênese da doença celíaca em células Caco-2 modelo in vitro de barreira epitelial intestinal.

\subsection{Objetivos secundários}

Analisar o impacto da gliadina e seus peptídeos na modulação de transcritos gênicos mediadores da resposta imune e inflamatória nas células Caco-2.

Dosar citocinas e óxido nítrico secretados no sobrenadante da cultura de células Caco-2 em resposta a presença da gliadina e seus peptídeos. 


\section{MATERIAIS E MÉTODOS}

Todos os experimentos deste trabalho foram elaborados e conduzidos no Laboratório Interdisciplinar de Biociências (LabIBC), Laboratório de Pesquisas em Doença Celíaca (LABDC) e Laboratório de Pesquisas em Doenças Imunogenéticas e Crônico-degenerativas (LADIC) da Faculdade de Medicina (FM), Universidade de Brasília (UnB), no período de janeiro de 2012 a outubro de 2016.

\subsection{Fase Analítica I}

Antes de iniciar os experimentos pretendidos para este estudo, foram necessários uma série de ensaios iniciais, elaborados para estabelecer a concentração celular a ser empregada nos ensaios posteriormente, para definir as concentrações ideais de estímulos a serem utilizados, bem como ensaios para otimização dos primers escolhidos para o estudo da técnica de q-PCR. Todos estes ensaios foram incluídos nesta etapa analítica.

\subsubsection{Cultura in vitro das Células Caco-2}

Caco-2 são células de linhagem epitelial obtidas a partir células de câncer de cólon e é o modelo in vitro mais aceito e padronizado para estudo de epitélio intestinal humano com seu uso reconhecido pelo Food and Drug Administration (FDA). As características da linhagem celular e orientações de cultivo estão descritas pela American Type Culture Collection ATCC® HTB-37 ${ }^{\text {TM }}$ (ATCC, 2013).

As células Caco-2, também chamadas HTB-37, foram adquiridas do banco de células do Instituto Adolfo Lutz, e foram recuperadas conforme orientações e protocolos da ATCC, com padrões normais de crescimento, de confluência e morfologia. Após crescimento adequado, quantidade suficiente de células Caco-2 permaneceram em cultura de manutenção para uso nos estudos previstos pelo laboratório.

A cultura celular foi mantida em garrafas de cultura de células de $75 \mathrm{~cm}^{2}$ contendo meio Eagle Modificado por Dulbecco (DMEM) com $4.5 \mathrm{~g} / \mathrm{L}$ de glucose, 2 mM L-glutamina, sem piruvato de sódio (DMEM high glucose ref 11965-092 GIBCO, 
Life Technologies); suplementado com piruvato de sódio $200 \mathrm{mM}$ (SIGMA-Aldrich); $100 \mathrm{U} / \mathrm{mL}$ de penicilina-estreptomicina (SIGMA-Aldrich); $1 \%$ aminoácidos não essenciais; 25 mM de HEPES (Ácido Etanosulfônico 4-2-Hidroetil Piperazina-1, SIGMA-Aldrich) e $20 \%$ de Soro Fetal Bovino (SFB GIBCO, Life Technologies) inativado à $56{ }^{\circ} \mathrm{C}$ por 1 hora, que foi denominado meio DMEM completo. A cultura foi mantida em estufa a $37{ }^{\circ} \mathrm{C}$ com $5 \%$ de $\mathrm{CO}_{2}$ e $95 \%$ de umidade com trocas regulares do meio de cultura $(8-10 \mathrm{~mL})$, a cada 3 a 4 dias. $\mathrm{O}$ subcultivo foi realizado quando as culturas atingiam taxa de confluência de $80 \%$, eram então descoladas da superfície do frasco utilizando tripsina a $0,05 \%$ contendo $0,53 \mathrm{mM}$ EDTA (GIBCO, Life Technologies) e semeadas na concentração $2 \times 10^{6}$ células para um novo frasco de 75 $\mathrm{cm}^{2}$.

\subsubsection{Estímulos utilizados nos estudo}

\subsubsection{Lipopolissacarídeo(LPS) de Escherichia coli}

O lipopolissacarídeo (LPS) utilizado neste estudo foi o extraído da Escherichia coli, adquirido junto a Sigma-Aldrich código 2880 (St. Louis, Missouri, EUA). O LPS é um componente constitutivo bacteriano que causa resposta inflamatória quando em contato com células de outras origens, desencadeando a produção de óxido nítrico (NO) e regulando a expressão da enzima óxido nítrico sintetase induzível (iNOS) principalmente pelas vias de sinalização MAPKs e $N F \kappa B$ (MANCINO \& LAWRENCE, 2010). O LPS foi diluído em água ultra pura e utilizado na concentração de $1 \mu \mathrm{g} / \mathrm{mL}$ de meio de cultura.

\subsubsection{Gliadina intacta e peptídeos de gliadina}

A gliadina utilizada no presente estudo foi adquirida junto a Sigma-Aldrich com código G5004 (St. Louis, Missouri, EUA), certificada e com grau de pureza superior a $95 \%$. Uma vez que a gliadina é solúvel em álcool, $1 \mathrm{~g}$ de gliadina foi ressuspendida em $50 \mathrm{~mL}$ de etanol $60 \%$ e aquecida por 8 horas a $37{ }^{\circ} \mathrm{C}$ e submetida a agitação mecânica até completa diluição, resultando em uma concentração de 20 $\mathrm{mg} / \mathrm{mL}$. Dessa solução foi transferido $2 \mathrm{~mL}$ para um novo tubo e diluído em $4 \mathrm{~mL}$ de etanol $60 \%$ e, ao fim, foram adicionados mais $4 \mathrm{ml}$ de PBS 1 X, para a obtenção de 
uma solução com concentração de $4 \mathrm{mg} / \mathrm{mL}$. Dessa solução foi retirado $1 \mathrm{~mL}$ e adicionado a $4 \mathrm{~mL}$ de PBS 1x (solução de uso).

Os peptídeos derivados do fragmento 33-mer $\alpha$-9-gliadina foram selecionados a partir dos artigos publicados por Salky e colaboradores (SALKY et al., 2006) e Rauhavirta e colaboradores (RAUHAVIRTA et al., 2011) e estão divididos em: nãodesamidados (P56-88; P57-68; P69-82; P31-43) e desamidados (P57-68E65 e P6982E72), conforme Tabela 1. As sequências dos peptídeos foram sintetizadas por GeneScript (Piscataway, USA) que, de acordo com metodologia própria, que confirmou a identidade de cada peptídeo por espectrometria de massa, o grau de pureza $\geq 95 \%$ para cada peptídeo empregando reverse-phase High Performance Liquid Chromatography (HPLC). Após obtenção dos peptídeos, os mesmos foram diluídos em água ultrapura, ph 7.0, conforme orientação do fabricante, para uma concentração final de $25 \mu \mathrm{M}$ ou $0,5 \mathrm{mg} / \mathrm{mL}$ de meio de cultura empregado nos experimentos (adaptado de RAUHAVIRTA et al., 2011).

Tabela 1 - Sequência dos peptídeos de gliadina sintetizados

\begin{tabular}{|c|c|c|c|}
\hline PEPTÍDEO & FRAGMENTO & SEQUENNCIA & REFERÊNCIA \\
\hline $\mathrm{P} 1$ & $\begin{array}{c}\text { 33mer } \alpha-9 \text {-gliadin }(56- \\
88)\end{array}$ & $\begin{array}{c}\text { LQLQPFPQPQLPYPQPQLPYP } \\
\text { QPQLPYPQPQPF }\end{array}$ & (Sakly et al., 2006) \\
\hline $\mathrm{P} 2$ & $\begin{array}{l}\alpha-9-\operatorname{gliadin}(57-68) \mathrm{N}- \\
\text { terminal }\end{array}$ & QLQPFPQPQLPY & $\begin{array}{c}\text { (Rauhavirta et al., } \\
\text { 2011) }\end{array}$ \\
\hline P3 & $\begin{array}{l}\alpha-9 \text {-gliadin }(69-82) \mathrm{C}- \\
\text { terminal }\end{array}$ & PQPQLPYPQPQLPY & (Sakly et al., 2006) \\
\hline $\mathrm{P} 4$ & $\begin{array}{l}\alpha-9-\text { gliadin }(31-43) \mathrm{C}- \\
\text { terminal }\end{array}$ & LGQQQPFPPQQPY & $\begin{array}{c}\text { (Rauhavirta et al., } \\
\text { 2011) }\end{array}$ \\
\hline P5 & $\begin{array}{c}\alpha-9 \text {-gliadin }\left(57-68 \mathrm{E}_{65}\right) \\
\text { N-terminal Desamidado }\end{array}$ & QLQPFPQPELPY & $\begin{array}{c}\text { (Rauhavirta et al., } \\
\text { 2011) }\end{array}$ \\
\hline P6 & $\begin{array}{c}\alpha-9 \text {-gliadin }\left(69-82 \mathrm{E}_{72}\right) \\
\text { C-terminal Desamidado }\end{array}$ & PQPELPYPQPQLPY & (Sakly et al., 2006) \\
\hline
\end{tabular}

\subsubsection{Ensaio de viabilidade celular}

Para avaliar a citotoxicidade das soluções de LPS, gliadina e seus peptídeos, nas análises in vitro, foi utilizado o método colorimétrico de captação do corante Tetrazólio WST-8. Este ensaio consiste na capacidade da enzima mitocondrial desidrogenase succínica, presente somente em células viáveis, em clivar o sal monossódico de tetrazólio WST-8 [2-(2-metoxi-4-nitrofenil)-3-(4-nitrofenil)-5-(2,4-dissulfofenil) 2Htetrazólio]. Esta clivagem resulta na produção de cristais de formazan violeta presentes 
nas membranas celulares. O número de células viáveis é quantificado proporcionalmente à quantidade de formazan medida por espectrofotometria (JAFARAIN et al., 2014).

Para a realização do ensaio de citotoxicidade foi utilizado o sistema comercial Cell Couting kit- $8^{\circledR}$ (Sigma-Aldrich, Saint Louis - EUA) seguindo as instruções do fabricante. As células foram cultivadas em DMEM completo numa concentração de $1 \mathrm{x}$ $10^{5}$ células por poço em placas de cultura de 96 poços, contendo $200 \mu \mathrm{L}$ de meio DMEM completo até atingirem taxa de confluência de $80 \%$, por um período de 24 horas. Em seguida, o meio de cultura foi trocado por $100 \mu \mathrm{L}$ de meio DMEM incolor suplementado com $5 \%$ de SFB e $100 \mu \mathrm{L}$ de soluções de LPS, gliadina e seus peptídeos (P1 a P6) nas concentrações avaliadas, totalizando um volume total de $200 \mu \mathrm{L}$ por poço. Todas as amostras foram testadas em triplicata técnica.

Após a adição dos estímulos, as culturas celulares foram homogeneizadas e a placa foi novamente incubada nas mesmas condições descritas para o crescimento celular. Após 24h, o meio foi descartado e foi acrescentado em cada poço $100 \mu \mathrm{L}$ de meio DMEM incolor suplementado com 5\% de SFB, em seguida, foi adicionado $10 \mu \mathrm{L}$ de WST-8 em cada poço. Como referência de controle positivo de crescimento celular foram utilizados poços em que as células não foram submetidas a qualquer tratamento específico. Para o controle de morte celular foram avaliados os poços em que as células receberam tratamento com solução DMSO a $95 \%$ e etanol a $0,72 \%$. Por fim, o poço considerado branco de reagente continha apenas meio DMEM incolor em poços sem células.

Para a obtenção da viabilidade celular foi calculada a diferença entre o valor da leitura das células do tratamento em avaliação pelo valor da leitura dos poços que não possuíam células (branco). Este resultado foi multiplicado por 100 e dividido pela diferença da leitura das células que não receberam tratamento pela leitura do branco. $O$ produto obtido foi apresentado em porcentagem e definido como viabilidade celular. A fórmula aplicada nas células da planilha eletrônica para obtenção deste resultado foi:

Viabilidade celular $=\frac{\text { (absorbância da amostra }- \text { absorbância do branco) X 100 }}{\text { (absorbância das células não tratadas-absorbância do branco) }}$

Para avaliar a ausência de interação química entre os estímulos estudados e o reagente do kit WST-8, foram colocados em poços sem células as mesmas 
concentrações dos estímulos e adicionado o reagente WST-8. Após 6 horas de incubação com o WST-8, foi medida a absorbância das amostras em espectrofotômetro empregando comprimento de onda de $450 \mathrm{~nm}$.

\subsubsection{Ensaio de otimização da reação de q-PCR}

A utilização do SYBR Green demanda cuidadosa otimização do protocolo de reação de q-PCR para determinar o desempenho da reação a fim de permitir serem comparada com outras diferentes reações e condições de tratamentos. Para uma rigorosa avaliação diversos fatores são levados em consideração e somados para se obter maior precisão e confiança nos resultados.

Para confirmar a especificidade da reação por $S Y B R$, é preciso analisar a curva de melting e a concentração ideal de primers utilizados. Para cumprir este requisito foi realizado a padronização por matriz dos primers, ou titulação. Nesse experimento a matriz de primers forward e reverse combinaram três concentrações diferentes para cada primer $(300 \mu \mathrm{M}, 600 \mu \mathrm{M}$ e $900 \mu \mathrm{M})$ totalizando, nove diferentes combinações de concentrações dos primers forward e reverse (300/300, 300/600, 300/900, 600/300, 600/600, 600/900, 900/300, 900/600 e, 900/900 nM) A quantidade de primers presente na reação é importante para determinar se os reagentes contidos são usados uniformemente para que não falte e nem sobre reagentes, o que poderia gerar padrões inespecíficos de leitura.

A concentração ideal é aquela que apresenta um maior rendimento, ou seja, menor valor de threshold cycle $(\mathrm{Ct})$ e maior $\Delta \mathrm{RN}$ (LIVAK et al., 2001). Ainda com a titulação, é possível identificar a presença ou não de dímeros de primers e a especificidade da reação, apresentando uma única curva de melting. Na curva de melting é analisada a fluorescência das amostras em relação ao aumento de temperatura que permite a dissociação da fita dupla gerando uma temperatura de melting (Tm) onde cada amplicon possui apenas um Tm específico. Se a reação apresentar mais de um Tm é considerada inespecífica.

Os ensaios de concentração e de eficiência dos primers foram realizados em placas de 96 poços utilizando SYBR Green Maxima SYBR Green/Rox q-PCR mastermix (Thermo scientific, USA). A detecção da amplificação da fluorescência da molécula 
SYBR Green foi feita pelo sistema StepOne ${ }^{\circledR}$ Real-Time PCR System (Applied BioSystems - Life Technologies ${ }^{\mathrm{TM}}$, Carlsbad, USA).

Para a validação do método $2^{-\Delta \Delta C t}$ de quantificação relativa é necessário realizar o Ensaio de Eficiência da reação que garante que os resultados gerados serão precisos e confiáveis quando comparados entre si. A eficiência de amplificação é expressa em porcentagem gerada a partir da amplificação de uma diluição seriada de cDNA para geração de curva de dissociação e padrão. Para esse experimento foi necessário preparar grandes quantidade de cDNA de uma mesma amostra para ser diluída de forma seriada iniciando em 1:2 em 6 pontos de diluição, com concentrações de $100 \mathrm{ng}, 50 \mathrm{ng}, 25 \mathrm{ng}, 12,5 \mathrm{ng}, 6,25 \mathrm{ng}$ e 3,125 ng por reação de q-PCR.

Se um amplicon dobra em quantidade durante a fase geométrica de amplificação, então a eficiência dessa reação é de $100 \%$. Uma eficiência de $100 \%$ garante o aumento em 10-fold change de amplicon a cada 3.32 ciclos, durante fase exponencial de amplificação $\left(\log ^{2} 10=3.3219\right)$. Para um experimento de quantificação relativa ser válido, a eficiência de amplificação do gene alvo deve apresentar valores de eficiência entre 90 e $110 \%$ para ser eficiente na comparação entre valores e dizer o quanto um valor vai quantificar outro valor, conferindo uma boa confiança na correlação de dois valores (LIVAK et al., 2001).

\subsection{Fase analítica II}

Na fase analítica II, depois de estabelecido os parâmetros de cultura de célula, concentração dos reagentes e otimização do ensaio de q-PCR, foram realizados os experimentos de interação da cultura de células Caco-2 com os estímulos pretendidos por este trabalho, além de todas as reações de qPCR.

\subsubsection{Desenho experimental}

Para o presente estudo, $5 \times 10^{5}$ células foram transferidas para placas de cultura contendo 6 poços de $962 \mathrm{~mm}^{2}$ cada, com $3 \mathrm{~mL}$ de meio DMEM completo $20 \%$ de soro bovino fetal e mantidas em cultura até atingir $80 \%$ de confluência aproximadamente, com trocas regulares de meio. Atingida a confluência, foi então realizada troca para meio DMEM completo com $5 \%$ de soro bovino fetal, para controlar a taxa de crescimento celular, em seguida, as células foram mantidas em cultura na estufa a $37{ }^{\circ} \mathrm{C}$ 
com $5 \%$ de $\mathrm{CO}_{2}$ e $95 \%$ de umidade por mais 24 horas. Após este período a cultura estava pronta para as condições experimentais descritas a seguir.

Para avaliar o efeito da interação da gliadina e dos peptídeos em células Caco2, dois experimentos idênticos e independentes (replicata biológica) foram realizados. $\mathrm{O}$ tempo entre os experimentos foi de aproximadamente um mês. Para cada experimento 5 x $10^{5}$ células por poço foram cultivadas em 9 grupos distintos, sendo eles:

Tabela 2- Grupos experimentais e seus respectivos estímulos.

\begin{tabular}{c|l}
\hline Grupo & \multicolumn{1}{c}{ Estímulo } \\
\hline 1 & Não Tratado $(\mathrm{NT})-$ sem estímulo \\
\hline 2 & Estimulado com com $1 \mu \mathrm{g} / \mu \mathrm{L}$ de LPS \\
\hline 3 & Estimulado com $80 \mu \mathrm{g} / \mathrm{mL}$ de gliadina \\
\hline 4 & Estimulados com $25 \mu \mathrm{M}$ de P1 (p56-88) \\
\hline 5 & Estimulados com $25 \mu \mathrm{M}$ de Peptídeo P2 (p57-68) \\
\hline 6 & Estimulados com $25 \mu \mathrm{M}$ de Peptídeo P3 (p69-82) \\
\hline 7 & Estimulados com $25 \mu \mathrm{M}$ de Peptídeo P4 (p31-49) \\
\hline 8 & Estimulados com $25 \mu \mathrm{M}$ de Peptídeo P5 (p57-68 $\left.\mathrm{E}_{65}\right)$ \\
\hline 9 & Estimulados com $25 \mu \mathrm{M}$ de Peptídeo P6 (p69-82- $\left.\mathrm{E}_{72}\right)$ \\
\hline
\end{tabular}

Cada grupo foi cultivado em triplicada, sendo uma triplicata para cada tempo de 6, 24 e 48 horas. Ao final de cada tempo os $3 \mathrm{~mL}$ de sobrenadante de cada poço de culturas foram coletados, identificados e mantidos à - $20^{\circ} \mathrm{C}$ para posterior dosagem de óxido nítrico e citocinas. Em seguida foi adicionado ao poço $1 \mathrm{~mL}$ de Trizol (Ambion, Life Technologies) para lise das células até que todas se descolassem do frasco. O lisado foi transferido para um microtubo de $2 \mathrm{~mL}$ identificados e guardados a $-20{ }^{\circ} \mathrm{C}$ para posteriormente seguir com o protocolo de extração e purificação de RNA, como representado na figura 7. 


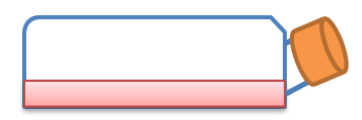

$6 \mathrm{~h}$

$24 \mathrm{~h}$

$48 \mathrm{~h}$
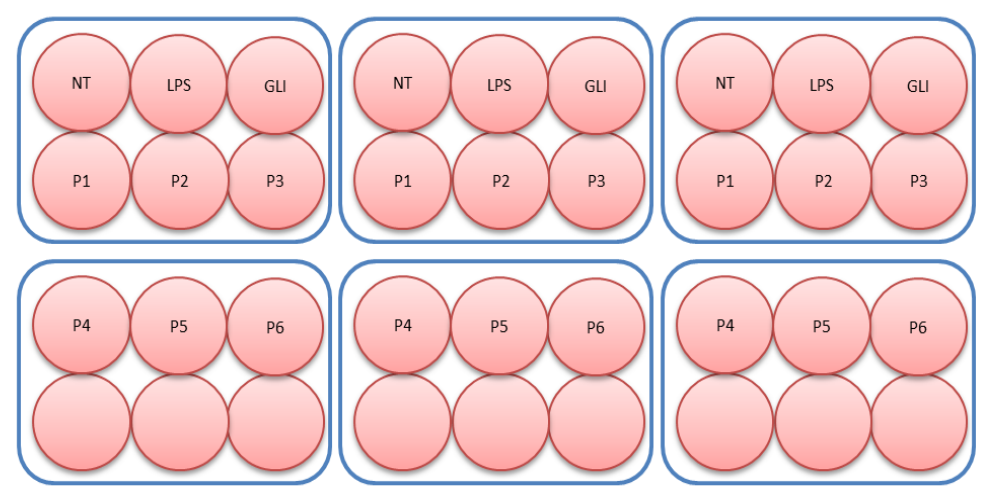

Óxido Nítrico Citocinas
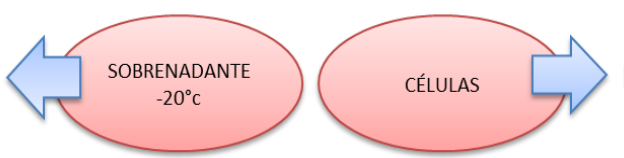

Extração RNA

Figura 7 - Delineamento experimental da interação dos peptídeos de gliadina em células Caco-2 NT (não tratado), LPS (lipopolissacarídeo), GLI (gliadina), P1-P6 (peptídeos de 1 a 6)

\subsubsection{Extração e purificação de RNA}

Para a extração e purificação de RNA, foi utilizado o Kit Direct-zolTM RNA Miniprep (R2051, Zymo Research, USA) seguindo as seguintes recomendações do fabricante. Após descongelar o microtubo contendo $1 \mathrm{~mL}$ de trizol com o lisado de células, foi adicionado $1 \mathrm{~mL}$ de etanol $95 \%$. O conteúdo foi homogeneizado e agitado vigorosamente por 15 segundos e transferido para a coluna de sílica para centrifugação a $11.000 \mathrm{~g}$ por 1 minuto. Após centrifugação, o filtrado foi coletado e descartado. Nessa etapa foi adicionada à coluna $400 \mu \mathrm{L}$ da solução de lavagem (RNA wash buffer) e uma nova centrifugação foi realizada a $12.000 \mathrm{~g}$ por 1 minuto. A coluna foi então transferida para novo tubo para dar início a purificação do RNA.

Para o processo de purificação do RNA foi adicionado à coluna $80 \mu \mathrm{L}$ de DNAse, então o tubo e coluna foram incubados a $37{ }^{\circ} \mathrm{C}$ por 15 minutos e após esse tempo o tubo foi centrifugado a $12.000 \mathrm{~g}$ por 30 segundos. No passo seguinte, foi adicionado à coluna $400 \mu \mathrm{L}$ de solução pré-lavagem (RNA pre-wash buffer) e realizouse uma nova centrifugação a $12.000 \mathrm{~g}$ por 1 minuto. $\mathrm{O}$ filtrado foi então descartado e repetiu-se esse passo novamente, para então ser adicionado à coluna $700 \mu \mathrm{L}$ de solução 
de lavagem (RNA wash buffer) e nova centrifugação a $12.000 \mathrm{~g}$ por 2 minutos. O filtrado foi descartado e em seguida centrifugou-se a coluna vazia na mesma velocidade e tempo. A coluna vazia foi transferida para novo microtubo livre de RNAse e recebeu a adição de $20 \mu \mathrm{L}$ de água ultra pura diretamente sobre a coluna de sílica (Invitrogen, Life technologies). Para a liberação do RNA purificado da coluna de sílica, uma nova centrifugação a $14.000 \mathrm{~g}$ por 2 minutos foi realizada. O filtrado contendo RNA foi coletado do fundo do tubo e transferido para novo tubo de $1,5 \mathrm{~mL}$ livre de DNAses e RNAses devidamente identificado para verificar pureza, integridade e quantificação do RNA.

A quantificação do RNA extraído foi determinada através de espectrofotômetro NanoVue ${ }^{\mathrm{TM}}$ (GE, Heathcare life sciences), que utiliza a leitura espectrofotométrica nas densidades ópticas (D.O.) 260 e $280 \mathrm{~nm}$. Quando a razão dessas densidades ópticas (A260/A280) foi superior a 1.9, o grau de pureza do RNA foi considerado adequado para a realização das análises posteriores. Depois de quantificado o RNA total foi estocado à $-80^{\circ} \mathrm{C}$ para posteriormente realizar a síntese do cDNA.

\subsubsection{Síntese de cDNA}

A síntese de cDNA foi realizada utilizando o Kit Highcapacity cDNA Reverse Transcription Kit (Applied Biosystems, USA) e as recomendações do fabricante seguidas na íntegra. Nas amostras, quantidades iguais de RNA $(2 \mu \mathrm{g})$ foram submetidas à transcrição reversa (RT). Uma vez sintetizado, a quantidade de RNA colocado na reação igual a quantidade de cDNA obtida após a reação. Para a síntese do cDNA, foi preparado mix contendo em cada reação: $10 \mu \mathrm{L}$ de RT Buffer $2 \mathrm{x} ; 1 \mu \mathrm{L}$ de enzima 20x; até $9 \mu \mathrm{L}$ de RNA e água nuclease-free q.s.p. A reação foi incubada em termociclador configurado a $37^{\circ} \mathrm{C}$ por 1 hora seguida de aquecimento a $95^{\circ} \mathrm{C}$ por 5 minutos e posterior espera a $4{ }^{\circ} \mathrm{C}$, após esse período o cDNA estava pronto para ser usado em qPCR ou estocado a $-20^{\circ} \mathrm{C}$.

\subsubsection{Definição dos genes de interesse para o estudo}

Para análise da expressão gênica, foram escolhidos genes baseados em estudos de Genome wide association (GWAS) relacionados a Doença Celíaca. Os transcritos 
dos genes selecionados exercem funções celulares diversas, entre elas a adesão celular e resposta imune e inflamatória na DC. São eles: $I L-15$; IL-15RA; IL-1; IL-1RA; IL-6; IL8; iNOS; NFkB; TLR-2; TLR-4; Zonulina; Ocludina e, como controle endógeno, GAPDH (VAN HEEL, et al., 2007; HUNT, et al., 2008; DUBOIS, et al., 2010, TRINKA 2011; WANG 2013). A Tabela 4, contém especificado a identidade dos genes e as sequências do primers forward $(\mathrm{F})$ e reverse $(\mathrm{R})$ de cada gene.

Tabela 3 - Conjuntos dos genes escolhidos, identidade e sequência dos pares de primers usados por q-PCR

\begin{tabular}{|c|c|c|c|}
\hline Gene / Id & Identidade & Função & Primers \\
\hline Zonulina & XM_006725560.1 & $\begin{array}{l}\text { Permeabilidade } \\
\text { celular }\end{array}$ & $\begin{array}{l}\text { F:5'GAATGATGGTTGGTATGGTGCG3' } \\
\text { R:5'TCAGAAGTGTGTCTACTGTCCG3' }\end{array}$ \\
\hline Ocludina & XM_006726213.1 & $\begin{array}{l}\text { Permeabilidade } \\
\text { celular }\end{array}$ & $\begin{array}{l}\text { F:5'ATGAGACAGACTACACAACTGG3' } \\
\text { R: 5'TTGTATTCATCAGCAGCAGC 3' }\end{array}$ \\
\hline IL-6 & NM_000600 & $\begin{array}{l}\text { Citocina } \\
\text { inflamatória }\end{array}$ & $\begin{array}{l}\text { F: 5'ATTCGTTCTGAAGAGGTGAGTG 3'; } \\
\text { R: 5’CCTTCCCTGCCCCAGTA 3' }\end{array}$ \\
\hline IL-8 & NM_000584.3 & $\begin{array}{l}\text { Citocina } \\
\text { inflamatória }\end{array}$ & $\begin{array}{l}\text { F: 5’CATCTTCACTGATTCTTGGATACC 3’; } \\
\text { R: 5'TGTCTGGACCCCAAGGAA 3' }\end{array}$ \\
\hline IL-15 & NR_037840 & $\begin{array}{l}\text { Citocina } \\
\text { inflamatória }\end{array}$ & $\begin{array}{l}\text { F: 5’AGCCCTGCACTGAAACAG 3'; } \\
\text { R: 5'CCACATTTGAGAAGTATTTCCATCC 3' }\end{array}$ \\
\hline IL-15RA & NM_001243539 & $\begin{array}{l}\text { Citocina } \\
\text { inflamatória }\end{array}$ & $\begin{array}{l}\text { F: 5'TTCCAAGTCTTCATCTCTGCTG 3'; } \\
\text { R: 5'CTGGCATGCTACCTCAAGT 3' }\end{array}$ \\
\hline IL-1 & NM_000575 & $\begin{array}{l}\text { Citocina } \\
\text { inflamatória }\end{array}$ & $\begin{array}{l}\text { F: 5'AGTTCTTAGTGCCGTGAGTTT C 3'; } \\
\text { R: 5'GTGACTGCCCAAGATGAAGA 3' }\end{array}$ \\
\hline IL-1RA & NM_000877 & $\begin{array}{l}\text { Citocina } \\
\text { inflamatória }\end{array}$ & $\begin{array}{l}\text { F: 5'CACTGTTTTTCCAAGACCTCA 3'; } \\
\text { R: 5'TTCCTGCTATGATTTTCTCCA 3' }\end{array}$ \\
\hline TLR-2 & NM_003264 & $\begin{array}{l}\text { Citocina } \\
\text { inflamatória }\end{array}$ & $\begin{array}{l}\text { F: 5'ATGACCCCCAAGACCCA 3'; } \\
\text { R: 5'CCATTGCTCTTTCACTGCTTTC 3' }\end{array}$ \\
\hline TLR-4 & NM_003266 & $\begin{array}{l}\text { Receptor de } \\
\text { membrana }\end{array}$ & $\begin{array}{l}\text { F: 5'ACCCCATTAATTCCAGACACA 3' } \\
\text { R: 5'GAGTATACATTGCTGTTTCCTGTTG3' }\end{array}$ \\
\hline NFkB1 & XM_006714229.1 & Monômero de NFkB & $\begin{array}{l}\text { F: 5’AAACACTGTGAGGATGGGATCTG 3'; } \\
\text { R: 5'CGAAGCCGACCACCATGT 3' }\end{array}$ \\
\hline iNOS & NM_000625 & Estresse oxidativo & $\begin{array}{l}\text { F: 5'CCTACGAGGCGAAGAAGGACAG 3'; } \\
\text { R: 5'CAGTTTGAGAGAGGAGGCTCCG 3'; }\end{array}$ \\
\hline GAPDH & NM_002046 & Controle endógeno & $\begin{array}{l}\text { F: 5'TGTAGTTGAGGTCAATGAAGGG 3’; } \\
\text { R: 5’ACATCGCTCAGACACCATG 3' }\end{array}$ \\
\hline
\end{tabular}

Gene forward (F) e reverse (R)

4.2.3 Reação em Cadeia da Polimerase quantitativa em Tempo-Real (q-PCR)

Os ensaios de amplificação foram realizados em placas de 96 poços e reação utilizando SYBR Green Maxima SYBR Green/Rox q-PCR mastermix (Thermo scientific, USA) que contém molécula fluorescente que se intercala em à fita dupla de cDNA. A 
detecção da expressão gênica por q-PCR foi feita pelo sistema StepOne® Real-Time PCR System (Applied BioSystems - Life Technologies ${ }^{\mathrm{TM}}$, Carlsbad, USA) que detecta em cada ciclo de amplificação a fluorescência da molécula SYBR Green.

Para a reação de q-PCR foi utilizado $10 \mu \mathrm{L}$ de SYBR Master Mix (2x); $2 \mu \mathrm{L}$ de primer foward; $2 \mu \mathrm{L}$ de primer reverse; $2 \mu \mathrm{L}$ de cDNA (30 ng/reação) e quantidade suficiente de água ultrapura (Invitrogen, Life techologies) para completar $20 \mu \mathrm{L}$ de reação. A amplificação constituiu de estágio a $95{ }^{\circ} \mathrm{C}$ por 10 minutos para ativação da enzima, seguidos de 40 ciclos de aquecimento a $95{ }^{\circ} \mathrm{C}$ por $15 \mathrm{seg}, 60{ }^{\circ} \mathrm{C}$ por 1 min e 72 ${ }^{\circ} \mathrm{C}$ por 30 segundos. As reações foram realizadas em triplicata para cada amostra e o gene $G A P D H$ foi usado como controle em todos os ensaios. Os valores estabelecidos do Base line e threshold foram determinados a partir dos valores fixados nos ensaios de eficiências para cada gene. Uma vez corrido o experimento, o aparelho irá produzir um valor de Ct para cada replicata técnica (são três replicatas por amostra), dessa forma é preciso calcular a média e o desvio padrão (Sd -Standand Deviation) dos Cts, então:

$\Delta C t=($ média CtTratamento - média CtTratamento gee endógeno $) \times$ tempo

$$
S d=\sqrt{S d A^{2}{ }^{2}+S d \text { Endógeno }^{2}}
$$

A normalização da quantificação relativa se deu pelo método $2^{-(\Delta \Delta \mathrm{C} t \pm \mathrm{Sd})}$, de Livak e colaboradores, 2001, onde:

$$
\Delta \Delta C t=(\Delta C t \text { Tratamento }-\Delta C t N T \text { Alvo }) \times \text { tempo }
$$

Para calcular a quantificação relativa dos genes pelo método $2^{-\Delta \Delta \mathrm{Ct}}$, foi utilizado DataAssist ${ }^{\mathrm{TM}}$ v3.01.

\subsubsection{Dosagem de Óxido Nítrico}

O Óxido Nítrico (NO) decompõe-se em nitritos $\left(\mathrm{NO}_{2}^{-}\right)$e nitratos $\left(\mathrm{NO}_{3}^{-}\right)$no meio de cultura e a produção de $\mathrm{NO}_{2}^{-}$pelas células pode ser dosada por ensaio colorimétrico baseado na reação de Griess ${ }^{\circledR}$. Para esse teste foram preparadas duas 
soluções: N-1-naphthyl etilenodiamina hidrocloreto (NEED) 0,2 \% em água e Sulfanilamida $2 \%$ em $\mathrm{H}_{3} \mathrm{PO}_{4} 5 \%$, que quando misturadas em proporções v/v para serem utilizadas no ensaio formam o reagente de Griess ${ }^{\circledR}$ (DE STEFANO et al., 2007). Para a dosagem do NO foi preparada curva de calibração com uma diluição seriada de Nitrito de Sódio nas seguintes concentrações: $100 \mu \mathrm{M}, 50 \mu \mathrm{M}, 25 \mu \mathrm{M}, 12,5 \mu \mathrm{M}, 6,25$ $\mu \mathrm{M}, 3,13 \mu \mathrm{M}$ e 1,56 $\mu \mathrm{M}$. Primeiramente $100 \mu \mathrm{L}$ de cada solução da curva de nitrito de sódio foi pipetada em triplicada em placa de 96 poços seguidas da pipetagem, também em triplicata, de $100 \mu \mathrm{L}$ dos sobrenadantes de cada grupo do experimento. Para o controle negativo, foram separados poços contendo apenas meio DMEM com $5 \%$ de SFB, sem amostra. Para a dosagem do NO, foram adicionados a cada poço $100 \mu \mathrm{L}$ do reagente de Griess ${ }^{\circledR}$. A leitura foi realizada em espectrofotômetro empregando filtro de $450 \mathrm{~nm}$ e os resultados foram expressos em $\mu \mathrm{mol} / \mathrm{L}$ de $\mathrm{NO}_{2}{ }^{-}$comparando a densidade óptica (DO) obtida com a DO da curva padrão de $\mathrm{NO}_{2}{ }^{-}$construída através de regressão linear.

\subsubsection{Dosagem das Citocinas}

Uma vez coletado o sobrenadante de cada estímulo nos respectivos tempos de 6, 24 e 48 horas, os mesmos foram congelados a $-20{ }^{\circ} \mathrm{C}$. Para a dosagem das citocinas os sobrenadantes foram descongelados a $8{ }^{\circ} \mathrm{C}$ e mantidos a temperatura ambiente por 30 minutos antes de iniciar com cada um dos protocolos de dosagens das citocinas.

Os Kits utilizados foram obtidos da IBL International GMHB ${ }^{T M}$ (Hamburg, Alemanha) para fins de pesquisa. Os Kits testados foram: Interleukin-21 (IL-21 REF:BE53211); Interleukin-2 (IL-2 REF:BE53021), Interleukin-6 high sensitivity (IL-6 REF:BE58061), Interleukin-8 (IL-8 REF:BE53081) e TNF-alpha (TNFa REF:BE55001). Todas as dosagens foram feitas no sistema automatizado Best-2000®, da INOVA Diagnostics Inc. (San Diego, CA, Estados Unidos).

Como pode ser observado na figura 8 , a dosagem das citocinas, de um modo geral, compartilham do mesmo princípio Enzyme Linked Immuno Sorbent Assay (ELISA), seguindo as recomendações do fabricante, com algumas particularidades específicas para cada citocina como por exemplo, diferentes tempos de incubação. 

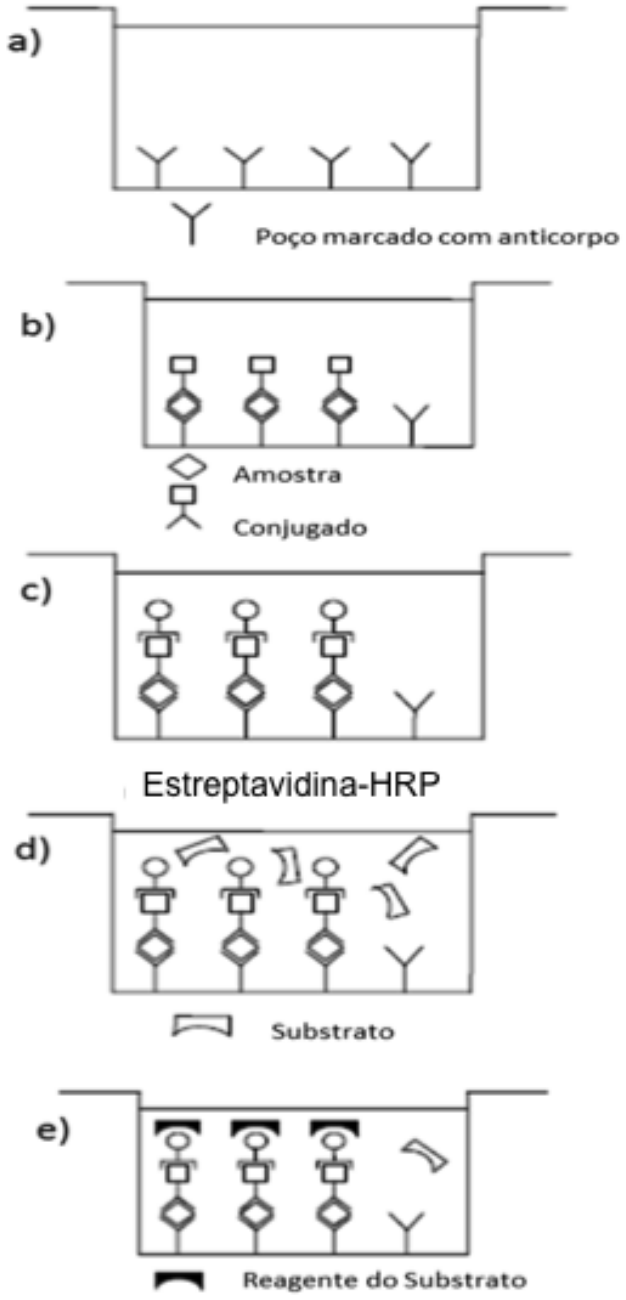

Figura 8 - Ilustração do ensaio de ELISA para as citocinas dosadas

A placa para detecção da citocina marcada com anticorpos policlonais anti-IgG e/ou anti-IgA aderidos à sua superfície interna inferior do poço foi bloqueada com uma formulação própria de proteínas, para evitar reações inespecíficas (Figura 8a). Inicialmente, o sobrenadante da amostra diluída 1:2 foi adicionada ao poço juntamente com o conjugado e incubado para promover forte ligação entre a citocina da amostra e o anticorpo marcado do poço e o conjugado que se liga ao anticorpo anti-citocina capturado pelo anticorpo do poço (Figura 8b).

Depois de incubado, o poço é lavado e é adicionado a enzima estreptavidina conjugada com peroxidase de rábano (estreptavidina-HRP) que se ligou ao primeiro complexo formado na primeira incubação e, novamente, a placa foi incubada e lavada (Figura 8c). Para a terceira incubação, foi adicionado substrato da enzima que reage com HRP (Figura 8d) e durante incubação o meio produzirá coloração proporcional a quantidade de citocina presente na amostra (Figura 8e). A reação foi finalizada 
medindo-se a absorbância a $450 \mathrm{~nm}$ e foi então determinada a concentração da citocina presente no meio em comparação a curva padrão de calibradores para cada citocina.

\subsubsection{Análise Estatística}

Para todos os testes estatísticos foi utilizado o software GraphPad Prism version 7.00 para Windows ( La Jolla, Califórnia, Estados Unidos).

O teste ANOVA de uma via foi aplicado para visualizar a variação da expressão gênica nas células desafiadas para cada um dos grupos nos três tempos abordados. O teste ANOVA de duas vias com pós-teste de Bonferroni foi utilizado em cada grupo para determinar se o tempo de interação com peptídeo influenciava ou não na expressão do fold-change ou dos níveis de citocinas quando comparada ao grupo Não Tratado (NT). Para visualizar a diferença para cada interação avaliada, foram construídas figuras em função do tempo com a média e desvio padrão para cada valor observado. 


\section{RESULTADOS}

\subsection{Resultados da Fase Analítica I}

\subsubsection{Seleção da Concentração Celular}

Neste estudo o primeiro experimento realizado foi a padronização da quantidade de células a serem utilizadas para obter o melhor desempenho dos ensaios que seriam realizados posteriormente. Inicialmente foram selecionadas duas concentrações celulares para avaliar o desempenho das células Caco-2. As quantidades definidas inicialmente foram: $5 \times 10^{5}$ e $5 \times 10^{6}$ por poço de placa de cultura de 6 poços.

Para o primeiro experimento cada uma das quantidades de células Caco-2 foram transferidas para poços de placa de cultura de 6 poços. Após atingirem confluência de aproximadamente $80 \%$ foram expostas aos estímulos LPS $1 \mu \mathrm{g} / \mathrm{mL}$ e gliadina 80 $\mu \mathrm{g} / \mathrm{mL}$ por 6 horas, 24 horas e 48 horas. Após receberem estes estímulos foi realizada a dosagem de óxido nítrico.

Os resultados apresentados na figura 9 demonstraram que as células na concentração de $5 \times 10^{5}$ responderam de maneira mais fidedigna aos estímulos. As células em concentração de $5 \times 10^{6}$ cresceram acima das taxas de confluência normais (verificado em microscopia), ao ponto de desprenderem-se dos poços, o que originaram concentrações elevadas de óxido nítrico, ou a impossibilidade de aferição da resposta nos tempos de $48 \mathrm{~h}$.

Os níveis de óxido nítrico produzidos pelas células na concentração 5 x $10^{5}$ após receberem estímulos de LPS $(1 \mu \mathrm{g} / \mathrm{mL})$ e gliadina $(80 \mu \mathrm{g} / \mathrm{mL})$, revelaram que a gliadina apresenta comportamento inflamatório semelhante ao produzido pelo LPS durante a cinética de tempo. 


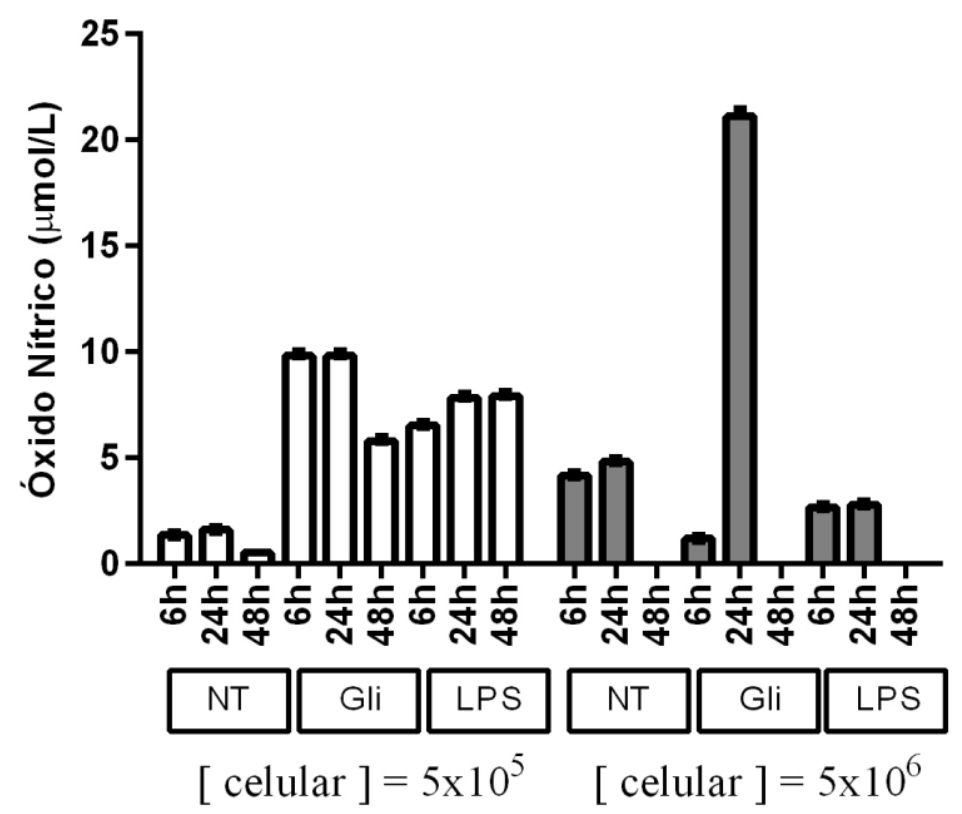

Figura 9 - Padronização da quantidade de células Caco-2

Dosagem de óxido nítrico em sobrenadante de cultura de células Caco-2 nas concentrações celulares de $5 \times 10^{5}$ e $5 \times 10^{6}$ nos tempos de 6 h, 24 h e 48 h, após estímulo com LPS e gliadina

\subsubsection{Ensaio para a Seleção da Concentração de LPS e gliadina}

Após estabelecida a quantidade de 5 a $10^{5}$ células Caco- 2 por poço a ser utilizada, foi preciso certificar que a concentração de LPS não influenciaria na produção de óxido nítrico pelas células e, que a reação não seria dose-dependente. Para esta finalidade, foram testadas concentrações de $1 \mu \mathrm{g} / \mathrm{mL}, 2 \mu \mathrm{g} / \mathrm{mL}$ e $3 \mu \mathrm{g} / \mathrm{mL}$ por $\mathrm{mL}$ de meio de cultura.

Na figura 10 observamos que o LPS na concentração de $1 \mu \mathrm{g} / \mathrm{mL}$ de meio foi mais eficiente em causar aumento relevante na dosagem de óxido nítrico nos tempos avaliados sendo, desta forma, a concentração escolhida para os experimentos posteriores. Entretanto, quando empregamos o dobro ou o triplo da concentração de LPS, observamos uma redução progressiva nos níveis de óxido nítrico produzido ao longo da cinética de tempo do estudo, o que demonstra que o estímulo não é dose dependente na indução de inflamação ou do aumento de óxido nítrico. 


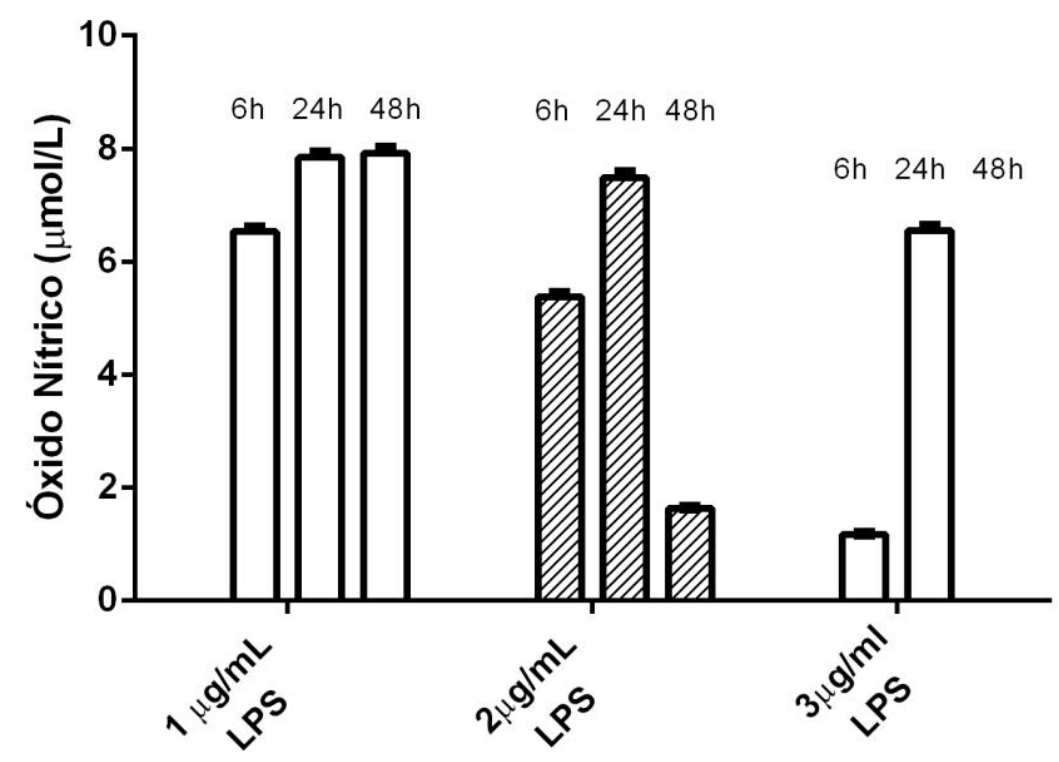

Figura 10 - Teste para estabelecer a concentração de LPS

Dosagem de Óxido Nítrico (NO) em células Caco-2 na concentração 5 x $10^{5}$ estimuladas com 1 $\mu \mathrm{g} / \mathrm{mL}, 2 \mu \mathrm{g} / \mathrm{mL}$ e $3 \mu \mathrm{g} / \mathrm{mL}$ de LPS nos tempos de 6,24 e 48 horas

O mesmo ensaio foi realizado para avaliar qual seria a melhor concentração de gliadina a ser utilizada. Inicialmente foram escolhidas as concentrações de $80 \mu \mathrm{g} / \mathrm{mL}$, $120 \mu \mathrm{g} / \mathrm{mL}$ e $160 \mu \mathrm{g} / \mathrm{mL}$ de gliadina. O ensaio demonstrou que a gliadina em concentração de $80 \mu \mathrm{g} / \mathrm{mL}$ foi a mais efetiva na produção de óxido nítrico nos tempos avaliados, sendo esta a concentração utilizada para os experimentos posteriores (Figura $11)$.

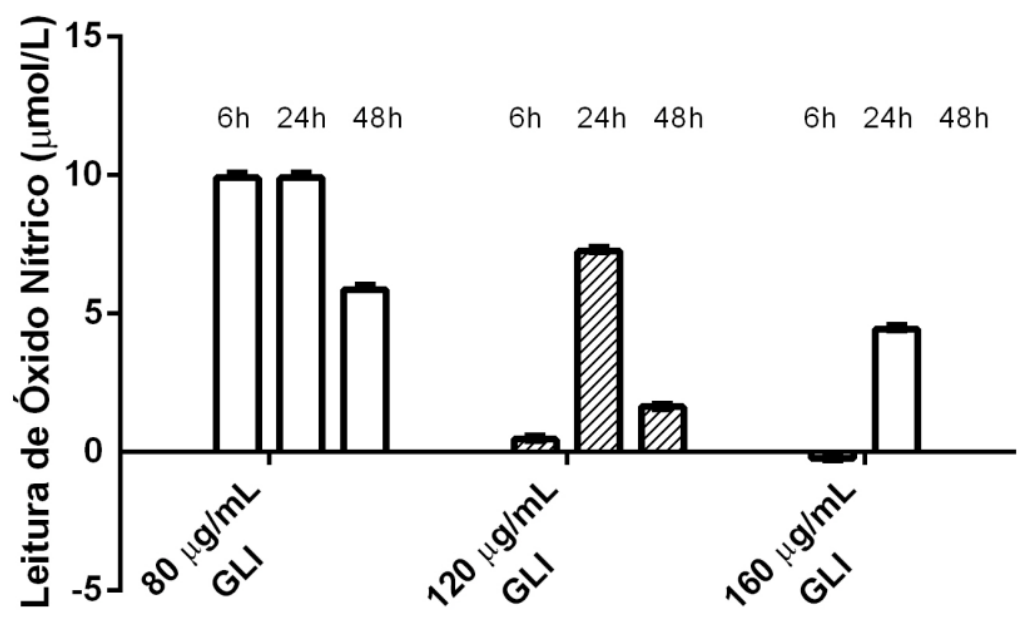

Figura 11 - teste para estabelecer a concentração de gliadina Dosagem de NO em células Caco-2 na concentração $5 \times 10^{5}$ estimuladas com $80 \mu \mathrm{g} / \mathrm{mL}, 120$ $\mu \mathrm{g} / \mathrm{mL}$ e $160 \mu \mathrm{g} / \mathrm{mL}$ de gliadina (GLI) nos tempos de 6, 24 e 48 horas 


\subsubsection{Ensaio de Viabilidade Celular}

Com o objetivo de avaliar a existência de interação química entre os reagentes utilizados neste estudo e o reagente WST-8, foi realizado ensaio sem células apenas na presença do reagente WST-8 com meio DMEM puro (branco), com meio DMEM com gliadina e com meio DMEM com LPS, nas concentrações previamente estabelecidas dos estímulos.

$\mathrm{Na}$ figura 12 observamos que os meios expostos aos reagentes apresentaram densidade óptica $\left(\mathrm{DO}_{450}\right)$ similar a observada no valor do branco. Por esta razão, foi possível inferir que não houve interação química relevante entre os reagentes ao ponto de se gerar uma resposta inespecífica.

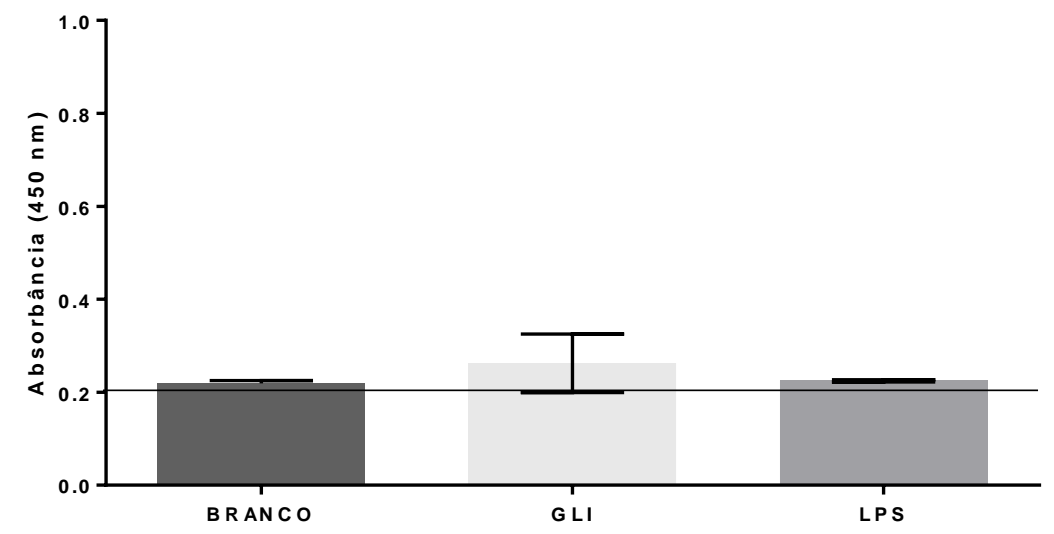

Figura 12 - Interação química entre reagentes

Teste de interação química entre os reagentes com WST-8 por 48 horas. Branco $=$ WST $-8+$ DMEM. GLI = WST-8 + gliadina. LPS = WST -8 + LPS

Após o ensaio de interação química entre os estímulos em meio DMEM e o reagente WST-8, avaliamos se houve interação dos estímulos nas concentrações empregadas no estudo sobre a viabilidade das células Caco-2. Na figura 13 a viabilidade celular na presença dos estímulos não foi afetada, sendo próxima a $100 \%$ para todos os estímulos empregados e não provocando toxicidade às células. 


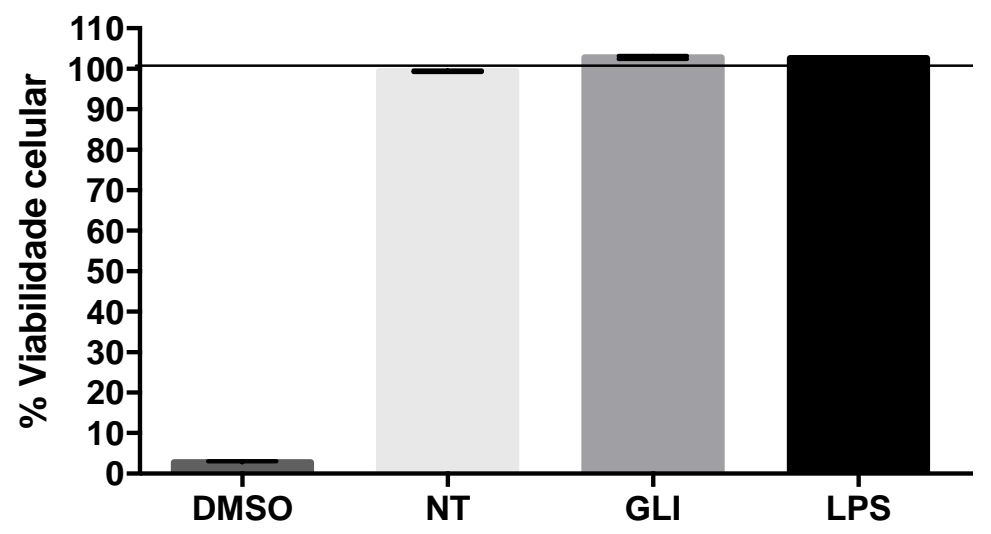

Figura 13 - Viabilidade celular

Teste de viabilidade celular pelo método WST-8 após interação entre células Caco-2 na concentração $5 \times 10^{5}$ por $48 \mathrm{~h}$ na presença de LPS $(1 \mu \mathrm{g} / \mathrm{mL})$ e gliadina $(80 \mu \mathrm{g} / \mathrm{mL})$

\subsubsection{Otimização do ensaio de q-PCR}

Para padronização das concentrações dos primers e forward, nove diferentes combinações de concentrações foram testadas. Foram verificadas apenas uma temperatura de melting $(\mathrm{Tm})$ para cada conjunto de primers, e não foi detectada presença de dímeros de primers. Dessa forma, a reação foi considerada específica para cada conjunto de primers.

Os ensaios de otimização da reação de qPCR geraram valores fixos de concentração de primers, quantidade de cDNA e valores determinados de Cycle treshold $(\mathrm{Ct})$ e Temperature melting $(\mathrm{Tm})$ correspondentes aos fixados nas eficiências que atingiram valores entre $90 \%$ e $110 \%$, cujas curvas foram calculadas a partir de Slope e $\mathrm{R}^{2}$. A partir desses resultados, pode-se seguir com as reações de qPCR por SYBR Green agora padronizadas. 
Tabela 4 - Otimização dos primers empregados na reação de q-PCR

\begin{tabular}{lcccccc}
\hline Gene & $\mathbf{n M}$ & $\boldsymbol{C t}$ & $\mathbf{T m}\left({ }^{\circ} \mathbf{C}\right)$ & Slope & $\mathbf{R 2}$ & Eficiência (\%) \\
\hline Zonulina & $300 / 300$ & 4,22 & 80,32 & $-3,35$ & 0,99 & 98 \\
\hline Ocludina & $300 / 300$ & 2,51 & 86,74 & $-3,38$ & 0,99 & 97 \\
\hline$I L-6$ & $600 / 600$ & 4,42 & 80,05 & $-3,25$ & 0,99 & 103 \\
\hline$I L-8$ & $300 / 300$ & 1,70 & 76,00 & $-3,29$ & 0,99 & 99 \\
\hline$I L-15$ & $300 / 300$ & 3,91 & 76,48 & $-3,18$ & 0,99 & 106 \\
\hline$I L-15 R A$ & $300 / 300$ & 2,03 & 83,33 & $-3,53$ & 0,99 & 91 \\
\hline$I L-1$ & $300 / 300$ & 1,90 & 79,79 & $-3,34$ & 0,97 & 98 \\
\hline$I L-1 R A$ & $300 / 300$ & 1,39 & 92,71 & $-3,52$ & 0,99 & 92 \\
\hline$T L R-2$ & $600 / 600$ & 4,11 & 78,71 & $-3,28$ & 0,99 & 101 \\
\hline TLR-4 & $600 / 600$ & 1,77 & 76,02 & $-3,56$ & 0,98 & 90 \\
\hline NFkB & $300 / 300$ & 2,48 & 78,72 & $-3,35$ & 0,99 & 98 \\
\hline GAPDH & $300 / 300$ & 2,88 & 84,53 & $-3,40$ & 0,99 & 96 \\
\hline PaP & $300 / 300$ & 2,5 & 81,00 & $-3,35$ & 0,99 & 98 \\
\hline
\end{tabular}

Para que o amplicon dobre de quantidade a cada ciclo, a eficiência da reação precisa estar entre $90 \%$ e $110 \%$, os valores de slope entre -3,1 e -3,6 e os valores de $\mathrm{R}^{2}$ devem estar o mais próximo possível de 1

\subsection{Resultados da Fase Analítica II}

\subsubsection{Análise do fold-change $\left(\log ^{2}\right)$ obtido por q-PCR}

No presente estudo, para todos os testes estatísticos utilizados, os valores lineares expressos de fold-change gerados pelo programa DataAssist ${ }^{\mathrm{TM}}$ (Life Technologies Corporation, Estados Unidos) foram convertidos em valores logarítmicos de base $2\left(\log ^{2}\right)$, o que significa que no eixo das ordenadas, os valores positivos representam os genes superexpressos, onde o valor de 1 fold-change em $\log ^{2}$ corresponde a 2 fold-change em valores lineares, que representam o quanto mais expressos este gene está em relação ao grupo não tratado, o valor de 2 fold-change em $\log ^{2}$ corresponde a 4 fold-change em valores lineares mais expressos e assim sucessivamente. O teste estatístico ANOVA de duas vias seguido de pós-teste Bonferoni foi aplicado nos valores em $\log ^{2}$ do fold-change.

Após a interação das células Caco-2 e realizado o ensaio de q-PCR para todos os genes do estudo foi determinado o Cycle treshould $(\mathrm{Ct})$ de cada gene individualmente, que foram inicialmente avaliados quanto à presença de amplificação antes de serem normalizados em relação ao grupo NT. Para a realização dessa análise, a média dos valores de Ct obtidos no ensaio de q-PCR para cada gene, sem excluir outliers foram 
plotados em um gráfico do tipo box-plot (Figura 14). De maneira geral, os resultados demonstram que houve amplificação para todos os genes estudados e que os Cts obtidos puderam ser normalizados após esta análise.

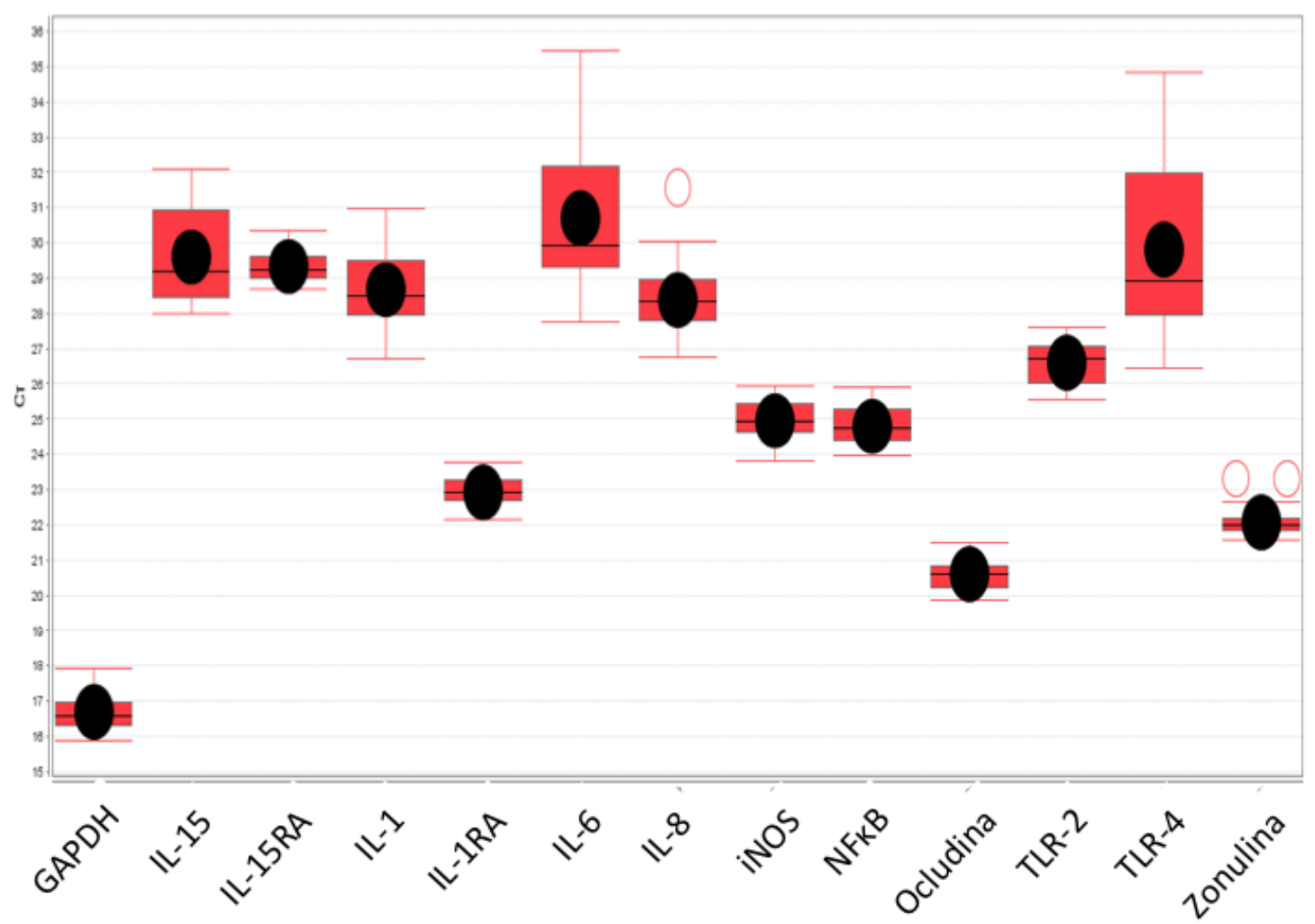

Figura 14 - Variação dos valores de $\mathrm{Ct}$ dos genes antes de normalizados Cada elemento individualmente representa a média de $50 \%$ dos valores de Ct. A linha horizontal e o ponto preto contém a mediana e a média dos valores de $\mathrm{Ct}$, respectivamente. As extremidades das linhas verticais (vermelhas) indicam os valores de $\mathrm{Ct}$ mínimos e máximos obtidos em todas as reações. Os pontos fora das linhas verticais são considerados outliers

Para visualizar a distribuição dos valores de fold-change $\left(\log ^{2}\right)$ para todas as interações nos tempos de 6, 24 e 48 horas, depois de normalizados com o grupo NT, o teste ANOVA de uma via foi aplicado para determinar se a variação de fold-change ( $\log 2)$ obtido para cada estímulo era diferentemente expresso ao longo do tempo quando comparado a média do grupo não tratado.

De todas as interações entre gliadina ou seus peptídeos e LPS com as células Caco-2, foram consideradas diferentemente expressas somente aquelas que apresentaram uma diferença maior que 1 fold-change $\left(\log ^{2}\right)$ para mais ou para menos, ou seja, duas vezes mais expressos ou menos expressos, e valores ajustados de $p<0,05$ em relação ao grupo não tratado. Das 288 interações (8 grupos x 3 tempos x 12 genes) 163 foram então consideradas diferentemente expressas quando comparadas com do 
grupo não tratado. Dessas, 150 foram consideradas superexpressas (valores positivos) e 13 subexpressas (valores negativos) (tabela 5).

De forma muito clara, é possível observar que a resposta às interações propostas por este estudo foram tempo dependente. Ao final das $48 \mathrm{~h}$ de estímulo observamos que o número de interações significativas superexpressas são maiores que as observadas no tempo inicial, depois de normalizadas com o grupo não tratado.

Tabela 5- Distribuição dos fold-change $\left(\log ^{2}\right)$ dos genes superexpressos e subexpressos ao longo do tempo

\begin{tabular}{lllll}
\hline & 6 horas & 24 horas & 48 horas & Total \\
\hline Superexpressos & 22 & 60 & 68 & 150 \\
Subexpressos & 10 & 2 & 1 & 13 \\
\hline
\end{tabular}

Para analisar a expressão gênica para cada peptídeo de gliadina testado, foi gerado figuras mostrando o valor do fold-change $\left(\log ^{2}\right)$ (expresso como média e desvio padrão) ao longo dos tempos de 6, 24 e 48 horas de exposição ao peptídeo. Os resultados descritivos dos testes estatísticos podem ser observados a seguir.

\subsubsection{Análise da expressão gênica após estímulo com gliadina e LPS}

Uma vez que o LPS é considerado um bom controle positivo para gerar uma resposta inflamatória não específica, foi comparado o fold-change $\left(\log ^{2}\right)$ gerado pelo LPS e pela gliadina a fim de observar se a resposta inflamatória da gliadina poderia ser tão representativa quanto do LPS. A figura 15 ilustra a diferença de fold-change $\left(\log ^{2}\right)$ dos transcritos gênicos de $I L-15, I L-15 R A, I L-1, I L-1 R A, I L-6$ e $I L-8$ observada após estímulo com LPS e gliadina nos tempos de 6, 24 e 48 horas quando comparado ao grupo não tratado (NT).

$\mathrm{Na}$ figura 15a, nos valores de fold-change $\left(\log ^{2}\right)$ dos transcritos de $I L-15$ observa-se que os estímulos de LPS e gliadina apresentaram, respectivamente, resultados em fold-change $\log ^{2}$ de 1,96 e 1,97, que correspondem a valores lineares numéricos de expressão de transcritos gênicos de 2,93 e 2,94, e representam o número de vezes mais expressos que o NT com 24 horas de estímulo, e de 3,62 e 3,15 em $\log ^{2}$ que correspondem a valores lineares de 11,35 e 7,90 de transcritos do gene, onde o gene 
está mais expresso com 48 h após estímulo quando comparado à expressão do mesmo gene no grupo NT.

Estes valores de fold-change $\left(\log ^{2}\right)$ foram estatisticamente significativos nos tempos de 24 horas $(p<0,0001)$ e 48 horas $(p<0,0001)$ para LPS e nos tempos de 24 horas $(p<0,0001)$ e 48 horas $(p<0,0001)$ para gliadina, quando comparados ao NT. É possível então inferir que, tanto o LPS quanto a gliadina apresentaram aumento das diferenças de fold-change $\left(\log ^{2}\right)$ ao longo do tempo em relação ao NT.

O mesmo não pode ser observado nas diferenças de fold-change $\left(\log ^{2}\right)$ dos transcritos de $I L-15 R A$ (Figura 15b), onde nenhum dos transcritos do gene apresentou valores de fold-change $\left(\log ^{2}\right)$ maiores que 1 .

Para os transcritos de $I L-1$ na figura 15 c, foi observado que o número de transcritos após estímulo com LPS foram equivalentes a 1,83 (linear 2,56) e 1,77 (linear 2,40 ), enquanto que para gliadina os resultados obtidos foram 1,85 (linear 2,62) e 1,25 (linear 1,37) nos tempos de 24 horas e 48 horas respectivamente, que representam quão mais expresso os transcritos dos genes estão após estímulo com LPS em relação ao não tratado. Houve diferença significativa para LPS e gliadina nos tempos de 24 e 48 horas, apresentando valores de $p<0,0001 \mathrm{em}$ ambos. Quanto à expressão de transcritos do gene $I L-1 R A$ (Figura 15d) não houve modulação de fold-change $\left(\log ^{2}\right)$ superior a 1 .

Comparando os dados observados nos fold-change $\left(\log ^{2}\right)$ para $I L-15$ e $I L$ 15RA, IL-1 e IL-1RA, observamos comportamento semelhante. Os transcritos gênicos de $I L-15$ e $I L-1$ aumentam de expressão em comparação ao não tratado, mas o mesmo não ocorre com os seus receptores $I L-15 R A$ e $I L-1 R A$, que não modificaram sua expressão gênica em relação ao NT.

As diferenças de fold-change $\left(\log ^{2}\right)$ para os transcritos de $I L-6$, na figura $15 \mathrm{e}$, para os tempos de 24 e 48h foram 3,70 e 4,09 (linear 12,04 e 16,12) para os estímulos com LPS e 3,98 e 3,70 (linear 14,86 e 12,05) para os estímulos com gliadina, respectivamente, os resultados refletem maior expressão de transcritos do gene em relação aos NT. As diferenças foram estatisticamente significativas $(p<0,0001)$ para LPS e gliadina também nestes tempos. De maneira geral podemos afirmar que os transcritos de $I L-6$ se modularam semelhantemente entre os estímulos de LPS e de gliadina.

Para os transcritos de $I L-8$ (Figura 15f) houve aumento significativo de expressão do fold-change $\left(\log ^{2}\right)$ em relação ao NT para os tempos de 6, 24 e 48 horas 
quando estimulados com LPS, sendo estes 1,4, 2,05 e 1,10 (linear 1,63, 3,16 e 1,15), respectivamente, com valores de $p<0,001$. Enquanto que para gliadina não houve modulação dos transcritos do gene.

Em uma análise preliminar, podemos sugerir que os estímulos de LPS e gliadina modularam a expressão dos transcritos de $I L-15, I L-1, \quad I L-6$ e $I L-8$, principalmente nos tempos de 24 e 48 horas. 

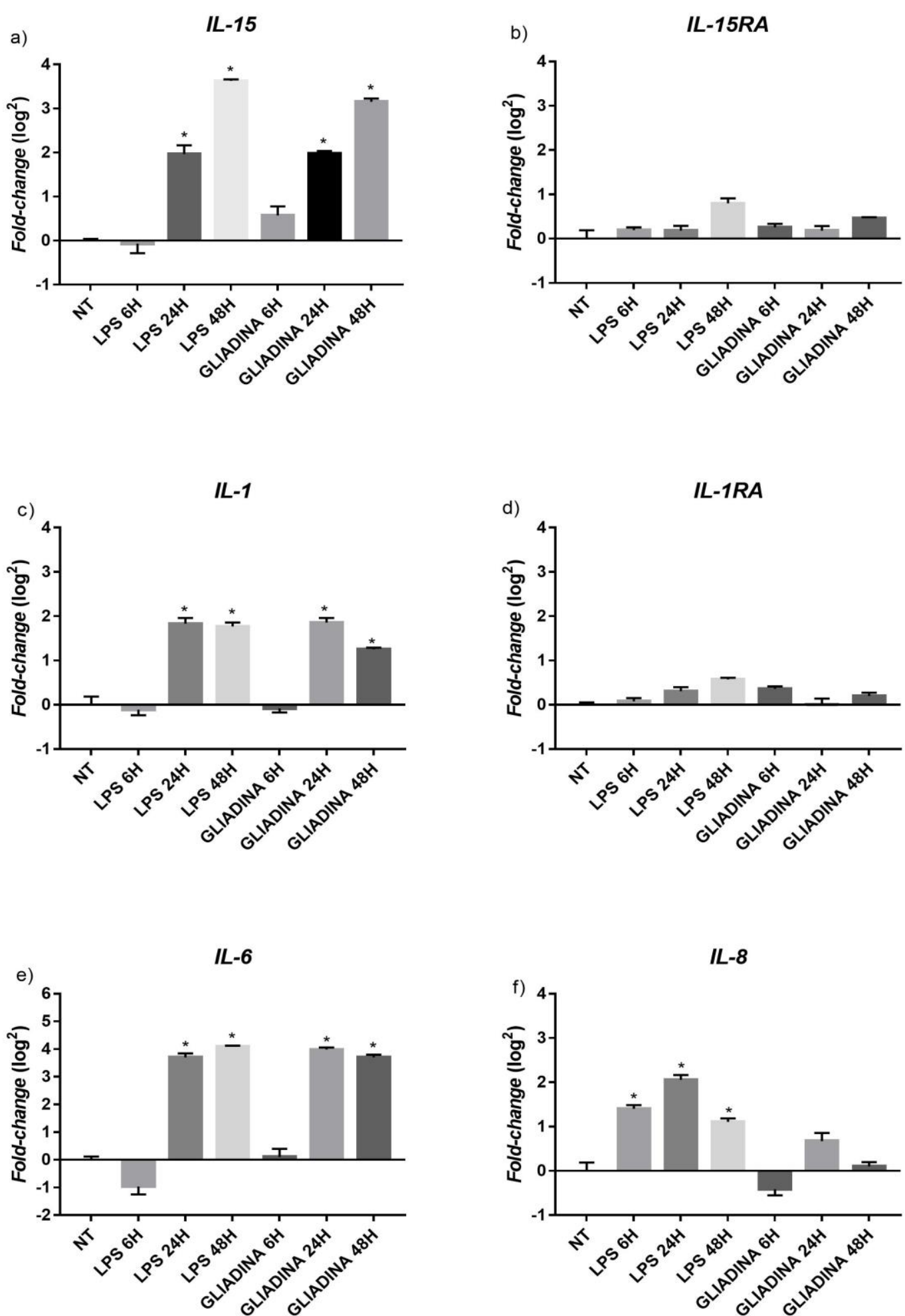

Figura 15 - Modulação da expressão de transcritos gênicos em células Caco-2 estimuladas com LPS e gliadina por 6 horas, 24 horas e 48 horas

Diferenças de fold-change $\left(\log ^{2}\right)$ para os transcritos de $I L-15$ (a), IL-15RA (b), IL-1 (c), IL-1RA (d), $I L-6$ (e) e $I L-8$ (f)

Os valores representam média e desvio padrão dos fold-change $\left(\log ^{2}\right)$. Análise estatística $* p<$ 0,000 
A figura 16 ilustra a diferença de fold-change $\left(\log ^{2}\right)$ dos transcritos gênicos de TLR-2, TLR-4, iNOS, NFkB, Ocludina e Zonulina obsevada após a interação com LPS e gliadina nos tempos de 6, 24 e 48 horas comparadas ao grupo não tratado (NT).

$\mathrm{Na}$ figura 16a, observamos que nos transcritos gênicos de TLR-2 apresentaram fold-change $\left(\log ^{2}\right)$ de 1,06 (linear 1,12) e $p<0,0001$, apenas na presença do LPS em 48 horas de estímulo.

As maiores diferenças de fold-change $\left(\log ^{2}\right)$ em relação ao NT apresentadas no presente estudo após estímulos com LPS e gliadina, foram observadas para os transcritos gênicos de TLR-4 (Figura 16b) com 24 e 48 horas de estímulo. Para LPS 24 e 48 horas, as diferenças de fold-change ( $\left.\log ^{2}\right)$ foram de 5,70 e 6,56 que representam um aumento de expressão em valores lineares de 51,22 e 93,52 em comparação com o grupo NT, com ambos apresentando valores de $p<0,0001$. O mesmo é observado para gliadina com 24 e 48 horas de estímulo, onde fold-change representaram um aumento de 5,83 e 5,79 $\left(\log ^{2}\right)$, que correspondem a valores lineares de 55,86 e 54,42 para os dois tempos, respectivamente, com valores de $p<0,0001$ comparado ao NT para ambos.

Para os transcritos de iNOS (Figura 16c), a diferenças de fold-change $\left(\log ^{2}\right)$ foi estatisticamente significativa para LPS no tempo de 48 horas $(p<0,0001)$ com valores logarítmicos observados 1,13, e valores lineares de 1,19 maiores que o NT. Para os estímulos LPS e gliadina, nos transcritos de $N F k B$, não houve modulação dos transcritos gênicos em fold-change $\left(\log ^{2}\right)$ superiores a 1 (Figura 16d).

As diferenças de fold-change $\left(\log ^{2}\right)$ para os transcritos de Ocludina (Figura 16e), quando comparadas com o NT, foram significativas para os tempos de 24 e 48 horas tanto para LPS quanto para gliadina, apresentando valores em $\log ^{2}$ de 1,31 e 1,06 respectivamente, que correspondem a valores lineares de 1,49 e 1,09. Valores de $p<$ 0,0001 foram encontrados para ambos os estímulos no tempo de 48h.

Para os transcritos de Zonulina, apenas no tempo de 48 horas após estímulo com LPS houve modulação do gene com valores logarítmicos de 1,03 que correspondem a valores numéricos lineares de 1,04 e representam quanto o gene foi mais expresso que o NT.

Em uma análise preliminar, podemos sugerir que o estímulo LPS no tempo de 48h modulou a expressão de forma semelhante para os genes TLR-2, iNOS, Ocludina e Zonulina, e que ambos os estímulos gliadina e LPS nos tempos de 24 e $48 \mathrm{~h}$ modularam fortemente a expressão de transcritos do gene TLR-4. 
TLR-2
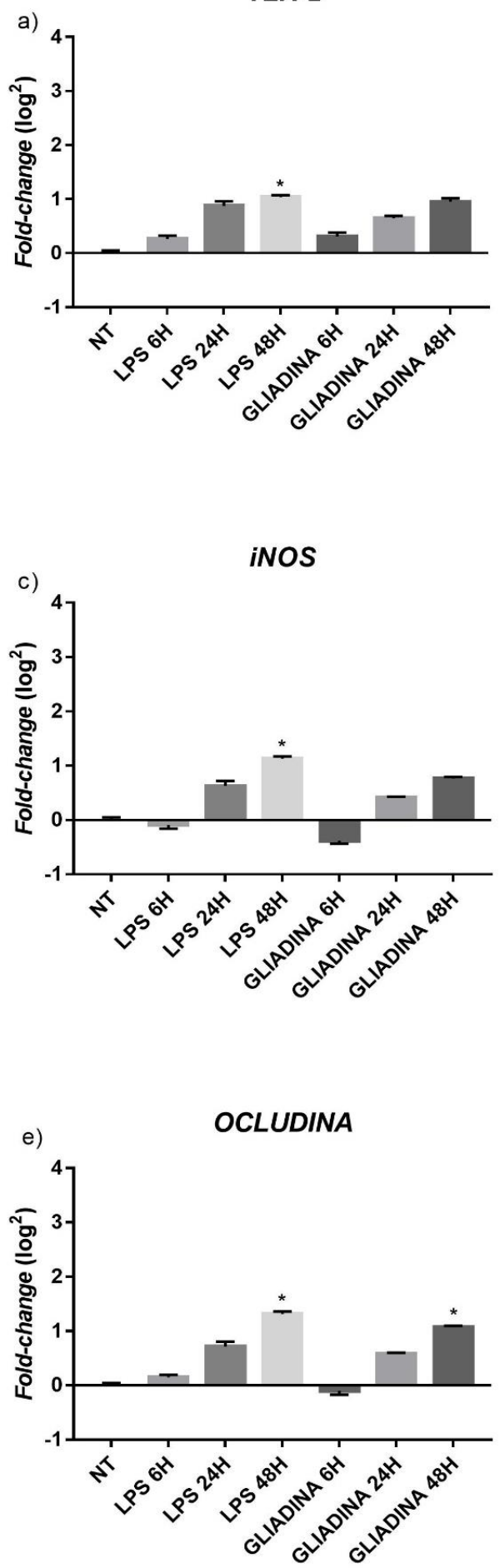
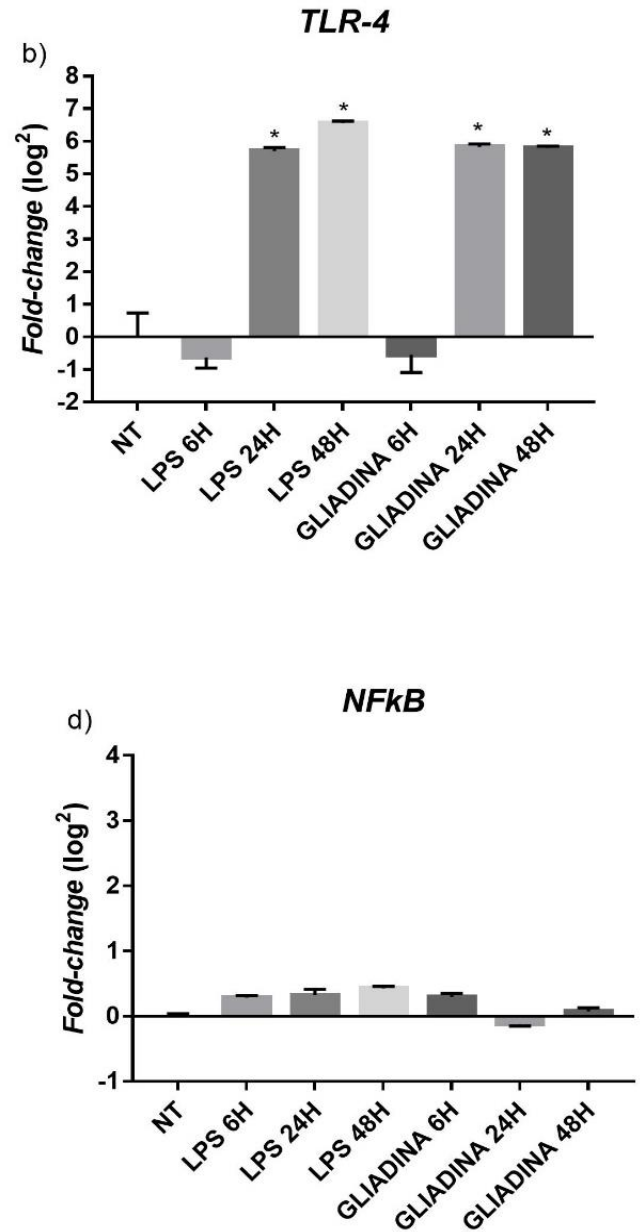

ZONULINA

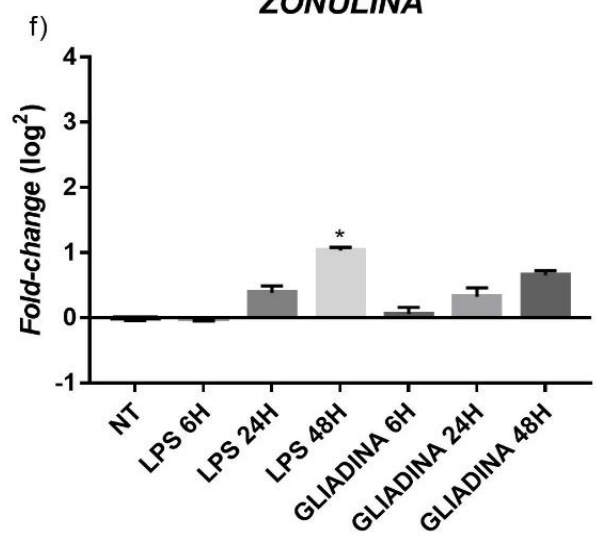

Figura 16 - Modulação da expressão de transcritos gênicos em células Caco-2 estimuladas com LPS e gliadina por 6 horas, 24 horas e 48 horas

Diferenças de fold-change ( $\log ^{2}$ ) para os transcritos de TLR-2 (a), TLR-4 (b), iNOS (c), NFkB (d), Ocludina (e) e Zonulina (f)

Os valores representam média e desvio padrão dos fold-change $\left(\log ^{2}\right)$. Análise estatística $* p<$ 0,0001 


\subsubsection{Análise da expressão gênica após estímulo com p56-88 (P1)}

Para fim de comparação, os valores de fold-change $\left(\log ^{2}\right)$ de cada peptídeo foram agrupados juntos aos valores obtidos da interação das células Caco-2 com gliadina, uma vez que a interação com gliadina se mostrou similar ao LPS.

$\mathrm{Na}$ figura 17a, estão demonstrados as diferenças de fold-change $\left(\log ^{2}\right)$ dos transcritos de demonstradaseração com p56-88 (P1). Para os tempos de 24 e 48 horas após estímulo com p56-88 (P1), as diferenças de fold-change $\left(\log ^{2}\right)$ foram de 2,16 para 24 horas (linear 3,48) e 3,62 (linear 11,38) para 48 horas em comparação com o NT, diferenças estatísticas de $p<0,0001$ foi encontrada para ambos os tempos. Quando o estímulo avaliado foi a gliadina, os valores de fold-change $\left(\log ^{2}\right)$ encontrados foram 1,97 para 24 horas com valores lineares de 2,94 e de 3,15 para 48 horas com valores lineares de 7,90 que em ambas os tempos representam o aumento do número de transcritos do gene em relação ao NT, novamente valores de $p<0,0001$ foram encontrados para ambos.

Observa-se que tanto o p56-88 (P1) quanto a gliadina apresentaram aumento de fold-change $\left(\log ^{2}\right)$ ao longo do tempo em relação ao NT, evidenciando a modulação nos transcritos de $I L-15$. Porém, quando observamos a expressão dos transcritos de seu receptor, IL-15RA, não verificamos diferenças de fold-change $\left(\log ^{2}\right)$ superiores a 1 (Figura 17b).

Para os transcritos gênicos de $I L-1$, na figura 17 c, foi observada modulação do gene após estímulo com p56-88 (P1) e gliadina nos tempos de 24 e 48 horas, apresentando valores de fold-change $\left(\log ^{2}\right)$ de 2,08 e 1,53 para p56-88 (P1) e 1,85 e 1,25 para gliadina, que correspondem a valores lineares de 3,24 e 1,91 para p56-88 (P1), e 2,62 e 1,37 para gliadina, respectivamente quando comparados ao NT. Em todas as modulações valores ajustados de $p<0,0001$ foram encontrados quando em comparação ao NT.

Para as células estimuladas com p56-88 (P1) e gliadina não houve modulação dos transcritos gênicos de $I L-1 R A$ (Figura 17d).

A diferença de fold-change $\left(\log ^{2}\right)$ observada para os transcritos de IL-6 (Figura 17e), foram valores de 3,58 e 3,21 (linear 11,0 e 8,39) após 24 e 48 horas de estímulo com p56-88 (P1), com valor de $p<0,0001$ para ambos os tempos quando comparados 
ao NT. Os valores de fold-change ( $\left.\log ^{2}\right)$ 3,98 e 3,70 (linear 14,86 e 12,05) foi observado para o estímulo com gliadina, novamente valores de $p<0,0001$ foram encontrados nos tempos de 24 e 48 horas em comparação com o NT.

Para os transcritos do gene $I L-8$ (Figura 17f) observa-se superexpressão após 24 horas de estímulo com p56-88 (P1) $(p<0,0001)$, com valor de fold-change $\left(\log ^{2}\right)$ 1,57 e valor linear 1,96 maior que o NT.

Novamente os estímulos gliadina e p56-88 (P1) modularam a expressão de transcritos dos genes $I L-15$, IL- 1 e $I L-6$ nos tempos de 24 e 48 horas. 

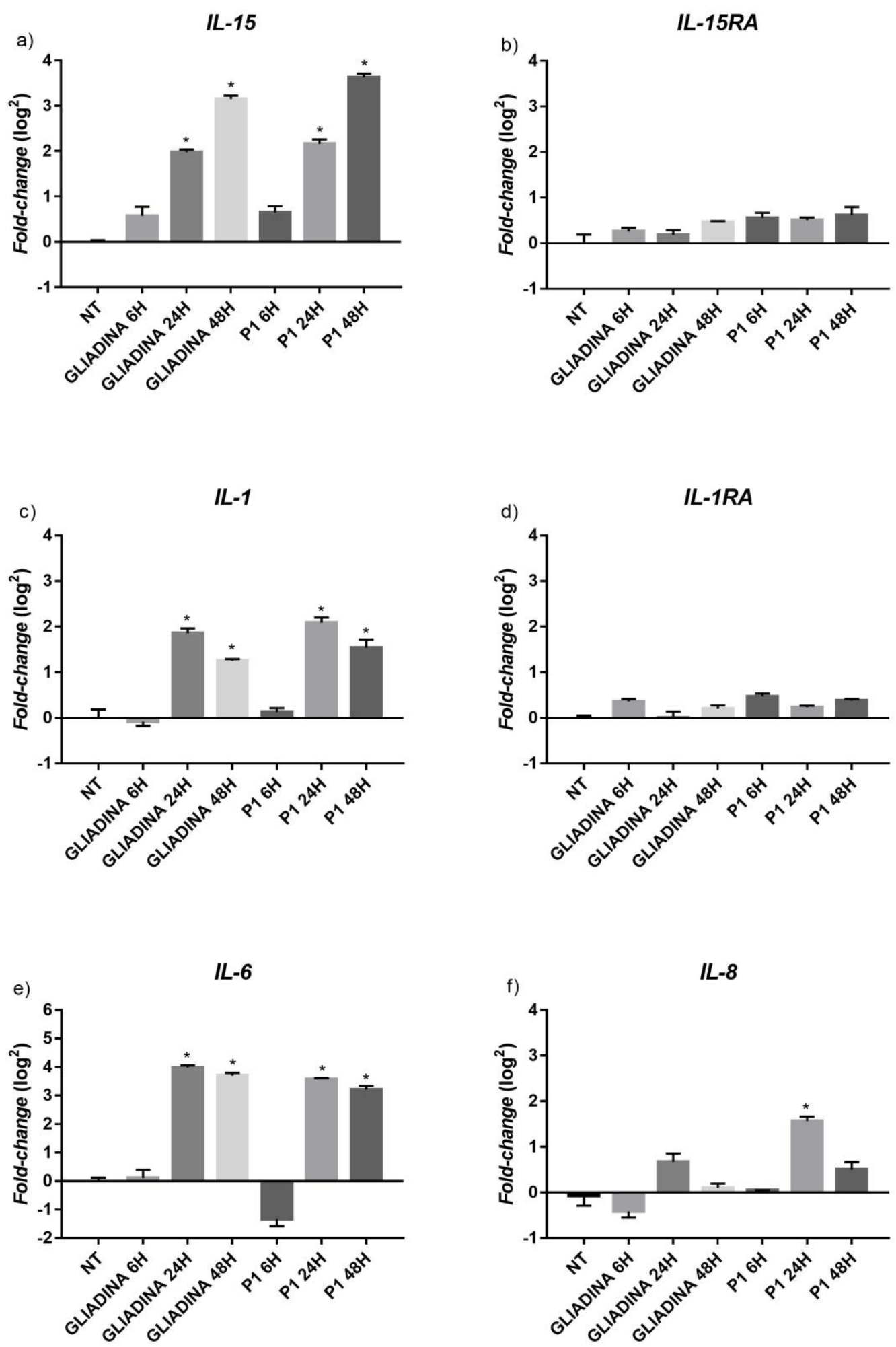

Figura 17 - Modulação da expressão de transcritos gênicos em células Caco-2 estimuladas com gliadina e p56-88 (P1) por 6 horas, 24 horas e 48 horas

Diferenças de fold-change ( $\left.\log ^{2}\right)$ para os transcritos de $I L-15$ (a), IL-15RA (b), IL- 1 (c), IL-1RA (d), $I L-6$ (e) e $I L-8$ (f)

Os valores representam média e desvio padrão dos fold-change $\left(\log ^{2}\right)$. Análise estatística $* p<$ 0,0001 
A figura 18 ilustra a diferença de fold-change $\left(\log ^{2}\right)$ dos transcritos gênicos de TLR-2, TLR-4, iNOS, NFkB, Ocludina e Zonulina obsevada após tempos de 6, 24 e 48 horas de interação com gliadina e p56-88 (P1) comparadas ao grupo não tratado (NT).

Os transcritos de TLR-2, iNOS, NFKB e Zonulina (Figura 18a, c, d f), após a interação com os estímulos gliadina e p56-88 (P1), não apresentaram modulação dos transcritos gênicos em fold-change $\left(\log ^{2}\right)$, não sendo observado diferenças iguais ou maiores que 1.

Para os transcritos de TLR-4 (Figura 18b) as diferenças de fold-change $\left(\log ^{2}\right)$ em relação ao NT foram de 5,13 (linear 34,11) no tempo de 24 horas ( $p<0,0001$ ), e 5,33 (linear 39,41) após 48 horas de interação $(p<0,0001)$. As diferenças de foldchange $\left(\log ^{2}\right)$ foram semelhantes para gliadina e p56-88 (P1) quando comparadas com o grupo NT.

Para os transcritos de Ocludina (Figura 18e) após 48 horas de interação com gliadina e p56-88 (P1) mostraram-se modulados apresentando fold-change $\left(\log ^{2}\right)$ com valores de 1,06 e 1,21 e valores lineares correspondentes de 1,09 e 1,32 (ambos com $p<$ $0,0001)$.

A gliadina e o peptídeo p56-88 (P1) modulou principalmente transcritos do gene $T L R-4$ com 24 horas (5,83 e 5,13 em $\log ^{2}$ e, 55,86 e 34,11 lineares) e 48 horas de interação ( $\log ^{2} 5,79$ e 5,33 e, lineares 54,42 e 39,41); e de forma pontual houve modulação gênica dos transcritos do gene Ocludina apenas no tempo de $48 \mathrm{~h}$, modulação também observada após estímulo com a gliadina para este mesmo gene. 

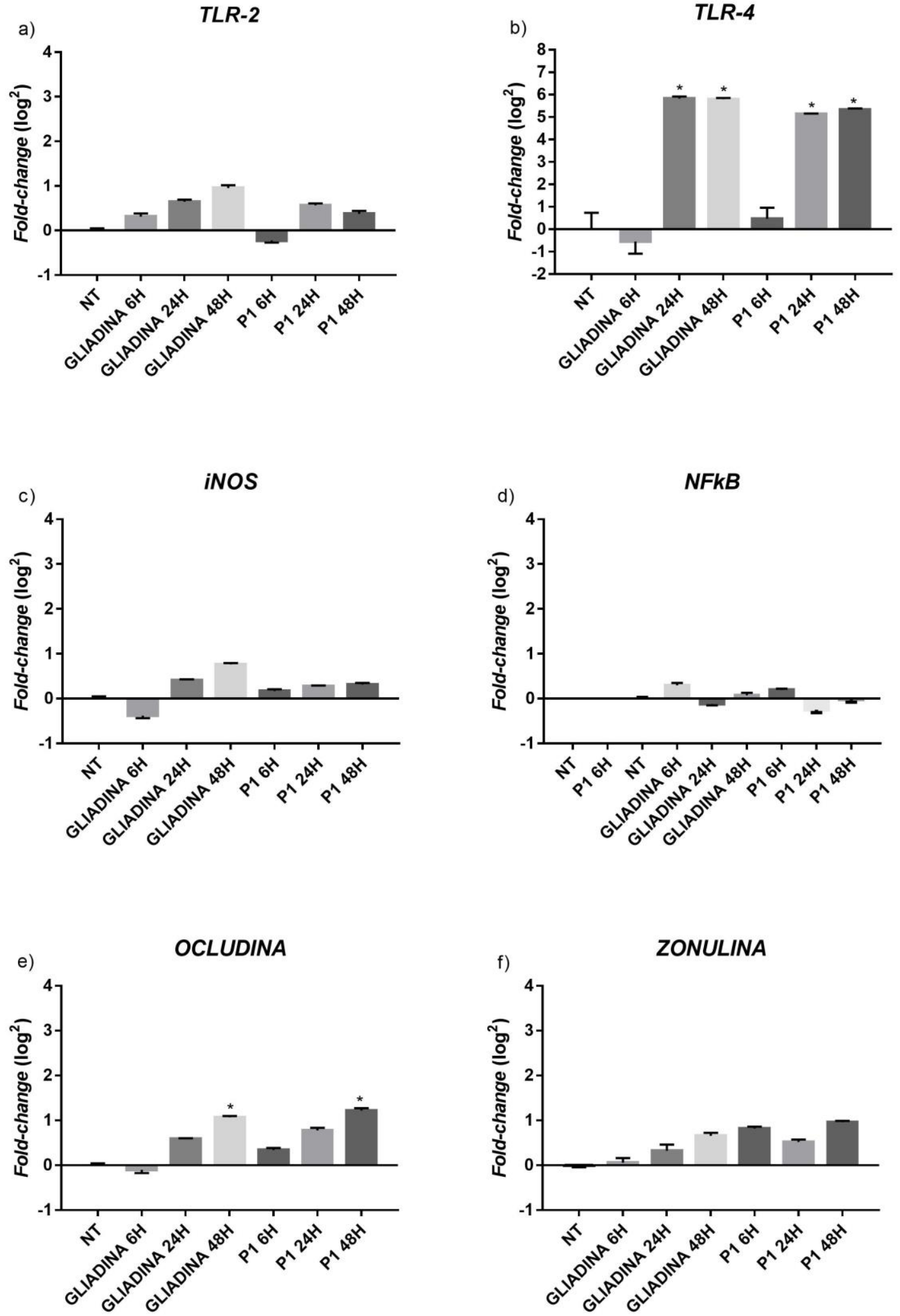

Figura 18 - Modulação da expressão de transcritos gênicos em células Caco-2 estimuladas com gliadina e p56-88 (P1) por 6 horas, 24 horas e 48 horas

Diferenças de fold-change ( $\left.\log ^{2}\right)$ para os transcritos de TLR-2 (a), TLR-4 (b), iNOS (c), NFkB (d), Ocludina (e) e Zonulina (f)

Os valores representam média e desvio padrão dos fold-change $\left(\log ^{2}\right)$. Análise estatística $* p<$ 0,0001 


\subsubsection{Análise da expressão gênica após estímulo com p57-68 (P2)}

As diferenças de fold-change $\left(\log ^{2}\right)$ dos transcritos de $I L-15, I L-15 R A, I L-1, I L$ IRA, IL-6 e $I L-8$, resultados da interação das células Caco-2 com gliadina e o peptideo de gliadina p57-68 (P2) estão representadas na figura 19.

Observa-se que para o gene $I L-15$ a diferença de fold-change $\left(\log ^{2}\right)$ na presença de gliadina foi de 1,97 e 3,15 com valores lineares de 2,94 e 7,90 para 24 e 48h, respectivamente. Após estímulo com p57-68 (P2) a diferença de fold-change $\left(\log ^{2}\right)$ foi de 2,12 (24 horas) e 3,30 (48 horas) com valores lineares correspondentes de 3,37 e 8,90 mais expresso que o não tratado. Em todos os tempos e estímulos, valores de $p<0,0001$ foram obtidos na comparação com o NT (Figura 19a).

Em relação aos níveis de expressão de transcritos do gene $I L-15 R A$ (Figura 19b), bem como IL-1RA (Figura 19d) não houve modulação destes genes com foldchange $\left(\log ^{2}\right)$ superior ou igual a 1 .

Para $I L-1$, a diferença de fold-change $\left(\log ^{2}\right)$ para a gliadina foi 1,85 e 1,25 para 24 e 48 horas respectivamente, com valores lineares de 2,62 e 1,37 mais expressos em comparação ao NT, com $p<0,0001$. Quando p57-68 (P2) foi o estímulo valores de foldchange $\left(\log ^{2}\right)$ foram 2,92 e de 1,77 com valores lineares de 6,61 e 2,41 nos tempos de 24 e 48 h (Figura 19c).

Para os transcritos de $I L-6$ as diferenças de fold-change $\left(\log ^{2}\right)$ para gliadina foram de 3,98 e 3,70 (valores lineares 14,86 e 12,05) quando comparadas com NT, enquanto para p57-68 (P2) foram de 2,12 e de 3,06 para os tempos de 24 e 48 h (linear de 3,36 e 7,40, respectivamente), quando comparados ao NT, com valores de $p<0,0001$ (Figura 19e) para ambos.

A diferença de fold-change $\left(\log ^{2}\right)$ para o transcrito de $I L-8$ foi de 1,97 que corresponde ao valor linear de 2,93 após estímulo com p57-68 (P2) no tempo de 24h, e representa quantas vezes o gene está mais expresso que o NT ( $p<0,0001)$ (Figura 19f). 

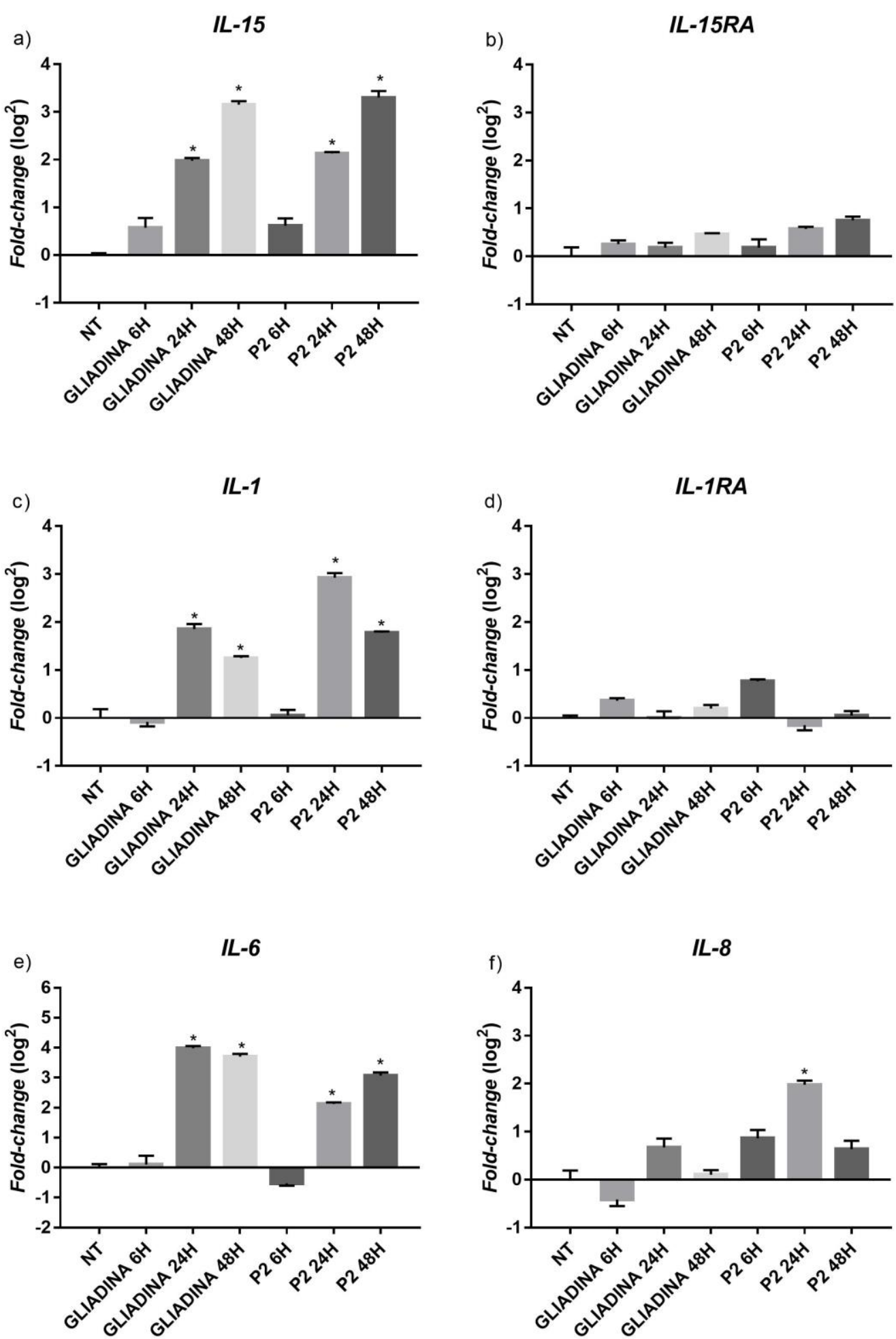

Figura 19 - Modulação da expressão de transcritos gênicos em células Caco-2 estimuladas com gliadina e p57-68 (P2) por 6 horas, 24 horas e 48 horas

Diferenças de fold-change ( $\left.\log ^{2}\right)$ para os transcritos de $I L-15$ (a), IL-15RA (b), IL- 1 (c), IL-IRA (d), $I L-6$ (e) e $I L-8$ (f)

Os valores representam média e desvio padrão dos fold-change $\left(\log ^{2}\right)$. Análise estatística $* p<$ 0,0001 
$\mathrm{Na}$ figura 20 estão representadas as diferenças de fold-change $\left(\log ^{2}\right)$ dos transcritos de TLR-2, TLR-4, iNOS, NFkB, Ocludina e Zonulina após a interação das células Caco-2 com gliadina e o p57-68 (P2), para os tempos de 6, 24 e 48 h de estímulo.

Não houve modulação dos genes TLR-2 (Figura 20a), iNOS (Figura 20c) , NFkB (Figura 20d), Zonulina (Figura 20e) e Ocludina (Figura 20f) para os transcritos gênicos da interação com p57-68 (P2).

Para TLR-4, as diferenças de fold-change $\left(\log ^{2}\right)$ na presença de gliadina foram de 5,83 e 5,79 com valores lineares de 55,86 e 54,42 para 24 e 48 horas de interação, respectivamente $(p<0,0001)$, e após estímulo com p57-68 (P2) o fold-change $\left(\log ^{2}\right)$ obtido foi de 3,64 e 5,10 que representam 11,43 e 33, 32 em valores lineares, demonstrando o aumento da expressão dos transcritos do gene em comparação com o NT $(p<0,0001)$ (Figura 20b). 

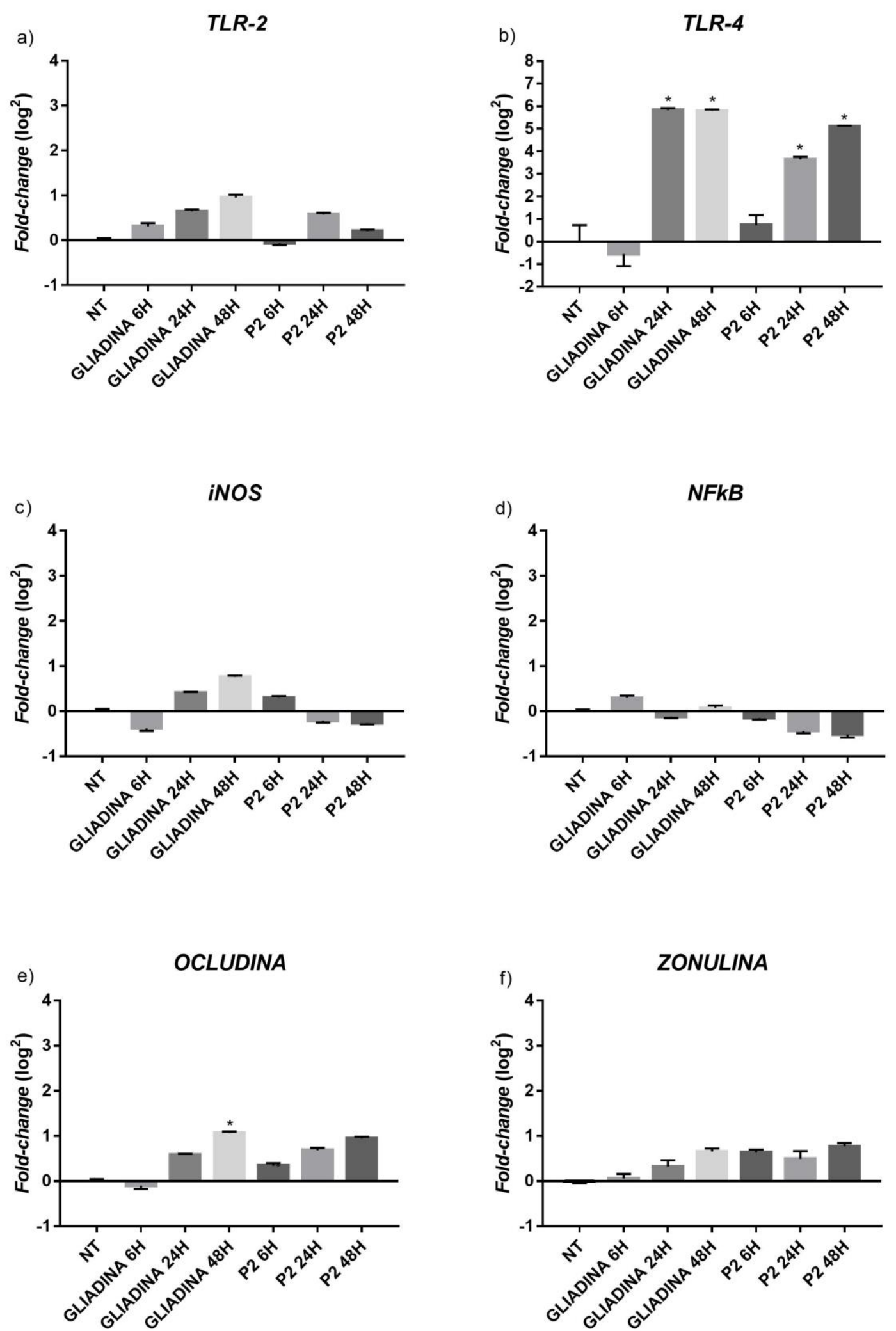

Figura 20 - Modulação da expressão de transcritos gênicos em células Caco-2 estimuladas com gliadina e p57-68 (P2) por 6 horas, 24 horas e 48 horas

Diferenças de fold-change $\left(\log ^{2}\right)$ para os transcritos de TLR-2 (a), TLR-4 (b), iNOS (c), NFkB (d), Ocludina (e) e Zonulina (f)

Os valores representam média e desvio padrão dos fold-change $\left(\log ^{2}\right)$. Análise estatística $* p<$ 0,0001 


\subsubsection{Análise da expressão gênica após estímulo com o p69-82 (P3)}

A figura 21 ilustra a diferença de fold-change $\left(\log ^{2}\right)$ dos transcritos gênicos de $I L-15$ (a), IL-15RA (b), IL-1 (c), IL-1RA (d), IL-6 (e) e $I L-8$ (f) observada após interação de células Caco-2 com gliadina e p69-82 (P3) nos tempos de 6, 24 e 48 horas comparadas ao grupo não tratado (NT).

Da interação das células Caco-2 com gliadina para os transcritos do gene $I L-15$ observamos que os valores de fold-change $\left(\log ^{2}\right)$ encontrados foram de 1,97 e 3,15 com valores lineares de 2,94 e 7,90 e $p<0,0001$ quando comparado ao grupo NT, nos tempos de 24 e 48h. Já após a interação com o peptídeo de p69-82 (P3) os valores de fold-change $\left(\log ^{2}\right)$ variaram 3,43 e 3,56, que representam valores lineares de 9,84 e 10,87 mais expressos que o NT nos mesmos tempos com $p<0,0001$ (Figura 21a). Não foi observada modulação dos genes $I L-15 R A$ (Figura 21b).

Os transcritos de $I L-1$ (Figura 21c) apresentaram variação de fold-change $\left(\log ^{2}\right)$ de 1,85 e 1,25 após estímulo com gliadina por 24 e 48 horas, os valores lineares correspondentes obtidos foram 2,62 e 1,37 mais expresso que o NT. Após o estímulo com p69-82 (P3), a variação de fold-change ( $\left.\log ^{2}\right)$ obtida foi 3,09 para o tempo de 24 horas e 2,48 para o tempo de 48 horas, com valores lineares correspondentes a 7,57 e 2,48 respectivamente, mais expressos que o grupo NT e ambos apresentaram valores de $p<0,0001$. Para o receptor $I L-1 R A$ (Figura 21d) somente após 24 horas interação com p69-82 (P3) houve modulação dos transcritos, apresentando variação de fold-change $\left(\log ^{2}\right)$ de 1,02 (linear 1,03). Nos demais tempos, não foi observada modulação dos transcritos de IL-1RA.

IL-6 (Figura 21e) os valores de fold-change ( $\left.\log ^{2}\right)$ após 24 e 48 horas de interação com gliadina modularam os transcritos deste gene com valores de 3,98 e 3,70 e seus correspondentes lineares de 14,86 e 12,05 com valores de $p<0,0001$ quando comparado com NT. No estímulo com p69-82 (P3) os valores de fold-change $\left(\log ^{2}\right)$ foram iguais a 2,81 e 3,64 com valores númericos lineares 6,07 e 11,49 para 24 e 48 horas respectivamente, representando o aumento no número de transcritos dos genes em comparação com o NT ( $p<0,0001)$.

Para os transcritos de $I L-8$ (Figura 21f), apenas no tempo de 24 horas obteve fold-change $\left(\log ^{2}\right)$ 2,48 que corresponde a valor linear numérico de 4,61 e representam o aumento na expressão de transcritos do gene comparado ao grupo NT ( $p<0,0001)$. 

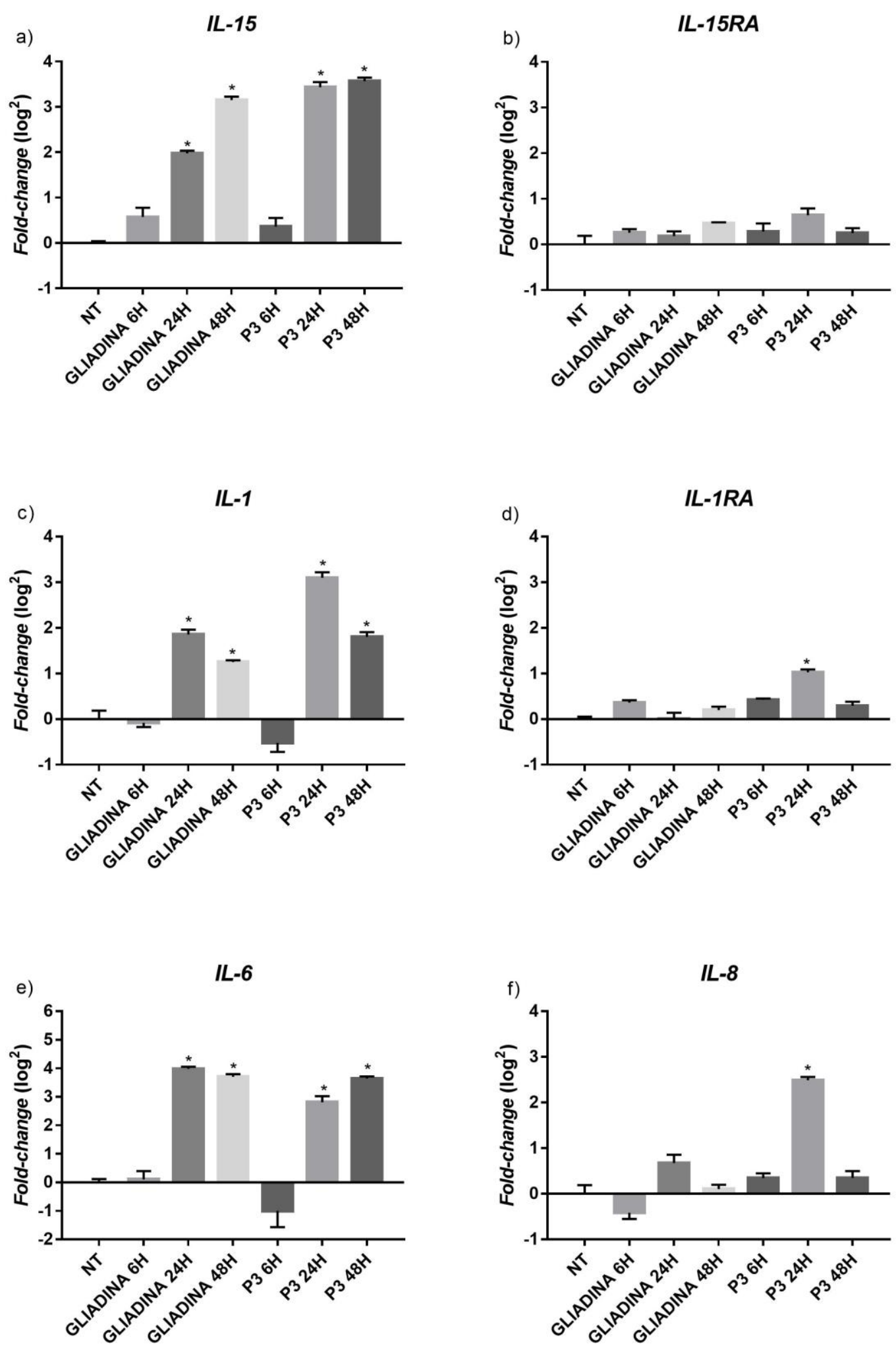

Figura 21 - Modulação da expressão de transcritos gênicos em células Caco-2 estimuladas com gliadina e p69-82 (P3) por 6 horas, 24 horas e 48 horas

Diferenças de fold-change $\left(\log ^{2}\right)$ para os transcritos de $I L-15$ (a), $I L-15 R A$ (b), $I L-1$ (c), $I L-1 R A$ (d), $I L-6$ (e) e $I L-8$ (f)

Os valores representam média e desvio padrão dos fold-change. Análise estatística * $p<0,0001$ 
A figura 22 ilustra a diferença de fold-change $\left(\log ^{2}\right)$ dos transcritos gênicos de TLR-2, TLR-4, iNOS, NFkB, Ocludina e Zonulina obsevada após tempos de 6, 24 e 48 horas de interação com gliadina e p69-82 (P3) comparadas ao grupo não tratado (NT).

Não houve modulação observada em relação ao grupo NT dos transcritos dos genes TLR-2 (Figura 22a), iNOS (Figura 22c) e NFkB (Figura 22d), apresentando todos fold-change $\left(\log ^{2}\right)$ inferior a 1 .

Os transcitos de TLR-4 (Figura 22b) após tempos de 24 e 48 horas de estímulo com gliadina, apresentaram valores de fold-change $\left(\log ^{2}\right)$ de 5,83 e 5,79 com valores lineares numéricos correspondentes a 55,86 e 54,42 ( $p<0,0001)$. Os valores de foldchange $\left(\log ^{2}\right)$ obtidos dos transcritos de TLR-4 após estímulo com p69-82 (P3) foram 4,66 e 5,42 (linear 24,28 e 42,01) para os tempos de 24 e 48 horas respectivamente, evidenciando que este estímulo aumentou o número de transcritos em relação ao NT após os tempos de 24 e 48h $(p<0,0001)$.

Para os transcritos de Ocludina a gliadina apresentou fold-change $\left(\log ^{2}\right)$ de 1,06 e valor linear correspondente de 1,09 apenas após 48h de estímulo. Quando o estímulo foi p69-82 (P3) para Ocludina e Zonulina houve modulação na expressão gênica aumentando o número de transcritos nos tempos de 24 e $48 \mathrm{~h}(p<0,0001)$. Os valores respectivos de fold-change $\left(\log ^{2}\right)$ para Ocludina foram 1,73 e 1,18 (linear 2,32 e 1,27) e para Zonulina 1,41 e 1,16 (linear 2,33 e 1,27) em relação ao NT ( $p<0,0001)$. 

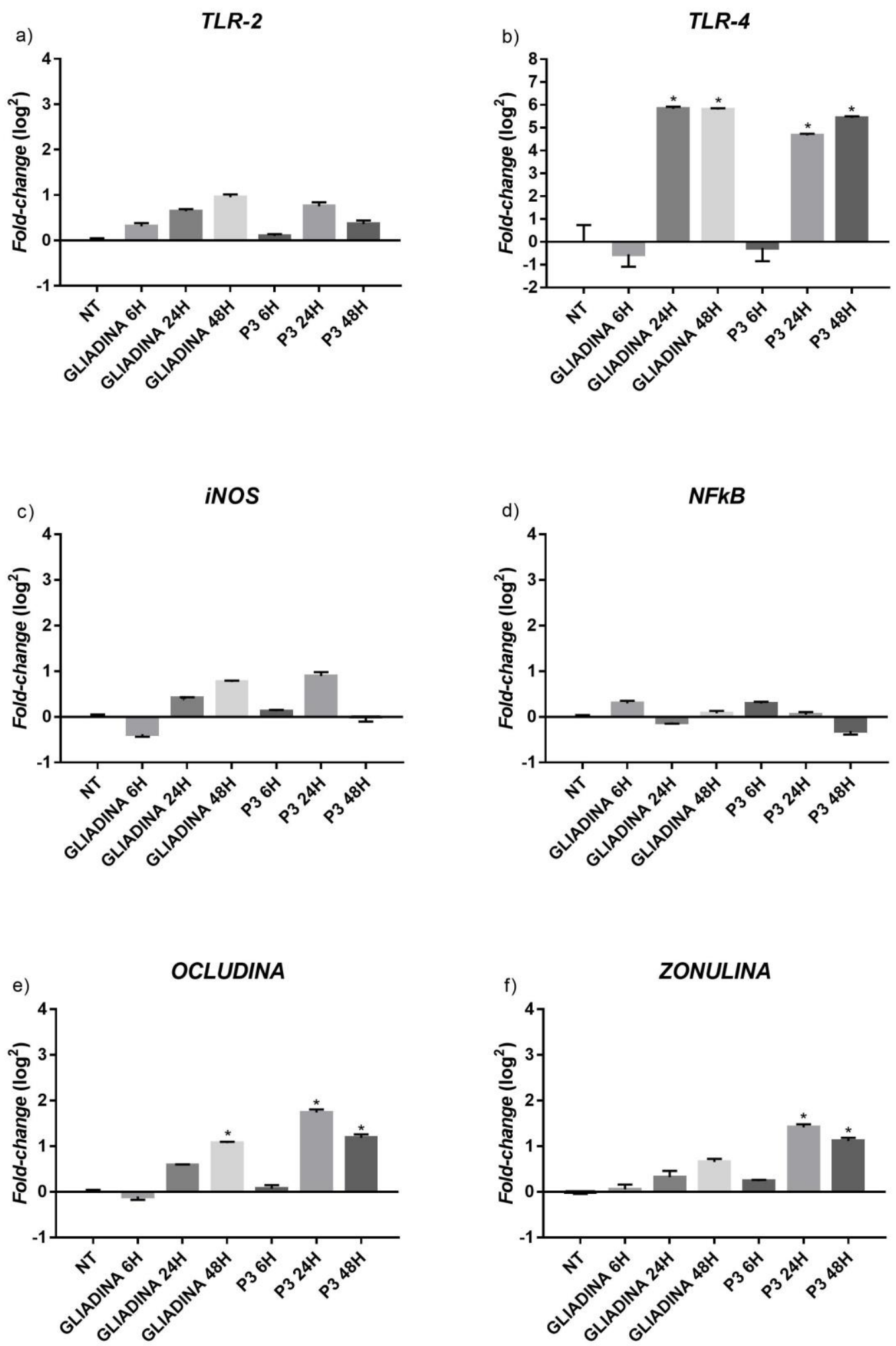

Figura 22 - Modulação da expressão de transcritos gênicos em células Caco-2 estimuladas com gliadina e p69-82 (P3) por 6 horas, 24 horas e 48 horas

Diferenças de fold-change $\left(\log ^{2}\right)$ para os transcritos de TLR-2 (a), TLR-4 (b), iNOS (c), NFkB (d), Ocludina (e) e Zonulina (f) 
Os valores representam média e desvio padrão dos fold-change $\left(\log ^{2}\right)$. Análise estatística $* p<$ 0,0001

\subsubsection{Análise da expressão gênica após estímulo com p31-43 (P4)}

A figura 23 representa a diferença de fold-change $\left(\log ^{2}\right)$ dos transcritos dos genes $I L-15, I L-15 R A, I L-1 A, I L-1 R A, I L-6$ e $I L-8$ observados após a interação de células Caco-2 com gliadina e o peptídeo p31-43 (P4) nos tempos de 6 h, 24 e 48 horas.

Para os transcritos de $I L-15$ (Figura 23a) observa-se que nos tempos de 24 e 48 horas após estímulo com gliadina, os valores de fold-change $\left(\log ^{2}\right)$ obtidos foram de $1,97$ e 3,15 com valores lineares de 2,94 e 7,90 ( $p<0,0001)$. Enquanto a mesma modulação de transcritos gênicos foi observada após o mesmo tempo com o estímulo p31-43 (P4), apresentando diferença de fold-change $\left(\log ^{2}\right)$ de 1,63 e 3,86, que representam um aumento linear na expressão de transcritos de 2,19 e 13,6 ( $p<0,0001)$ em comparação com o NT.

Quanto aos níveis de transcritos do gene $I L-15 R A$ (Figura 23b) e $I L-1 R A$ (Figura 23d), não foram observadas modulações no número de transcritos destes genes superiores 1 de fold-change $\left(\log ^{2}\right)$ quando comparados ao NT.

Os níveis de transcritos de $I L-1$ após receberem estímulo de gliadina apresentaram fold-change $\left(\log ^{2}\right)$ de 1,85 e 1,25 para os tempos de 24 e 48 horas, que representam valores lineares de 2,62 e 1,37 ( $p<0,0001)$. Quando o estímulo recebido foi p31-43 (P4) os valores de fold-change ( $\left.\log ^{2}\right)$ obtidos para os tempos de 24 e 48 horas, foram 1,9 e 2,42 respectivamente, que correspondem a valores lineares de 2,96 e 4,37 e representam aumento no número de transcritos em relação ao NT $(p<0,0001)$ (Figura 23d).

Os níveis dos transcritos de $I L-6$ após estímulo de gliadina apresentaram foldchange $\left(\log ^{2}\right)$ de 3,98 e 3,70 (valor linear numérico de 14,86 e 12,05) ( $p<0,0001$ ). Quando o estímulo foi p31-43 (P4) os valores de fold-change $\left(\log ^{2}\right)$ foram de 1,49 e 3,46 com valores lineares de 1,83 e 10,09 mais expressos quando comparado com não tratado para os tempos de 24 h e 48 horas ( $p<0,0001$ ), como apresentado na Figura $23 \mathrm{e}$.

Para os transcritos do gene $I L-8$ apena o p31-43 (P4) apresentou fold-change $\left(\log ^{2}\right)$ com valores de 1,02, 1,42 e 1,28 para os tempos de 6, 24 e 48 h respectivamente, que representam valores lineares correspondentes de 1,03, 1,69 e 1,44 na expressão dos 
transcritos deste gene em relação ao NT (Figura 23f), com $p<0,0001$ em todos os tempos avaliados. 

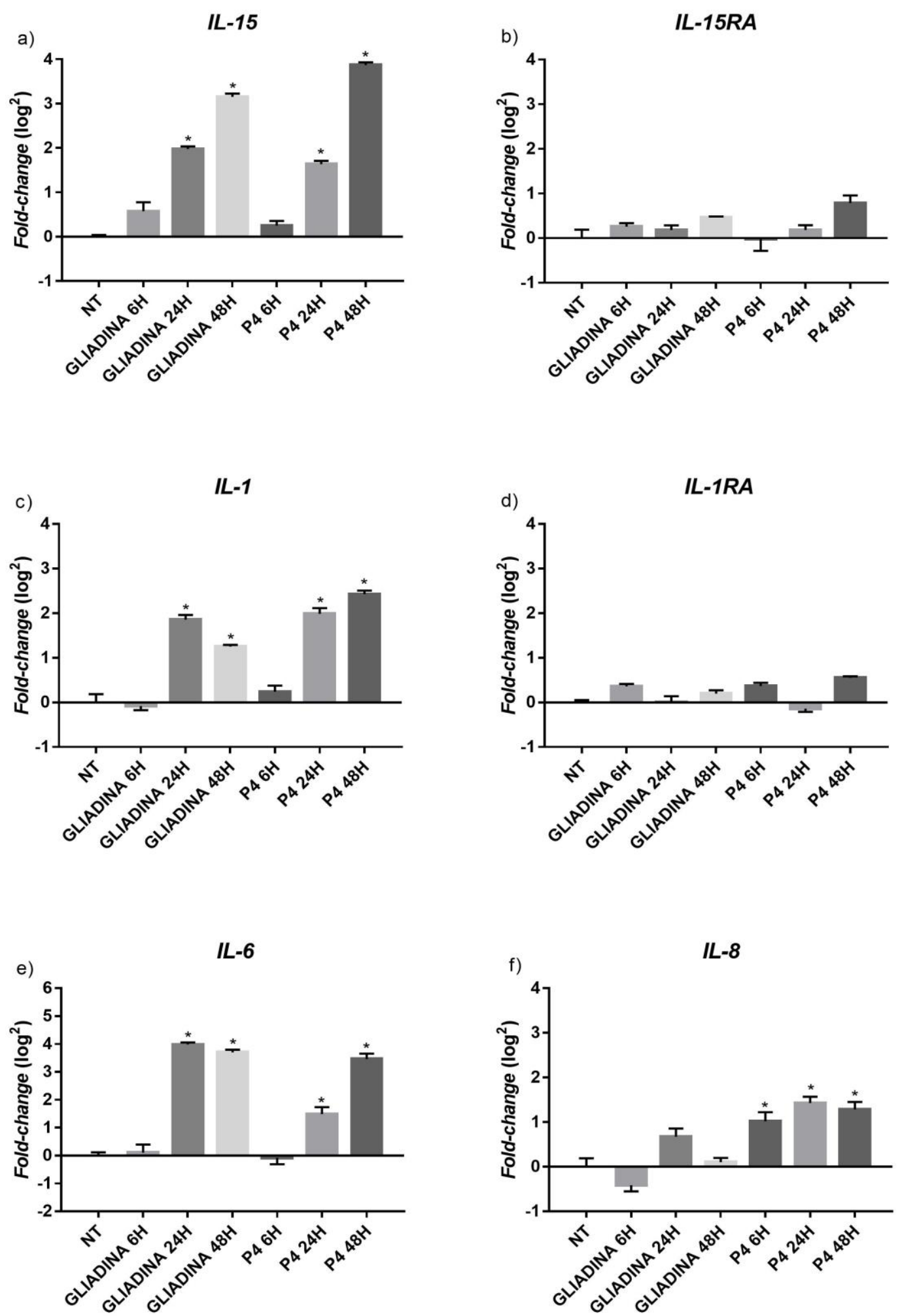

Figura 23 - Modulação da expressão de transcritos gênicos em células Caco-2 estimuladas com gliadina e p31-43 (P4) por 6 horas, 24 horas e 48 horas

Diferenças de fold-change ( $\left.\log ^{2}\right)$ para os transcritos de $I L-15$ (a), IL-15RA (b), IL-I (c), IL-IRA (d), $I L-6$ (e) e $I L-8$ (f)

Os valores representam média e desvio padrão dos fold-change $\left(\log ^{2}\right)$. Análise estatística $* p$ 0,0001 
Os transcritos de TLR-2, TLR-4, iNOS, NFKB, Ocludina e Zonulina estão representados na figura 24.

Em comparação ao observado nas células não tratadas, não houveram modulações nos níveis dos transcritos dos genes TLR-2 (Figura 24a), iNOS (Figura 24c) e $N F \kappa B$ (Figura 24d).

Já para os transcritos do gene TLR-4 quando o estímulo foi gliadina os valores de fold-change $\left(\log ^{2}\right)$ observados nos tempos de 24 e $48 \mathrm{~h}$ foram 5,83 e 5,79 com valores lineares de 55,86 e 54,42 ( $p<0,0001)$. Quando o peptídeo p31-43 (P4) foi usado como estímulo, foram observados fold-change $\left(\log ^{2}\right)$ de 1,68 para 6 horas, 2,92 para 24 horas e 5,76 para 48 horas, o que em valores lineares representa alteração de 2,12, 6,52 e 53,49 respectivamente, na expressão do número de transcritos em comparação com o NT (Figura 24b).

Para os transcritos de Ocludina a gliadina apresentou fold-change $\left(\log ^{2}\right)$ de 1,06 e valor linear correspondente de 1,09 equanto que para o estímulo de p31-43 (P4) o fold-change $\left(\log ^{2}\right)$ diferenciou 1,26 (linear 1,40) após 48 horas de estímulo (Figura 24e).

Quando o estímulo foi p31-43 (P4) para Zonulina houve modulação na expressão gênica aumentando o número de transcritos nos tempos de 48h $(p<0,0001)$, os valores respectivos de fold-change $\left(\log ^{2}\right)$ foram 1,37 (linear 1,59) $(p<0,0001$ ) (Figura 24f). 

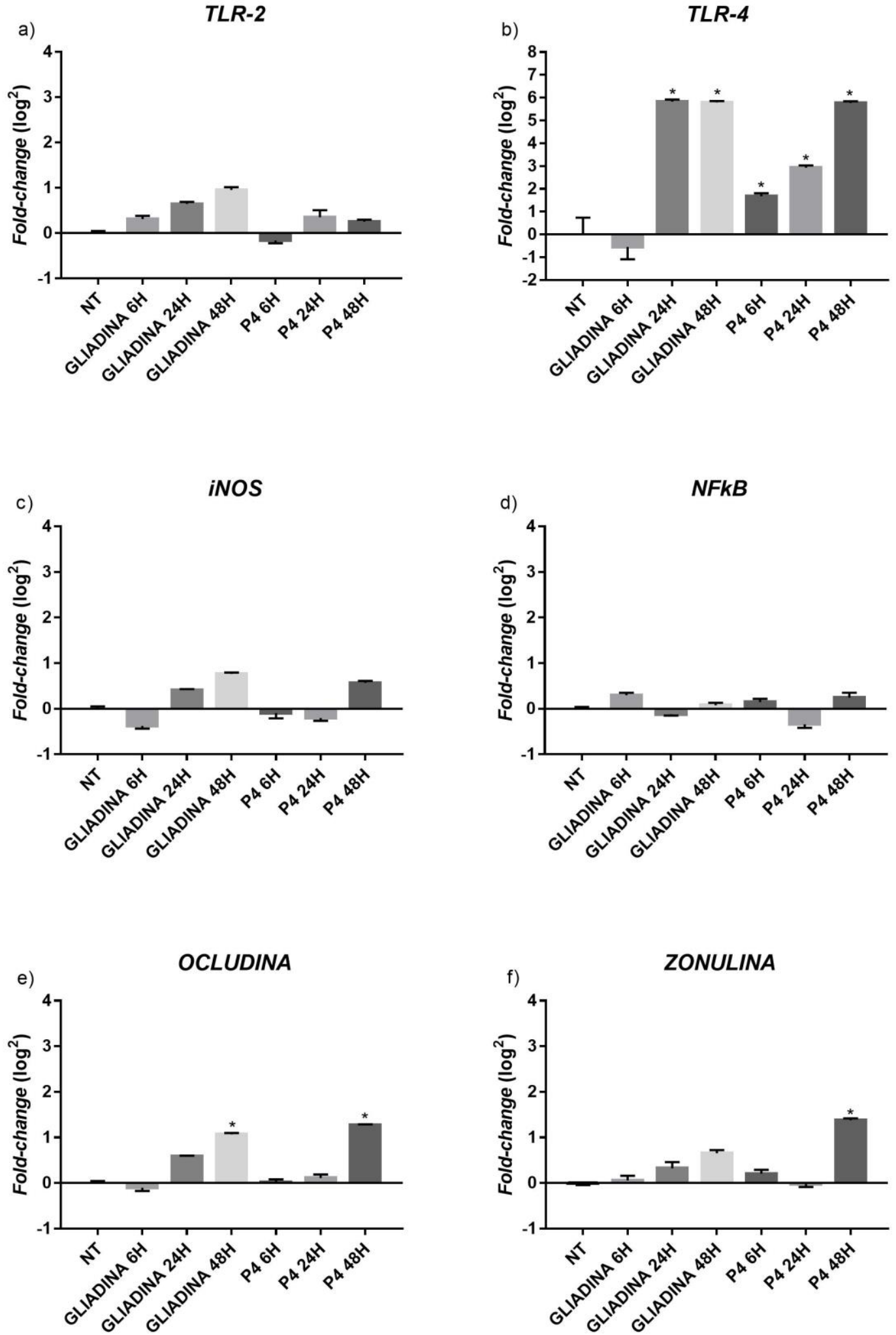

Figura 24 - Modulação da expressão de transcritos gênicos em células Caco-2 estimuladas com gliadina e p31-43 (P4) por 6 horas, 24 horas e 48 horas

Diferenças de fold-change ( $\left(\log ^{2}\right)$ para os transcritos de TLR-2 (a), TLR-4 (b), iNOS (c), NFkB (d), Ocludina (e) e Zonulina (f)

Os valores representam média e desvio padrão dos fold-change $\left(\log ^{2}\right)$. Análise estatística $* p<$ 0,0001 


\subsubsection{Análise da expressão gênica após estímulo com o P57-68E 65 (P5)}

A figura 25 ilustra a variação de fold-change $\left(\log ^{2}\right)$ observada da interação de células Caco-2 com gliadina e peptídeo p57-68E 65 (P5) após 6, 24 e 48 horas de interação.

As diferenças de fold-change $\left(\log ^{2}\right)$ observadas para os transcritos de $I L-15$ (Figura 25a) que foram estimulados com gliadina nos tempos de 24 e 48 horas, geraram valores de fold-change $\left(\log ^{2}\right)$ de 1,97 e 3,15 que representam valores lineares de 2,94 e 7,90 ( $p<0,0001)$. Após a interação com o peptídeo p57-68E 65 (P5), foram obtidos valores de fold-change $\left(\log ^{2}\right)$ de 1,83 e 3,76 (linear 2,57 e 12,62) comparados ao grupo não tratado (Figura 25a). Em ambos os estímulos se observa um aumento gradativo no número de transcritos ao longo do tempo. Já para seu receptor, IL-15RA (Figura 25b), os transcritos não apresentaram modulação em relação ao grupo NT.

Para os transcritos de $I L-1$ (Figura 25c), os valores de fold-change $\left(\log ^{2}\right)$ para gliadina após estímulo de 24 e 48 horas foram de 1,85 e 1,25 com valores lineares de 2,62 e 1,37. Após estímulo com p57-68E 65 (P5) para os tempos de 24 e de 48 horas $(p<$ 0,0001) os valores de fold-change $\left(\log ^{2}\right)$ foram de 2,21 e 2,56, que representam valores lineares 3,63 e 4,90 mais expressos que os valores observados no grupo não tratado. Para o receptor $I L-1 R A$ (Figura 25d), os transcritos não apresentaram modulação em relação ao grupo NT.

Para os transcritos do gene $I L-6$, as diferenças de fold-change $\left(\log ^{2}\right)$ geradas na interação com o estímulo gliadina apresentaram valores de 3,98 e 3,7 nos tempos de 24 e 48h, que representam valores lineares de 14,86 e 12,05 ( $p<0,0001)$ maiores que o NT. Após estímulo com p57-68E65 (P5) nos tempos de 24 e 48 horas, os valores de foldchange $\left(\log ^{2}\right)$ 1,66 e 2,95 com valores lineares 2,17 e 6,79 foram mais expressos em relação ao NT, respectivamente ( $p<0,0001)$ (Figura 25e).

Para os transcritos de $I L-8$ (Figura 25f), as diferenças de fold-change $\left(\log ^{2}\right)$ para p57-68 $\mathrm{E}_{65}$ (P5) após 6, 24 e 48 horas de interação apresentaram valores de 1,06, 1,33 e 1,02, que representam valores lineares $1,12,1,76$ e 1,04 mais expressos que o grupo NT para este gene. 

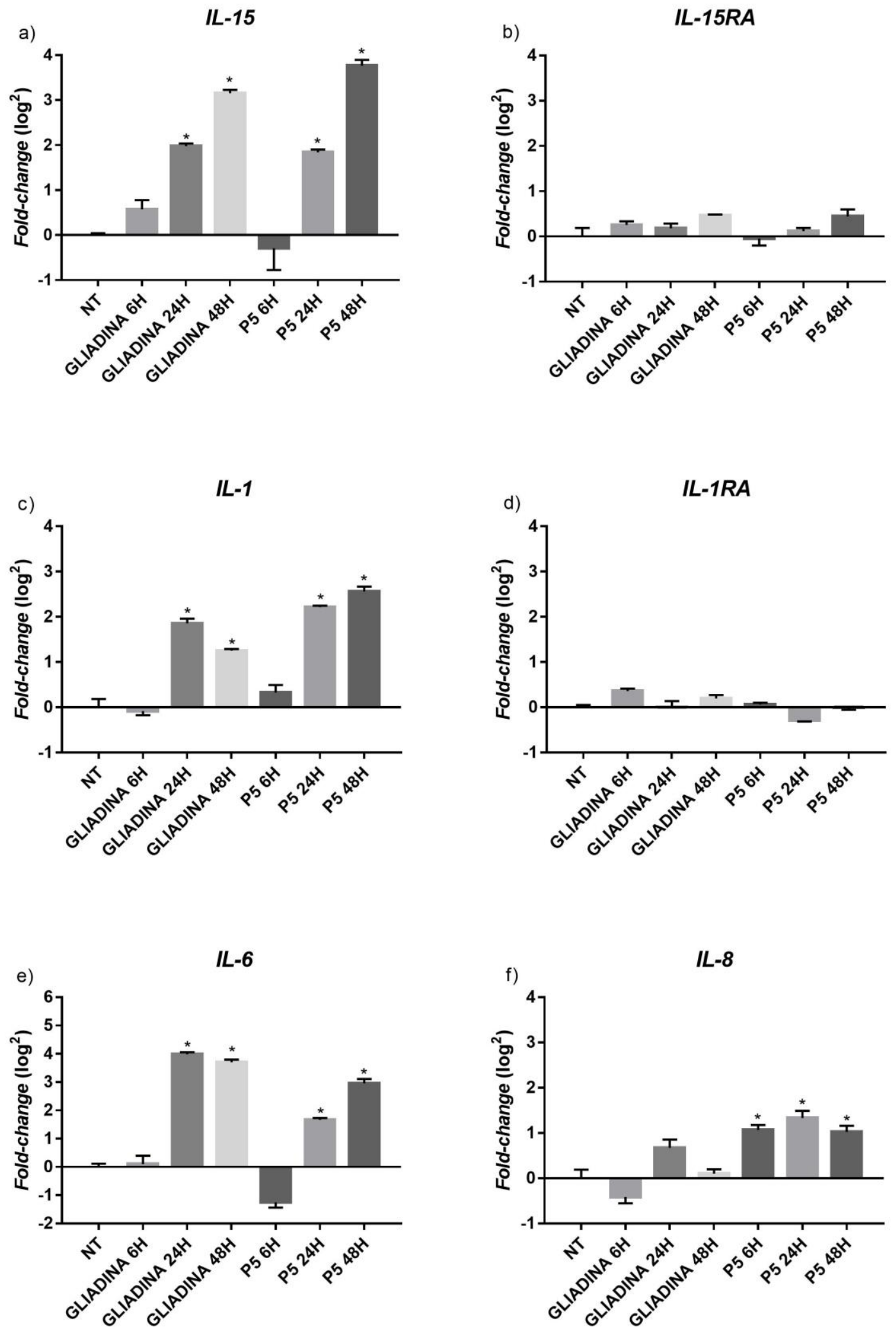

Figura 25 - Modulação da expressão de transcritos gênicos em células Caco-2 estimuladas com gliadina e p57-68 65 (P5) por 6 horas, 24 horas e 48 horas

Diferenças de fold-change ( $\log ^{2}$ ) para os transcritos de $I L-15$ (a), IL-15RA (b), IL-1 (c), IL-1RA (d), $I L-6$ (e) e $I L-8$ (f)

Os valores representam média e desvio padrão dos fold-change $\left(\log ^{2}\right)$. Análise estatística $* p<$ 0,0001 
As diferenças de fold-change $\left(\log ^{2}\right)$ observadas para os transcritos de TLR-2, TLR-4, iNOS, NFkB, Ocludina e Zonulina gerados na interação com gliadina e p57$68 \mathrm{E}_{65}$ (P5) estão representados na figura 26.

Em comparação ao observado nas células não tratadas, não foram houveram modulações nos níveis dos transcritos do gene TLR-2 (Figura 26a), iNOS (Figura 26c), $N F \kappa B$ (Figura 26d), Ocludina (Figura 26e), e Zonulina (Figura 26f).

Nos transcritos gênicos para TLR-4 (Figura 26b), as diferenças de fold-change $\left(\log ^{2}\right)$ para gliadina foram 5,83 e 5,79 nos tempos de 24 e 48 horas, apresentando valores numéricos lineares de 55,86 e 54,42 mais expressos que o grupo NT para este gene. Após a interação com o estímulo p57-68E65 (P5) nos tempos de 24 e 48 horas, foram observados valores de fold-change $\left(\log ^{2}\right)$ de 3,59 e 4,84 com valores lineares correspondentes de 10,69 e 27,63 mais expressos que os valores obtidos no grupo NT, todos com $p<0,0001$. 

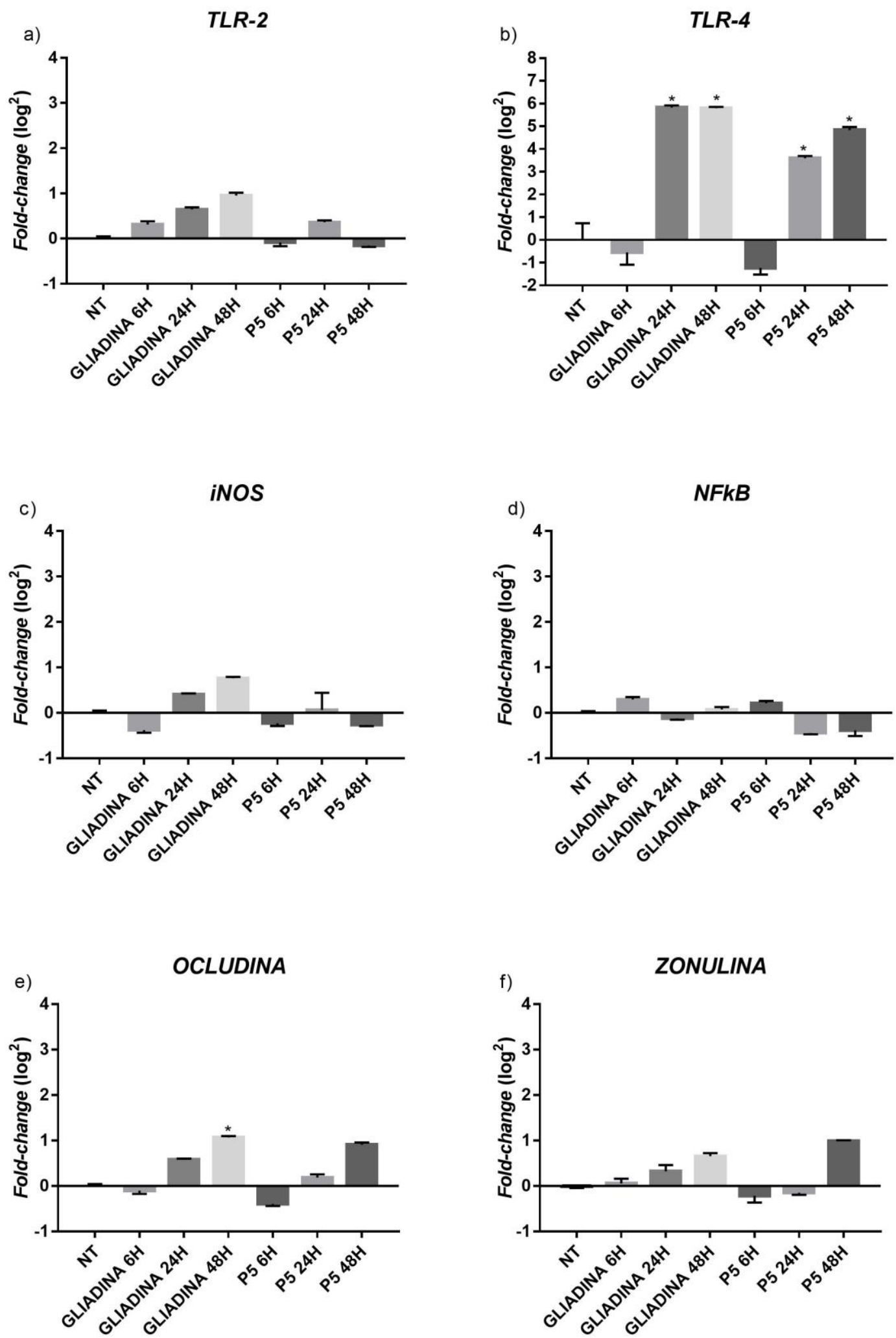

Figura 26 - Modulação da expressão de transcritos gênicos em células Caco-2 estimuladas com gliadina e $\mathrm{p} 57-68 \mathrm{E}_{65}(\mathrm{P} 5)$ por 6 horas, 24 horas e 48 horas

Diferenças de fold-change ( $\left.\log ^{2}\right)$ para os transcritos de TLR-2 (a), TLR-4 (b), iNOS (c), NFkB (d), Ocludina (e) e Zonulina (f)

Os valores representam média e desvio padrão dos fold-change $\left(\log ^{2}\right)$. Análise estatística ${ }^{*} p<$ 0,0001 


\subsubsection{Análise da expressão gênica após estímulo com p69-82E 72 (P6)}

As diferenças de fold-change $\left(\log ^{2}\right)$ para os transcritos observadas na interação com gliadina e o peptídeo p69-82 $\mathrm{E}_{72}$ (P6) com células Caco-2 durante tempos de 6, 24 e 48 horas, estão ilustradas na figura 27.

Para os transcritos de $I L-15$ (Figura 27a) os tempos de 24 e de 48 horas foram diferentemente expressos em relação so grupo NT sendo que ambos foram estatisticamente significantativos apresentando valores ajustados de $p<0,0001$. Após estímulo com glaidina observamos valores de fold-change $\left(\log ^{2}\right)$ de 1,97 e 3,15 (lineares 2,94 e 7,9 respectivamente), enquanto que para a interação com p69-82 $\mathrm{E}_{72}$ (P6) a variação de fold-change $\left(\log ^{2}\right)$ foi de 2,10 e 3,61 com valores lineares correspondentes de 3,31 e 11,26 aumentados em relação ao grupo NT.

Não foram observadas modulações nos níveis dos transcritos do gene $I L-15 R A$ (Figura 27b) e IL-1RA (Figura 27c) para a interação de células Caco-2 com o peptídeo p69-82 $\mathrm{E}_{72}(\mathrm{P} 6)$.

Para os transcritos da $I L-1$ os valores de fold-change $\left(\log ^{2}\right)$ para os tempos de 24 horas e 48 horas foram 1,85 e 1,25 com valores lineares de 2,62 e 1,37 após estímulo com gliadina. Quando o estímulo foi 669-82 $\mathrm{E}_{72}$ (P6), os valores encontrados foram foldchange $\left(\log ^{2}\right)$ 1,87 e 2,24 (linear 2,66 e 3,72) mais expressos que o grupo NT.

Os transcritos de $I L-6$ (Figura 27e) para o tempo de 24 e 48 horas apresentaram valores de fold-change $\left(\log ^{2}\right)$ 3,98 e 3,70 com valores lineares de 14,86 e 12,05 para o estímulo de glaidina. Quando estimulamos com p69-82 $\mathrm{E}_{72}$ (P6) apenas o tempo de $48 \mathrm{~h}$ modulou o gene, com fold-change $\left(\log ^{2}\right)$ de 2,88 e valor linear 6,41 , indicando quanto mais expresso encontra-se o gene em relação ao grupo NT $(p<0,0001)$.

Para os transcritos de $I L-8$ (Figura 27f), a diferença de fold-change $\left(\log ^{2}\right)$ foi de 1,03 com valor linear de 1,08 quando estimulado com p69-82 $\mathrm{E}_{72}$ (P6) pontualmente em 48h de estímulo $(p<0,0001)$. 

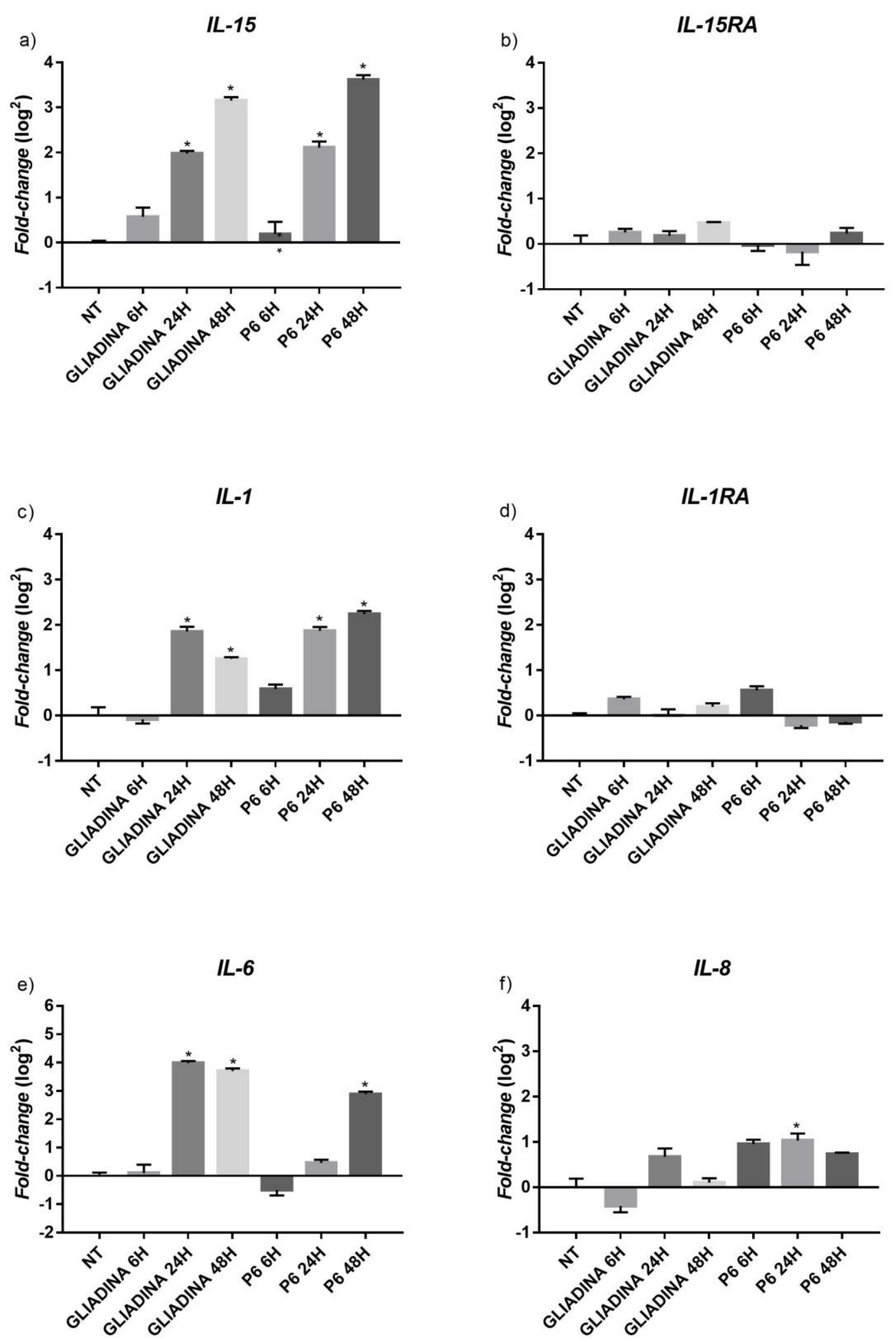

Figura 27 - Modulação da expressão de transcritos gênicos em células Caco-2 estimuladas com gliadina e p69-82 $\mathrm{E}_{72}$ (P6) por 6 horas, 24 horas e 48 horas

Diferenças de fold-change ( $\log ^{2}$ ) para os transcritos de IL-15 (a), IL-15RA (b), IL-1 (c), IL-1RA (d), IL-6 (e) e IL-8 (f) 
Os valores representam média e desvio padrão dos fold-change $\left(\log ^{2}\right)$. Análise estatística $* p<$ 0,0001

As diferenças de fold-change $\left(\log ^{2}\right)$ observadas para os transcritos de TLR-2, TLR-4, iNOS, NFkB, Ocludina e Zonulina gerados na interação com gliadina e p69$82 \mathrm{E}_{72}$ (P6) estão representados na figura 28.

Os transcritos de TLR-4 (Figura 28b) após a interação com gliadina apresentaram valores de fold-change $\left(\log ^{2}\right)$ de 5,83 e 5,79 que correspondem a valores lineares de 55,86 e 54,42 nos tempos de 24 e 48h ( $p<0,0001)$. Após a a interação com P69-82E 72 nos tempos de 24 e 48 horas, os valores de fold-change $\left(\log ^{2}\right)$ observadas foram de 1,88 e 5,40, com valores lineares de 2,83 e 41,51, que representam quantas vezes mais expressos que o grupo NT está este gene.

Nos transcritos de TLR-2 (Figura 28a) iNOS (Figura 28c), Ocludina (Figura 28e) e Zonulina (Figura 28f), quando estimulados com p68-82 $\mathrm{E}_{72}$, os valores de foldchange $\left(\log ^{2}\right)$ não apresentaram modulação gênica em relação ao NT. 

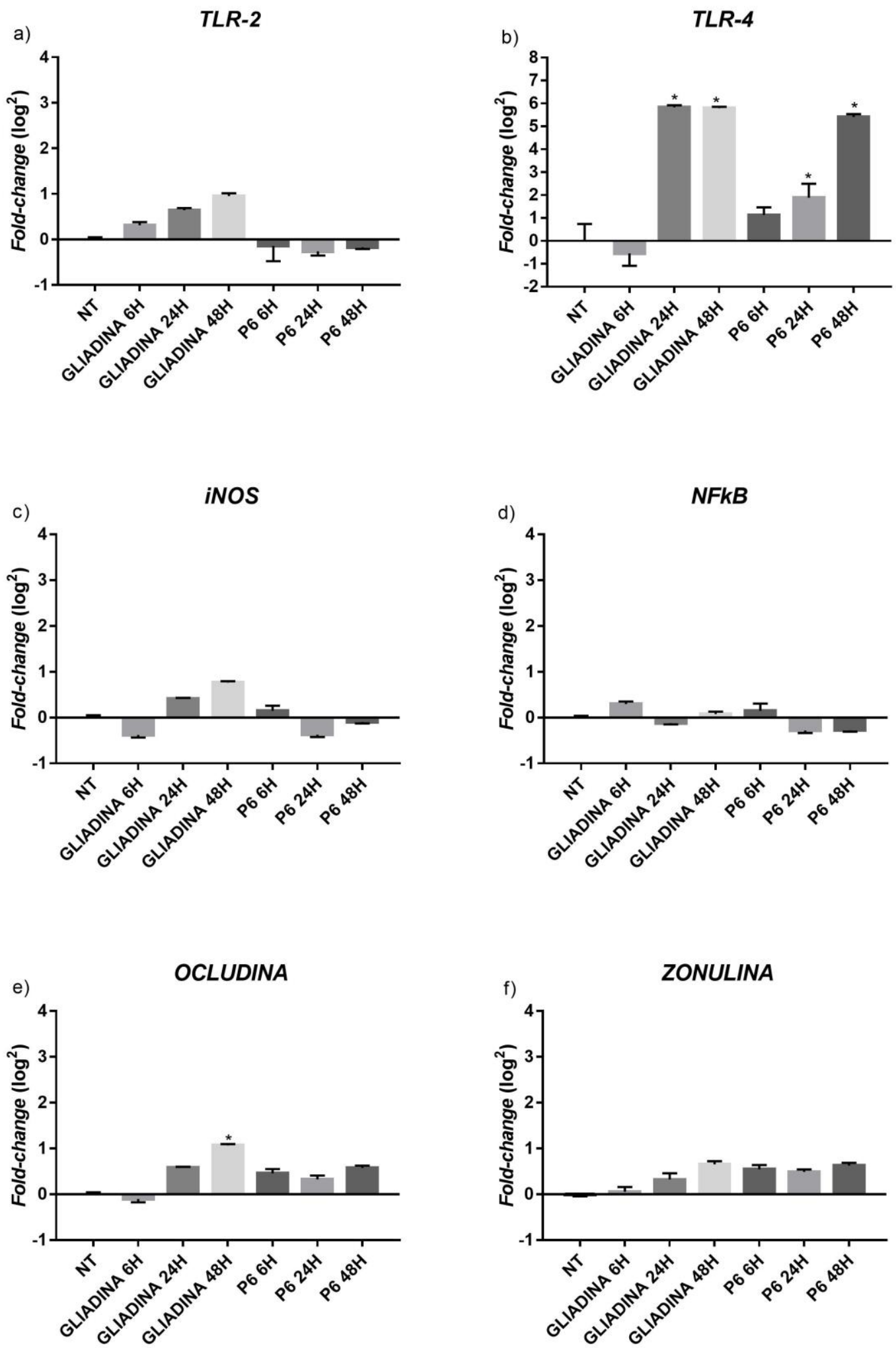

Figura 28 - Modulação da expressão de transcritos gênicos em células Caco-2 estimuladas com gliadina e p69-82 $\mathrm{E}_{72}$ (P6) por 6 horas, 24 horas e 48 horas

Diferenças de fold-change ( $\left.\log ^{2}\right)$ para os transcritos de TLR-2 (a), TLR-4 (b), iNOS (c), NFkB (d), Ocludina (e) e Zonulina (f) após interação de células Caco-2 com gliadina e p69-82E $\mathrm{E}_{72}$ (P6) Os valores representam média e desvio padrão dos fold-change. Análise estatística $* p<0,0001$ 


\subsubsection{Dosagem de Óxido Nítrico}

\subsubsection{1. Óxido Nítrico}

Para a dosagem de óxido nítrico foi empregado o método de Griess para todos os sobrenadantes de cultura que receberam estímulo de LPS, gliadina ou um dos peptídeos (P1 a P6) após tempo de 6, 24 e 48 horas de interação com células Caco-2. O óxido nítrico foi quantificado em $\mu \mathrm{mol} / \mathrm{L}$, determinado por regressão linear em curva padrão de diluição seriada de nitríto de sódio.

Os resultados observados mostram que a dosagem de óxido nítrico foi compatível com o padrão de expressão de transcritos dos genes das citocinas inflamatórias $I L-15, I L-1$ e $I L-6$, para os tempos de 24 e 48 horas após estimulados com LPS, gliadina e peptídeos (P1-P6), demonstrando que essa modulação gênica promoveu a produção de óxido nítrico pelas células Caco-2 após a cinética de tempo.

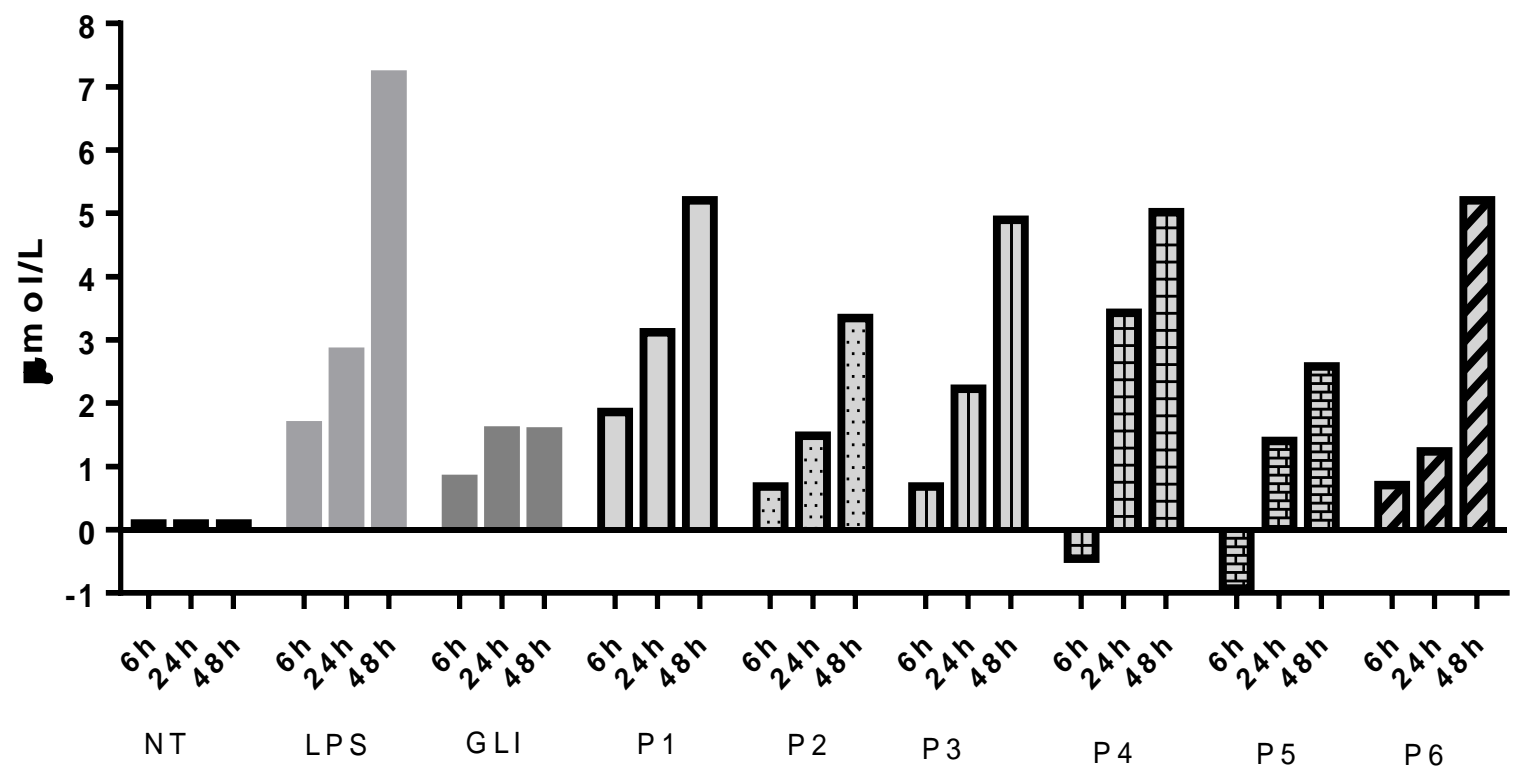

Figura 29 - Dosagem de Óxido Nítrico (NO) em sobrenadante de cultura de célulasCaco-2 após interação com LPS, gliadina e seus peptídeos em 6, 24 e 48h 


\subsubsection{Dosagem das Citocinas}

\subsubsection{Dosagem de IL-6}

A dosagem da citocina IL-6 produzida durante a interação de células Caco-2 com LPS, gliadina e peptídeos (P1-P6) após 6, 24 e 48 horas, correspondem aos resultados da expressão gênica realizada anteriormente. Como pode ser observado na figura 30, a quantidade dosada de IL-6, tal qual a expressão dos transcritos do gene da $I L-6$, foram tempo dependente, evidenciando um aumento gradual da quantidade de IL6 observada ao longo dos tempos, quando comparadas ao NT.

A presença desta citocina reflete o estado inflamatório provocado pelos estímulos nas células Caco-2 quando comparados aos níveis dessa interleucina nas células não tratadas. Como era esperado, o estímulo inflamatório inespecífico LPS apresentou resultados semelhante aos obtidos com a gliadina.

Quando comparamos os níveis de IL-6 presente nos sobrenadantes das células estimuladas com os peptídeos P1 e P2 com gliadina e LPS, observamos um comportamento muito semelhante com presença de resposta inflamatória evidente.

Entretanto quando comparamos as formas desamidadas destes peptídeos (P5 e P6) com a gliadina, observamos que em 24 horas após estímulo, a produção da citocina IL-6 é inferior a gerada pela gliadina, mas que em 48 horas esses valores são mais elevados que os gerados pela gliadina. O comportamento de P3 foi semelhante ao da gliadina e de P1 e P2, e o peptídeo P4 foi semelhante aos peptídeos desamidados P5 e P6. 


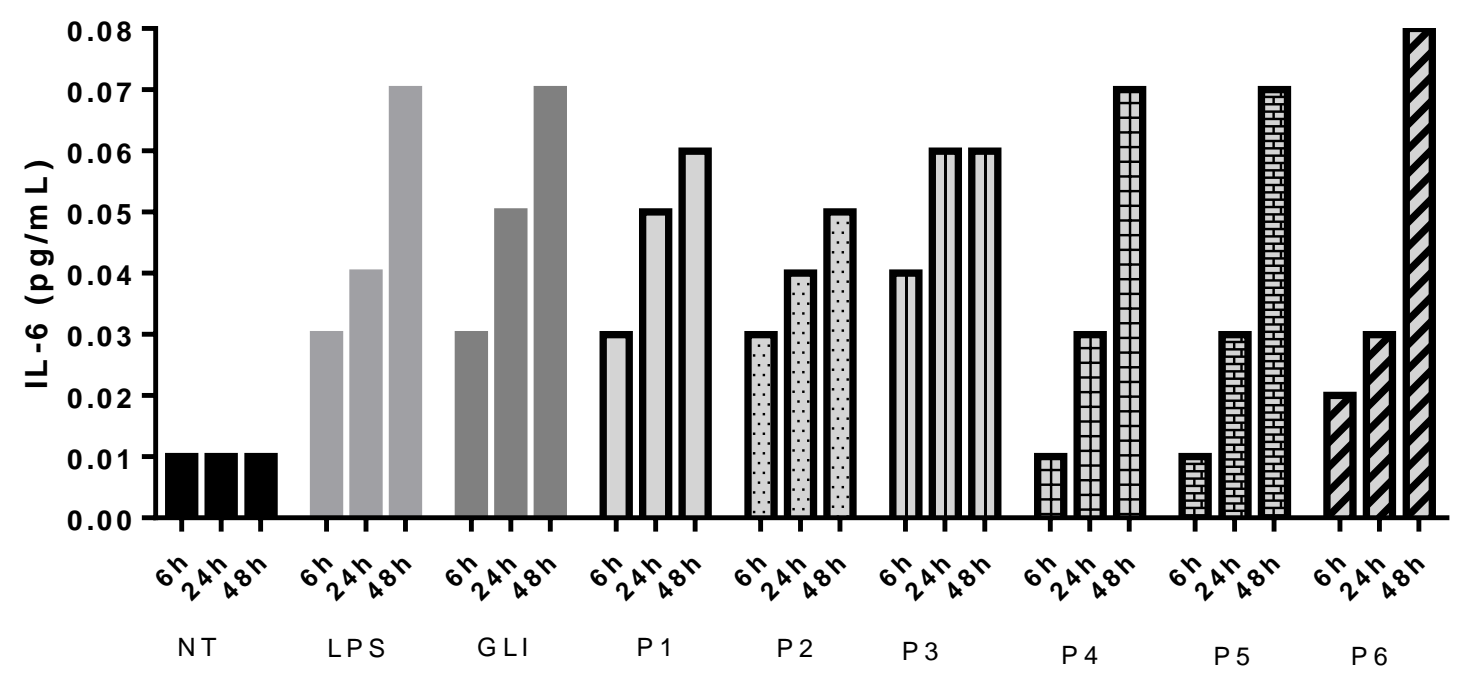

Figura 30 - Dosagem da citocina Interleucina 6 (IL-6) em sobrenadante de cultura de células Caco-2 após interação com LPS, gliadina e seus peptídeos em 6, 24 e 48h

\subsubsection{Dosagem de IL-21}

A Interleucina 21 (IL-21) é um membro da família de citocinas tipo-I, e estruturalmente mostra homologia coma as interleucinas IL-2, IL-4 e IL-15 ao compartilhar a cadeia gama com estas citocinas. A produção da citocina IL-21 foi observada na interação das células Caco-2 com LPS, gliadina e peptídeos, nos tempos propostos por este estudo. Por homologia com a cadeia gama da IL-15, infere-se que a quantidade dosada de citocina IL-21 foi tão representativa quanto a expressão dos transcritos gênicos para $I L-15$ nos tempos de 6, 24 e 48 horas.

As interações propostas por este estudo, demonstraram ser potentes indutoras da expressão da citocina inflamatória IL-21 (Figura 31), especialmente nos tempos de 24 e 48 horas quando comparadas com o NT. Observa-se ainda, comportamento semelhante de produção de IL-21 nos peptídeos P1, P4 e P6 quando comparados com LPS e gliadina.

O peptídeo desamidado P6 apresentou maior quantidade de IL-21 em 6 e 48 horas quando comparado ao seu peptídeo homologo não desamidado P2. O peptídeo P3 foi o que demonstrou maior quantidade de IL-21 no tempo de 24 horas quando comparada aos demais peptídeos no mesmo tempo. Em 48 horas de interação, os peptídeos P1, P4 e P6 presentaram os maiores níveis de IL-21, quando comparados aos 
demais peptídeos no mesmo tempo. Em todas as interações observa-se quantidade de IL-21 crescente ao longo do tempo, quando comparada ao NT.

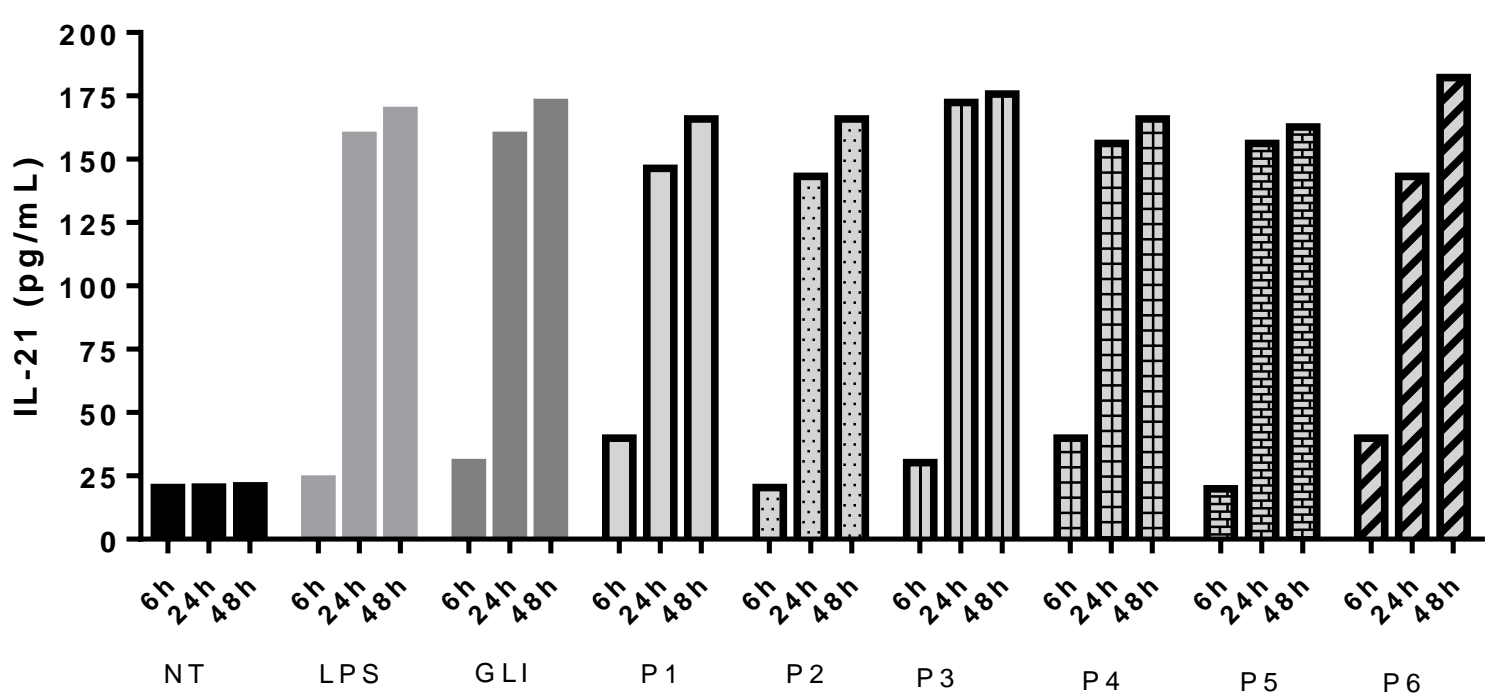

Figura 31 - Dosagem da citocina Interleucina 21 (IL-21) em sobrenadante de cultura de células Caco-2 após interação com LPS, gliadina e seus peptídeos em 6, 24 e 48h

\subsubsection{Dosagem de $I L-2$}

A Interleucina 2 (IL-2) exerce papel fundamental na ativação e proliferação de linfócitos, assim como na expansão das células $\mathrm{T}$, células NK e células $\mathrm{B}$, durante a resposta inflamatória.

Assim como para IL-21, a IL-2 refletem a expressão dos transcritos gênicos observados para IL-15. A indução da produção de IL-2 pelas células Caco-2 durante a interação com o LPS, gliadina e peptídeos, mostrou-se ser elevada e tempo dependente (Figura 32).

Quando comparado aos níveis de IL-2 das células que não receberam tratamento, a indução de IL-2 atingiu maior quantidade dosada no tempo de 6 horas de interação com o peptídeo P6, seguido de seu homologo não desamidado P3. Porém, no tempo de 24 e de 48 horas de interação, os níveis mais elevados foram observados para 
P2. Todos os peptídeos mostraram-se tão eficientes quanto a gliadina e LPS para produzir IL-2.

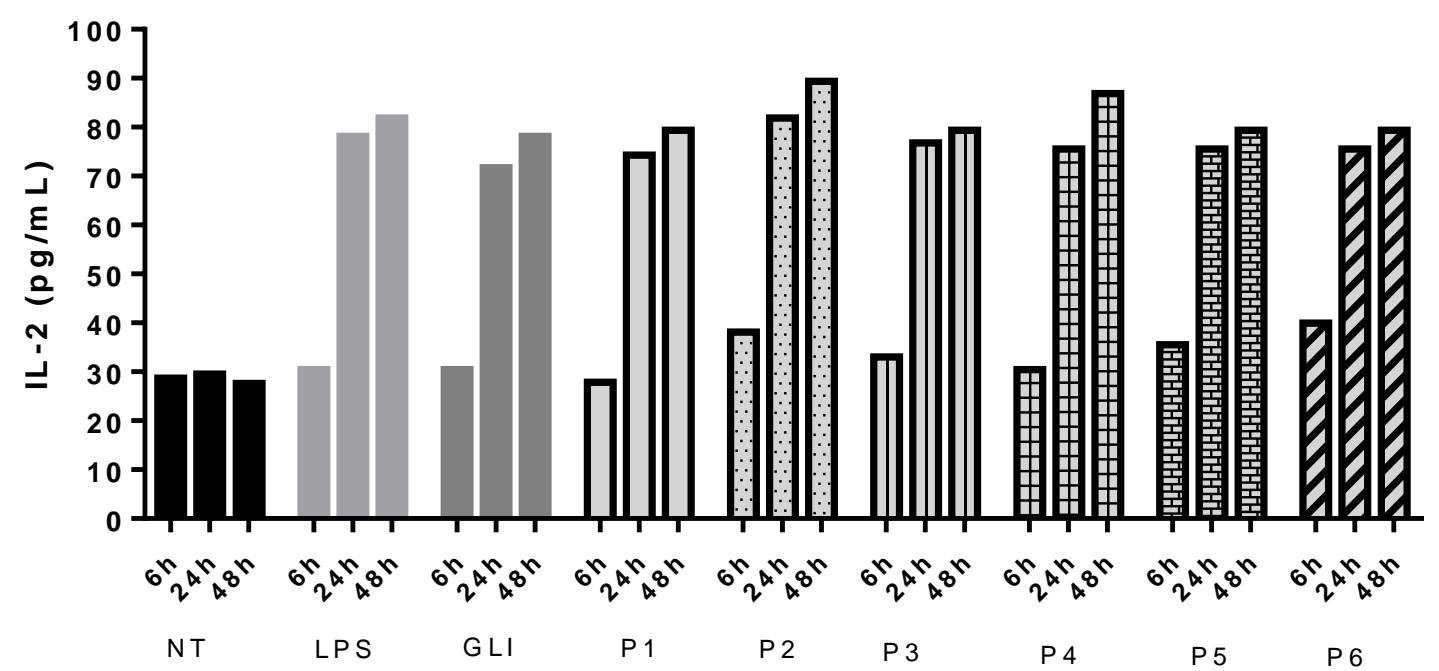

Figura 32 - Dosagem da citocina Interleucina 2 (IL-2) em sobrenadante de cultura de células Caco-2 após interação com LPS, gliadina e seus peptídeos em 6, 24 e 48h

\subsubsection{Dosagem de IL-8}

A Interleucina 8 (IL-8) estimula seletivamente a habilidade dos neutrófilos e linfócitos T de infiltrarem-se em tecido inflamado ou danificado. Quando na presença de estímulo exógeno a IL-8 é secretada por tipos diferentes de células, como por exemplo, epiteliais e células sanguíneas.

No presente estudo a produção de IL-8 ficou evidenciada quando células Caco2 foram estimuladas com LPS, gliadina e peptídeos de gliadina. Ao contrário das outras interleucinas dosadas por este estudo, a quantidade de IL-8 presente nos estímulos não foi tempo dependente (Figura 33).

Assim como observado para os transcritos gênicos de $I L-8$, para todos os estímulos, observa-se maior pico dosado da citocina no tempo de 24 horas, quando comparado com NT. O estímulo LPS apresentou as maiores quantidades dosadas para os tempos de 6, 24 e 48 horas, enquanto que gliadina apresentou níveis menores de produção desta citocina em relação aos demais estímulos com peptídeos (P1-P6). 
Embora, todos os estímulos exibissem o mesmo comportamento em relação ao tempo de 24 horas de interação com as células, os estímulos LPS, P2, P5 e P6 apresentaram em 48 horas níveis de IL-8 menores do que observado inicialmente com 6 horas de estímulos. Nesses estímulos observa-se níveis já elevados em 6 horas seguidos de aumento dos níveis em 24 horas e, então, queda dos níveis em 48 horas para quantidades menores que as observadas em 6 horas.

Nas células estimuladas com gliadina, P1 e P3 observa-se que os níveis dosados após 48 horas apresentaram-se mais elevados que os observados em 6 horas de estímulo, enquanto que para P4, os níveis em 6 horas e 48 horas são aproximadamente iguais.

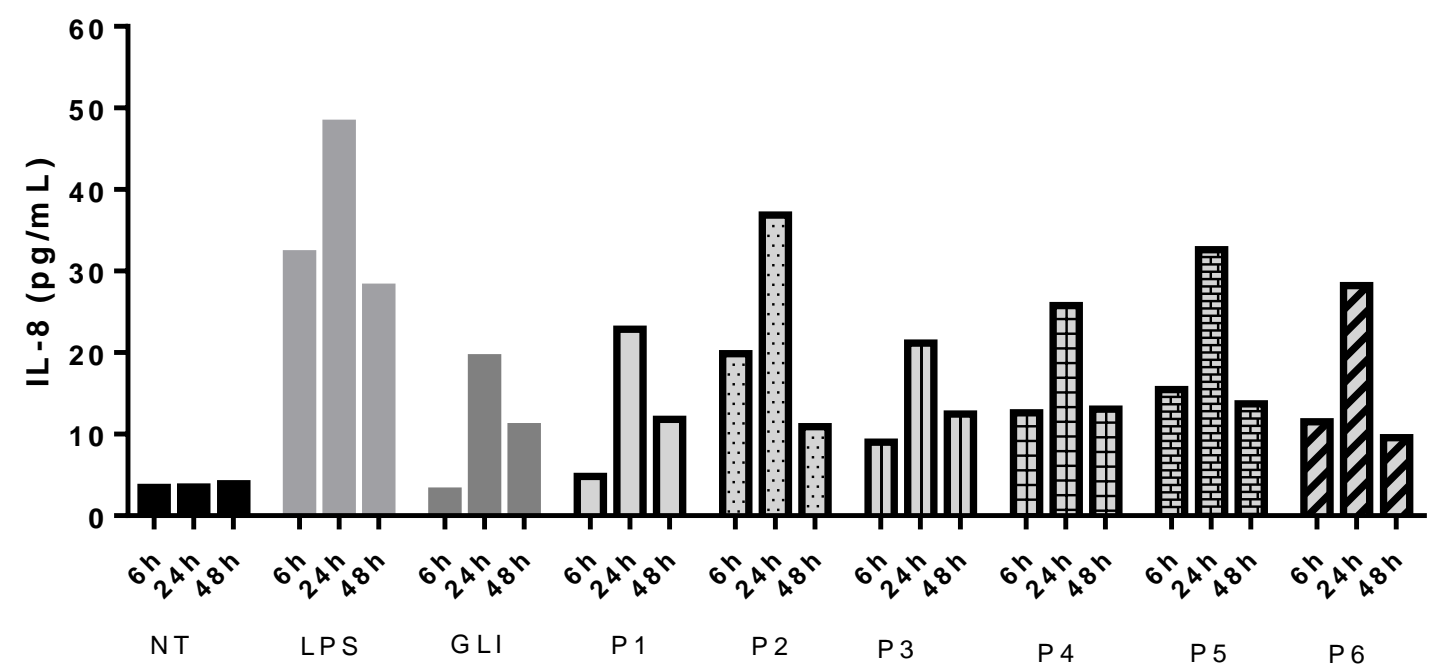

Figura 33 - Dosagem da citocina Interleucina 8 (IL-8) em sobrenadante de cultura de células Caco-2 após interação com LPS, gliadina e seus peptídeos em 6, 24 e 48h

\subsubsection{Dosagem de TNF- $\alpha$}

O fator de necrose tumoral alpha (TNF- $\alpha$ ) foi induzido e dosado nas células Caco-2 após estimuladas com LPS, gliadina e peptídeos por 6 horas, 24 horas e 48 horas. O TNF- $\alpha$ é uma citocina envolvida em várias vias inflamatórias diferentes, pode exibir papeis antagônicos por possuir mecanismos regulatórios complexos. É disparado por vírus, endotoxinas, pela IL-1 e IL-17 e inicia diversas atividades biológicas, entre elas, ativação da via NFkB. 
A quantidade observada de TNF- $\alpha$ nas células tratadas com LPS aumentou em relação ao tempo, sendo observado em baixos níveis no tempo de 6 horas, elevando-se em 24 horas e novamente em 48 horas (Figura 34). Ao contrário do que se observa em LPS, os níveis de TNF- $\alpha$ para gliadina e seus peptídeos apresentaram-se levemente reduzido em 48 horas em relação aos níveis dosados em 24 horas. Em 6 horas observouse menores quantidades de TNF- $\alpha$ para todos os estímulos, exceto para P4, quando comparados ao NT.

Os maiores níveis de TNF- $\alpha$ foram observados nas células estimuladas com o peptídeo desamidado P5 em 24 horas de interação, seguido de P1 e P6.

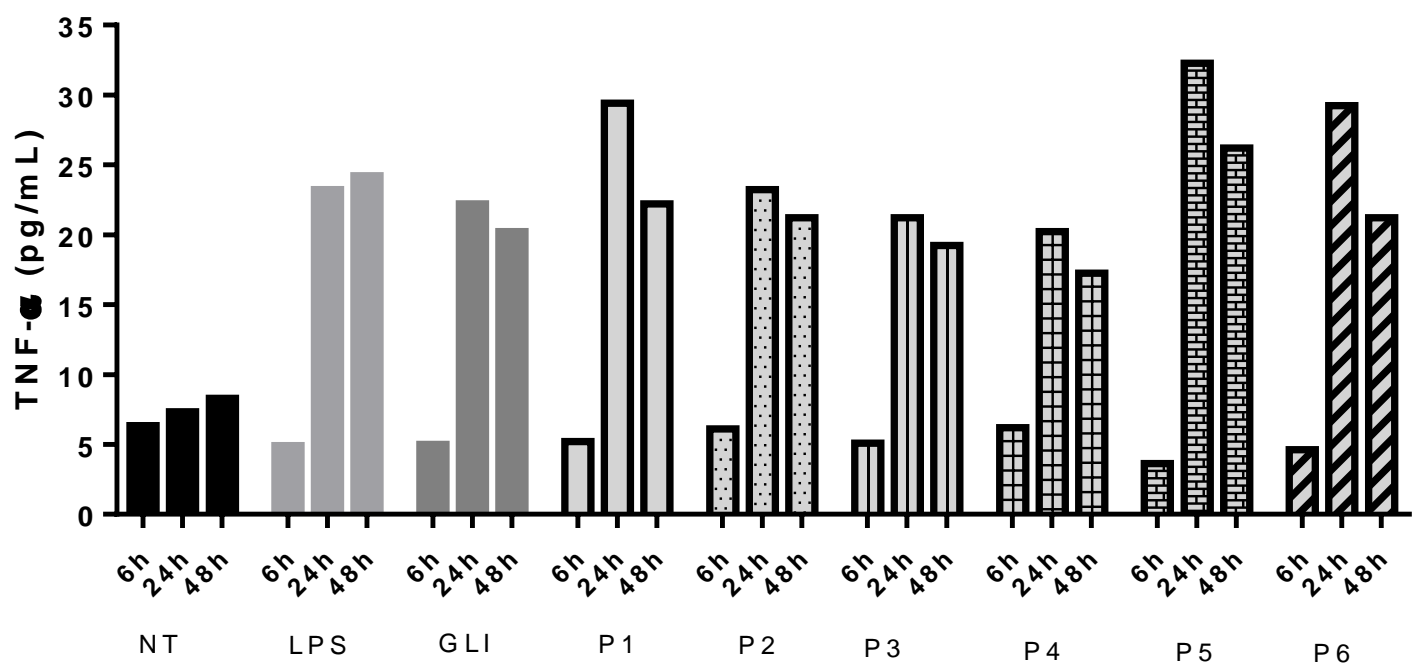

Figura 34 - Dosagem da citocina Fator de Necrose Tumoral (TNF- $\alpha$ ) em sobrenadante de cultura de células Caco-2 após interação com LPS, gliadina e seus peptídeos em 6, 24 e 48h 


\section{DISCUSSÃO}

O objetivo do presente estudo foi analisar a interação inicial da gliadina e seus peptídeos imunogênicos em células epiteliais Caco-2 e observar os mecanismos de disparos da resposta inflamatória nesse tecido na fase inicial dessa interação celular. A inflamação exacerbada desencadeada pela gliadina e seus peptídeos em células Caco-2 foi observada inicialmente pelo disparo do estresse oxidativo observado na dosagem de NO nas primeiras horas de interação com as células Caco-2, seguidas de expressão de transcritos gênicos de $I L-1, I L-6, I L-8$ e $I L-15$ especialmente nos tempos de 24 e 48 horas de interação e, na presença das citocinas destes transcritos que puderam ser evidenciadas principalmente nos tempos de 24 e 48 horas após interação.

A doença celíaca é uma desordem sistêmica, imunomediada, que combina fatores genéticos e ambientais para promover inflamação, dano na mucosa intestinal e o quadro clínico no doente celíaco. A presença do glúten na dieta é o fator ambiental necessário para desencadear inflamação persistente com infiltração de células do sistema imunitário na lâmina própria, aumento da expressão e deslocamento de anticorpos diversos para o epitélio intestinal do doente celíaco (HUSBY et al., 2012). Em especial a gliadina e seus fragmentos peptídicos entram em contato com as células da barreira epitelial e iniciam a resposta inflamatória antes mesmo que esses peptídeos atinjam a lâmina própria para serem reconhecidos pelas APCs e iniciarem a resposta mediada pelo reconhecimento via MHC-II e seus alelos predisponentes HLA-DQ2/DQ8 (SAKLY et al., 2006)

A resposta inflamatória causada nos enterócitos é consequência direta da resposta imune adaptativa e inata desencadeada pela gliadina. O fragmento 33-mer da gliadina é conhecidamente o mais imunogênico da porção $\alpha$-gliadina, é resistente a digestão gástrica e contém a maioria dos epítopos reconhecidos pelas células-T (FLECKENSTEIN et al; 2002). Os fragmentos são desamidados pela tTG2 e depois de reconhecidos induzem a resposta imune adaptativa pró-inflamatória mediada por células T. Simultaneamente, o peptídeo p31-43 causa dano no tecido epitelial in vivo e in vitro, provocando resposta imune inata através de seu maior mediador, a Interleucina 15, bem como por estresse oxidativo (MAIURI et al., 2003; BARONE et al., 2010).

As células intestinais Caco-2 tem sido usadas como modelo in vitro de barreira intestinal para estudos de toxicologia porém, problemas quanto a reprodutibilidade das 
condições de crescimento intrínsecas às Caco-2 tem dificultado a comparação dos resultados entre diferentes laboratório (NATOLI et al., 2012). Para padronizar os experimentos da interação das células Caco-2 com LPS, gliadina e seus peptídeos, foram elaborados os experimentos da fase analítica $\mathrm{I}$ que estabeleceram as concentrações de LPS e gliadina capazes de gerar respostas mensuráveis de estresse oxidativo, sem danos celulares excessivos, evitando desperdício de reagentes ao longo dos experimentos e trazendo reprodutibilidade biológica ao evento estudados (Figura 9).

As concentração dos reagentes foram testadas a partir de protocolo modificado de LAPARRA et al. (2010), RAUHAVIRTA et al. (2011), e CAPUTO et al. (2012) e geraram resultados adequados para as concentrações de $1 \mu \mathrm{g} / \mathrm{mL}$ para LPS (figura 10) e de $80 \mu \mathrm{g} / \mathrm{mL}$ para gliadina (figura 11), apresentando comportamento inflamatório semelhantes entre si nos tempos analisados neste estudo. A padronização dos ensaios de q-PCR utilizando SYBR Green seguiu protocolo de otimização sugerido pelo fabricante. Depois da fase analítica I apresentar resultados satisfatórios, foi então, iniciada a fase analítica II com a interação de células Caco-2 conforme desenho experimental proposto pelo presente trabalho.

A presença dos estímulos de LPS, gliadina e seus peptídeos nas células Caco-2, foram capazes de gerar estresse oxidativo, elevando os níveis de radicais livres presentes nas células, especialmente evidenciado pela presença de níveis elevados de NO (Figura 29). Quando em níveis elevados o estresse oxidativo pode gerar efeitos citotóxicos, principalmente durante o desenvolvimento de processos inflamatórios (KORHONEN et al., 2005). Níveis altos de óxido nítrico são descritos em pacientes celíacos não tratados que se alimentam com glúten e pode ser dosado na urina desses pacientes (HÖGBERG et al. 2011).

Dentre os efeitos citotóxicos gerados pelo estresse oxidativo está o aumento da coexpressão de genes associados à ativação da via do fator de transcrição NFkB (por exemplo, $T N F$ - $\alpha$ e $C O X-2)$, e consequentemente o aumento da expressão dos transcritos relacionados de interleucinas ( $I L-1, I L-6$ e $I L-8)$ evidenciados em cultura celular tratada com gliadina obtidas a partir de biópsias de doentes celíacos (FERNANDEZ-JIMENEZ et al. 2014). O aumento na expressão destas citocinas também foi observado em nossos resultados, demonstrando que a gliadina e seus peptídeos (P1-P6) induziram a produção destas citocinas em células Caco-2, tal como observado em células obtidas de biópsia intestinal de pacientes celíacos (figura 30-34). 
A ativação da via NFkB mediada por estresse oxidativo e expressão de IL-15 é crucial para instalar a resposta imune nos enterócitos, controlando a ativação de linfócitos e o deslocamento de células NK para atuarem na apoptose daquele tecido (DÜWEL et al., 2009). Tal como proposto na literatura, a expressão de NO e IL-15 ocorreu in vitro após estímulo das células Caco-2 com gliadina e peptídeos (P1-P6), reproduzindo o que ocorre in vivo e já foi evidenciado na patogênese da DC.

Estudos recentes tem ligado o P31-43 na ativação da resposta imune inata no enterócito, via IL-15, interferindo na maturação das vesículas endocíticas reduzindo, consequentemente, a degradação de receptores do fator de crescimento epidermal (EGFR) que é mantido ativado por mais tempo, o que resulta no aumento do sinal para proliferação celular e modificações na actina dos enterócitos além de induzir a apoptose celular em cultura de células de biópsias intestinais de doentes celíacos (BARONE et al., 2010).

No presente estudo, a presença dos estímulos de LPS, gliadina e seus peptídeos modularam positivamente a expressão dos transcritos gênicos de $I L-15$ nos tempos de 24 e 48 horas de estímulos, em relação ao NT. Este evento foi confirmado pela presença da Interleucina IL-21 e IL-2 (figura 31 e 32) no sobrenadante das células com 24 e 48 horas de estímulo.

A Interleucina 15 é membro da família de quatro ligantes $\alpha$-hélices e divide receptor de cadeia $\gamma$ com IL-2, IL-7, IL-4, IL-9 e IL-21, e compartilha também a cadeia $\beta$ com IL-2 (ABADIE \& JABRI 2014). No presente estudo, ficou evidenciada níveis elevados de IL-15 tanto no LPS e gliadina, quanto nos peptídeos. Entre os peptídeos de gliadina, se observa pouca diferença entre si na expressão dos transcritos de $I L-15$. Observa-se ainda que o p31-43 (P4) promoveu a maior expressão dos transcritos em 48 horas, quando comparado aos demais peptídeos, mas que isso não resultou em maior expressão das citocinas IL-21 e IL-2 além do observado.

No presente estudo, os estímulos de LPS, gliadina e seus peptídeos, induziram células Caco-2 a produzirem diferenças significativas de transcritos gênicos de $I L-6, I L$ 8 e $I L-1$ quando comparados com células não tratadas. Os transcritos de $I L-6$ das células estimuladas com LPS, P2, P3, P4, P5 e P6 aumentaram em relação ao tempo, sendo que em 48 horas se observam maiores quantidades. Já para os transcritos de gliadina e P1, observa-se aumento dos transcritos em 24 horas seguido de leve queda dos níveis em 48 horas. Embora os transcritos gênicos de IL-6 tenham diferenciado levemente entre os 
estímulos, tal comportamento não foi observado para a citocina IL-6, uma vez que para todos os estímulos as células Caco-2 produziram quantidades crescentes da citocina ao longo do tempo, evidenciando o disparo da produção de IL-6 quando comparado com as células NT (figura 30).

A IL-6 é uma citocina com atividade pró-inflamatória e na presença de estímulos pró-inflamatórios como LPS, viroses, IL-1 e TNF- $\alpha$, é observado um aumento nos níveis de expressão de transcritos gênicos de $I L-6$ (WOLF et al., 2014). Estudos em cultura celular de biópsia intestinal de indivíduos portadores de DC ou sensíveis ao glúten apresentaram aumento significativo dos níveis de transcritos de $I L-6$ quando expostos à gliadina, sugerindo papel dessa citocina na DC (SAPONE et al., 2011). Estudos in vitro com células Caco-2 como modelo experimental, demonstraram que quando tais células são expostas à gliadina como estímulo inflamatório, estas células expressam IL-6 e IL-8 em quantidades superiores às observadas em células não expostas, em concordância com o que se observa in vivo. Outros estudos demonstraram que Caco-2 pré tratadas com fragmento 10-mer da gliadina produziram as citocinas próinflamatórias IL-6 e IL-8 (CAPOZZI et al. 2013; LAMMERS et al., 2011).

A Interleucina 8 ou CXCL8 é produzida na presença de estímulo exógeno por macrófagos, células epiteliais, células endoteliais, dentre outras. Está relacionada a sinalização celular e estimula a habilidade dos neutrófilos e linfócitos T de infiltraremse em tecido inflamado ou danificado (WOLFF et al., 1998). Foi descrito que em monócitos de pacientes com doença celíaca, tratados na presença da gliadina, tais células foram capazes de produzir aumento nos níveis de expressão de transcritos do gene $I L-8$, quando comparados com os níveis de paciente celíacos em dieta livre de glúten. A produção de transcritos de $I L-8$ e da citocina IL-8 exercem papel fundamental no recrutamento de neutrófilos para a mucosa intestinal de paciente celíacos expostos a gliadina (LAMMERS et al., 2011).

Estudo in vitro demonstrou que células expostas a estímulos inflamatórios como gliadina e LPS tiveram seus níveis de expressão de IL-8 aumentados (TU et al., 2016). No presente estudo, foi observado que as células Caco-2 quando expostas aos estímulos de LPS, gliadina e seus peptídeos, foram capazes de produzir transcritos gênicos de $I L-8$ bem como de níveis correspondentes da citocina IL-8. Especialmente no tempo de 24 horas foi observado que os transcritos de $I L-8$ obtiveram maior expressão em relação as células não tratadas. A produção da citocina IL-8 (figura 33) 
correspondeu ao comportamento dos transcritos de $I L-8$. Observou-se, ainda, que gliadina e seus peptídeos foram tão eficientes quanto LPS para induzir a produção de níveis elevados desta citocina pelas células Caco-2, quando comparada com células não tratadas.

A gliadina gera atividade citotóxica nos enterócitos de doentes celíacos, esta atividade é mediada pela expressão de citocinas pró-inflamatórias e estresse oxidativo. A expressão dessas citocinas dá-se pela ativação da via $\mathrm{NF \kappa B}$ e consequentemente a coexpressão dos transcritos das citocinas. Esta expressão está associada a doenças inflamatórias crônicas, como por exemplo, artrite reumatoide, asma, cardiopatias e múltiplas formas de cânceres (BARNES \& KARIN 1997; LABERGE et al., 2005).

A ativação do $\mathrm{NF \kappa B}$ promove a ativação da ciclooxigenase $(\mathrm{COX})$, com posterior expressão de prostaglandinas, tromboxanos e leucotrienos, a ativação da via de iNOS e consequente produção de níveis elevados de metabólitos de NO, que contribuem ainda mais com o estresse oxidativo (DE STEFANO et al., 2007; MAIURI et al., 2003).

Receptores do tipo Toll-like (TLR) assim como os receptores do fator de necrose tumoral (TNF) e os receptores de IL-1, exercem papel fundamental na resposta imune inata regulando a ativação da via de NFאB pela fosforilação e degradação dos

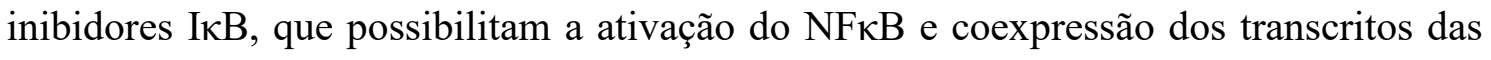
citocinas (VERSTREPEN et al., 2008). Estudos tem evidenciado que NFкB é mediador da expressão de IL-15 que ocasiona o mal funcionamento das junções TJ nas células epiteliais intestinais diminuindo a expressão de ocludina e aumentando a expressão de zonulina nessas células, fenômeno comumente relatado em doentes celíacos (SAPONE et al., 2011).

No presente estudo, ficou evidenciado a expressão dos transcritos gênicos e das respectivas citocinas pretendidas na interação das células Caco-2 com estímulos de LPS, gliadina e seus peptídeos, o que sugere fortemente a ativação da via de NFkB. Ainda foi observado que os níveis de transcritos gênicos de IL-1 foram mais elevados para P2 e P3 no tempo de 24 horas e para P4 e P5 no tempo de 48 horas em relação ao NT e que não houve modulação para os transcritos do receptor IL-1RA, exceto para P3 no tempo de 24 horas. Embora os transcritos de NFkB1 (monômero p105) tenham se comportado de forma constitutiva, não alterando a modulação para os estímulos ao longo do tempo 
em relação ao NT, isso não significa que tal transcrito não estivesse presente na célula, uma vez que houve amplificação do transcrito (Figura 14).

A modulação mais intensa observada no presente estudo foi dos transcritos de TLR-4 para os estímulos gliadina e principalmente P1 a P5 que modularam a expressão do gene com 24 e 48h, o gene P6 apresentou modulação mais expressiva apenas com $48 \mathrm{~h}$ em comparação com o NT. Essa modulação gênica talvez represente o principal resultado encontrado no estudo, demonstrando que além dos métodos de reconhecimento, interação e formas de passagem transcelular já conhecida na patogênese da doença celíaca, esse reconhecimento de gliadina e seus peptídeos por um receptor de membrana do tipo Toll-Like 4, pode sugerir uma nova rota de interação deste peptídeos que poderia aumentar a resposta inflamatória na DC.

O TLR-4 são reconhecidos com Receptores de Reconhecimento Padrão (PRR) capazes de reconhecer Padrões Moleculares Associados a Patógenos (PAMPs), são muito utilizados pela resposta imune do hospedeiro para o reconhecimento de antígenos não próprios, neste caso a gliadina e seus peptídeos. Embora essa resposta entre PAMPs e PRRs seja relatada na literatura para muitos patógenos, como os micro-organismos em geral, bactérias, fungos, entre outros, esse padrão de interação não foi relatado na literatura para a DC de maneira muito evidente, até onde pudemos constatar há apenas um estudo realizado por CSEH et al. (2011) onde a presença deste receptor TLR-4 foi marcado em células de pacientes celíacos, evidenciando que de fato o receptor está expresso em células da resposta imune nos celíacos, embora seu papel na imunopatologia da doença não tenha sido elucidado. Esse reconhecimento embora precise de estudo mais robustos e ampliados para serem confirmados, apontam para um novo caminho de reconhecimento utilizado pela gliadina e seus peptídeos, como rota de reconhecimento e amplificação da resposta inflamatória na DC.

Por fim os transcritos dos genes ocludina e zonulina apresentaram pouca modulação em relação ao NT, aumentando o número de transcritos principalmente na presença de LPS após $48 \mathrm{~h}$ de estímulo. Especificamente a zonulina teve seus transcritos gênicos modulados por mais dois peptídeos da gliadina P3 após 24 e 48h, e P4 após 48h. A ocludina recebeu modulação gênica de mais estímulos sobre seus transcritos, gliadina após 48h de estímulo, além de P1 e P4 após 48h, e P3 após 24h e 48h.

Essas duas proteínas zonulina e ocludina estão envolvidas na regulação das junções TJ, que são responsáveis pela união das células epiteliais, e controlam a 
permeabilidade celular. Alteração na regulação e produção destas proteínas, alteram a permeabilidade entre as células epiteliais e consequentemente permitem a entrada de peptídeos da gliadina na mucosa (HEYMAN \& MENARD, 2009; FASANO et al., 2011). Além disso, a presença de IL-15 prejudica a ação das junções TJ nas células epiteliais diminuindo a expressão de ocludina e aumentando a expressão de zonulina nessas células, fenômeno comumente relatado em doentes celíacos (SAPONE et al., 2011). Também sabemos que células Caco-2 quando desafiadas com glúten, expressam IFN- $\gamma$ e TNF- $\alpha$, citocinas relacionadas no aumento de expressão de proteínas das junções TJ, como por exemplo, zonulina e ocludina, aumentando a permeabilidade celular (FASANO et al., 2011). 


\section{CONCLUSÃO}

A partir dos resultados produzidos por este estudo foi possível concluir que assim como o LPS, a gliadina e seus peptídeos induzem a produção de resposta inflamatória desde as primeiras horas de interação com as células do epitélio intestinal Caco-2, e que os produtos dessa interação modulam genes de receptores como TLR-4, genes de proteínas que alteram a permeabilidade celular como zonulina e ocludina, e também de citocinas inflamatórias muito importante para a patogênese da doença celíaca. O processo inflamatório desencadeado pela gliadina e seus peptídeos alterou os níveis de mediadores de estresse oxidativo como o óxido nítrico nas células Caco-2 nos três tempos avaliados, modulou a expressão de transcritos gênicos das citocinas próinflamatórias, principalmente $I L-1, I L-6, I L-8$ e $I L-15$ especialmente nos tempos de 24 e 48 horas de interação com células Caco-2, além de modularem a expressão do gene TLR-4. Para avaliar se a modulação gênica induziu a produção destas citocinas, foram dosadas nos sobrenadantes de cultura celular nos três tempos avaliados, as citocinas IL21, IL-2, IL-6, IL-8 e TNF- $\alpha$. Os resultados evidenciaram a produção destas citocinas e confirmaram que além da modulação gênica, houve secreção destas citocinas confirmando a presença de inflamação. Após análise dos dados, podemos inferir que a gliadina intacta ou seus peptídeos íntegros ou desamidados modularam a resposta inflamatória em células Caco-2, tal como observado in vivo no doente celíaco, e que o aumento dos transcritos do gene $T L R-4$ pode representar um aumento na expressão do receptor TLR-4, que pode apresentar um papel importante na patogênese da doença, principalmente no reconhecimento da gliadina e seus peptídeos na fase de interação com as células epiteliais intestinais, bem como poderá representar uma nova rota de entrada da gliadina e seus derivados para a lâmina própria intestinal, embora estudos mais

robustos precisem responder a esta pergunta com mais ensaios laboratoriais para entender o papel deste receptor na doença celíaca. 


\section{REFERÊNCIAS}

ABADIE, V., \& Jabri, B. (2014). IL-15: A central regulator of celiac disease immunopathology. Immunological Reviews. https://doi.org/10.1111/imr.12191

ABADIE, V., Sollid, L. M., Barreiro, L. B., \& Jabri, B. (2011). Integration of genetic and immunological insights into a model of celiac disease pathogenesis. Annual Review of Immunology, 29, 493-525. https://doi.org/10.1146/annurev-immunol-040210092915

ANG, S., Kogulanathan, J., Morris, G. A., Kök, M. S., Shewry, P. R., Tatham, A. S., Harding, S. E. (2010). Structure and heterogeneity of gliadin: a hydrodynamic evaluation. European Biophysics Journal: EBJ, 39(2), 255-61. https://doi.org/10.1007/s00249-009-0529-7

BALAKIREVA, A. V, \& Zamyatnin, A. A. (2016). Properties of Gluten Intolerance: Gluten Structure, Evolution, Pathogenicity and Detoxification Capabilities. https://doi.org/10.3390/nu8100644

BARNES, P. J., \& Karin, M. (1997). Nuclear factor-kappaB: a pivotal transcription factor in chronic inflammatory diseases. The New England Journal of Medicine, 336(15), 1066-71. https://doi.org/10.1056/NEJM199704103361506

BARONE, M. V., Nanayakkara, M., Paolella, G., Maglio, M., Vitale, V., Troiano, R., Auricchio, S. (2010). Gliadin peptide P31-43 localises to endocytic vesicles and interferes with their maturation. PLoS ONE, 5(8). https://doi.org/10.1371/journal.pone.0012246

BARONE, M. V., Zanzi, D., Maglio, M., Nanayakkara, M., Santagata, S., Lania, G., Auricchio, S. (2011). Gliadin-mediated proliferation and innate immune activation in celiac disease are due to alterations in vesicular trafficking. PLoS ONE, 6(2). https://doi.org/10.1371/journal.pone.0017039

BASAK, S., Kim, H., Kearns, J. D., Tergaonkar, V., O’Dea, E., Werner, S. L.,

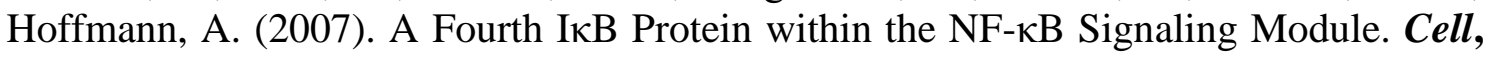
128(2), 369-381. https://doi.org/10.1016/j.cell.2006.12.033

BOLTE, G., Wolburg, H., Beuermann, K., Stocker, S., \& Stern, M. (1998). Specific interaction of food proteins with apical membranes of the human intestinal cell lines Caco-2 and T84. Clinica Chimica Acta, 270(2), 151-167. https://doi.org/10.1016/S0009-8981(97)00218-0

CAPOZZI, A., Vincentini, O., Gizzi, P., Porzia, A., Longo, A., Felli, C., ... Misasi, R. (2013). Modulatory Effect of Gliadin Peptide 10-mer on Epithelial Intestinal CACO-2 $\begin{array}{lllll}\text { Cell Inflammatory } & \text { Response. } & \text { PLSE, }\end{array}$ https://doi.org/10.1371/journal.pone.0066561

CAPUTO, I., Secondo, A., Lepretti, M., Paolella, G., Auricchio, S., Barone, M. V., \& Esposito, C. (2012). Gliadin Peptides Induce Tissue Transglutaminase Activation and ER-Stress through Ca2+ Mobilization in Caco-2 Cells. PLoS ONE, 7(9). 
https://doi.org/10.1371/journal.pone.0045209

CHANOCK, S. J., Manolio, T., Boehnke, M., Boerwinkle, E., Hunter, D. J., Thomas, G., Collins, F. S. (2007). Replicating genotype-phenotype associations. Nature, 447(7145), 655-660. https://doi.org/10.1038/447655a

CSEH, Á., Vásárhelyi, B., Szalay, B., Molnár, K., Nagy-Szakál, D., Treszl, A., ... Veres, G. (2011). Immune Phenotype of Children with Newly Diagnosed and GlutenFree Diet-Treated Celiac Disease. Digestive Diseases and Sciences, 56(3), 792-798. https://doi.org/10.1007/s10620-010-1363-6

CURTIS, B. C., Rajaram, S. (Sanjaya), \& Gómez Macpherson, H. (2002). Bread wheat: improvement and production. Food and Agriculture Organization of the United Nations.

DE STEFAnO, D., Maiuri, M. C., Simeon, V., Grassia, G., Soscia, A., Cinelli, M. P., \& Carnuccio, R. (2007). Lycopene, quercetin and tyrosol prevent macrophage activation induced by gliadin and IFN- $\gamma$ European Journal of Pharmacology, 566(1-3), 192-199. https://doi.org/10.1016/j.ejphar.2007.03.051

DUBÉ, C., Rostom, A., Sy, R., Cranney, A., Saloojee, N., Garritty, C., Avanzati, A. (2005). The prevalence of celiac disease in average-risk and at-risk Western European populations: A systematic review. Gastroenterology, 128(4), S57-S67. https://doi.org/10.1053/j.gastro.2005.02.014

DÜWEL, M., Welteke, V., Oeckinghaus, A., Baens, M., Kloo, B., Ferch, U., Krappmann, D. (2009). A20 negatively regulates T cell receptor signaling to NFkappaB by cleaving Malt1 ubiquitin chains. Journal of Immunology (Baltimore, Md. : 1950), 182(12), 7718-28. https://doi.org/10.4049/jimmunol.0803313

FARAGE, P., de Medeiros Nóbrega, Y. K., Pratesi, R., Gandolfi, L., Assunção, P., \& Zandonadi, R. P. (2016). Gluten contamination in gluten-free bakery products: a risk for coeliac disease patients. Public Health Nutrition, 1-4. https://doi.org/10.1017/S1368980016002433

FASANO, A. (2011). Zonulin and Its Regulation of Intestinal Barrier Function: The Biological Door to Inflammation, Autoimmunity, and Cancer. Physiological Reviews, 91(1).

FERNANDEZ-JIMENEZ, N., Castellanos-rubio, A., Plaza-izurieta, L., Irastorza, I., Elcoroaristizabal, X., Jauregi-miguel, A., Bilbao, J. R. (2014). Coregulation and modulation of NFkB-related genes in celiac disease: Uncovered aspects of gut mucosal inflammation. Human Molecular Genetics, 23(5). https://doi.org/10.1093/hmg/ddt520

FERRANTI, P., Mamone, G., Picariello, G., \& Addeo, F. (2007). Mass spectrometry analysis of gliadins in celiac disease. Journal of Mass Spectrometry : JMS, 42(12), 1531-48. https://doi.org/10.1002/jms.1361

FLECKENSTEIN, B., Molberg, Ø., Qiao, S.-W., Schmid, D. G., von der Mülbe, F., Elgstøen, K., ... Sollid, L. M. (2002). Gliadin T cell epitope selection by tissue transglutaminase in celiac disease. Role of enzyme specificity and $\mathrm{pH}$ influence on the 
transamidation versus deamidation process. The Journal of Biological Chemistry, 277(37), 34109-16. https://doi.org/10.1074/jbc.M204521200

FREEMAN, H. J. (2015). Emerging drugs for celiac disease. Expert Opinion on Emerging Drugs, 20(1), 129-135. https://doi.org/10.1517/14728214.2015.985204

GIOVANNINI, C., Sanchez, M., Straface, E., Scazzocchio, B., Silano, M., \& De Vincenzi, M. (2000). Induction of apoptosis in caco-2 cells by wheat gliadin peptides. Toxicology, 145(1), 63-71. Retrieved from http://www.ncbi.nlm.nih.gov/pubmed/10771132

GUTIERREZ-ACHURY, J., Zorro, M. M., Ricaño-Ponce, I., Zhernakova, D. V., Diogo, D., Raychaudhuri, S., Zhernakova, A. (2016). Functional implications of disease-specific variants in loci jointly associated with coeliac disease and rheumatoid

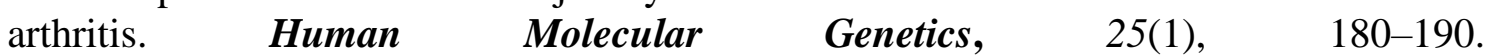
https://doi.org/10.1093/hmg/ddv455

HEYMAN, M., \& Menard, S. (2009). Pathways of gliadin transport in celiac disease. Annals of the New York Academy of Sciences, 1165. https://doi.org/10.1111/j.17496632.2009.04032.x

HISCHENHUBER, C., Crevel, R., Jarry, B., Mäki, M., Moneret-Vautrin, D. A., Romano, A., Ward, R. (2006). Review article: safe amounts of gluten for patients with wheat allergy or coeliac disease. Alimentary Pharmacology \& Therapeutics, 23(5), 559-75. https://doi.org/10.1111/j.1365-2036.2006.02768.x

HOFFMANN, A., \& Baltimore, D. (2006). Circuitry of nuclear factor kappaB signaling. Immunological Reviews, 210, 171-86. https://doi.org/10.1111/j.01052896.2006.00375.x

HOFFMANN, A., Leung, T. H., \& Baltimore, D. (2003). Genetic analysis of NFkappaB/Rel transcription factors defines functional specificities. The EMBO Journal, 22(20), 5530-9. https://doi.org/10.1093/emboj/cdg534

HÖGBERG, L., Webb, C., Fälth-Magnusson, K., Forslund, T., Magnusson, K.-E., Danielsson, L., Sundqvist, T. (2011). Children with screening-detected coeliac disease show increased levels of nitric oxide products in urine. Acta Paediatrica, 100(7), 10231027. https://doi.org/10.1111/j.1651-2227.2011.02186.x

HUSBY, S., Koletzko, S., Korponay-Szabó, I. R., Mearin, M. L., Phillips, a., Shamir, R., Zimmer, K. P. (2012). European Society for Pediatric Gastroenterology, Hepatology, and Nutrition Guidelines for the Diagnosis of Coeliac Disease. Journal of Pediatric Gastroenterology and Nutrition, 54(1), 136-160. https://doi.org/10.1097/MPG.0b013e31821a23d0

KEUNING, J. J., Peña, A. S., van Leeuwen, A., van Hooff, J. P., \& va Rood, J. J. (1976). HLA-DW3 associated with coeliac disease. Lancet (London, England), 1(7958), 506-8. Retrieved from http://www.ncbi.nlm.nih.gov/pubmed/55781

KHALEGHI, S., Ju, J. M., Lamba, A., \& Murray, J. A. (2016). The potential utility of tight junction regulation in celiac disease: focus on larazotide acetate. Therapeutic 
$\begin{array}{llll}\text { Advances in } & \text { Gastroenterology, } & 9(1), & 37-49 .\end{array}$ https://doi.org/10.1177/1756283X15616576

KORHONEN, R., Lahti, A., Kankaanranta, H., \& Moilanen, E. (2005). Nitric oxide production and signaling in inflammation. Current Drug Targets. Inflammation and Allergy, 4(4), 471-9. Retrieved from http://www.ncbi.nlm.nih.gov/pubmed/16101524

KUMAR, V., Wijmenga, C., \& Withoff, S. (2012). From genome-wide association studies to disease mechanisms: Celiac disease as a model for autoimmune diseases. Seminars in Immunopathology, 34(4), 567-580. https://doi.org/10.1007/s00281-0120312-1

LABERGE, M. A., Moore, K. J., \& Freeman, M. W. (2005). Atherosclerosis and innate immune signaling. Annals of Medicine, 37(2), 130-40. Retrieved from http://www.ncbi.nlm.nih.gov/pubmed/16026120

LÄHDEAHO, M.-L., Kaukinen, K., Laurila, K., Vuotikka, P., Koivurova, O.-P., KärjäLahdensuu, T., Mäki, M. (2014). Glutenase ALV003 Attenuates Gluten-Induced Mucosal Injury in Patients With Celiac Disease. Gastroenterology, 146(7), 1649-1658. https://doi.org/10.1053/j.gastro.2014.02.031

LAMMERS, K. M., Khandelwal, S., Chaudhry, F., Kryszak, D., Puppa, E. L., Casolaro, V., \& Fasano, A. (2011). Identification of a novel immunomodulatory gliadin peptide that causes interleukin-8 release in a chemokine receptor CXCR3-dependent manner only in patients with coeliac disease. Immunology, 132(3), 432-440. https://doi.org/10.1111/j.1365-2567.2010.03378.x

LAPARRA, J. M., Alegría, a., Barberá, R., \& Farré, R. (2008). Antioxidant effect of casein phosphopeptides compared with fruit beverages supplemented with skimmed milk against H2O2-induced oxidative stress in Caco-2 cells. Food Research International, 41(7), 773-779. https://doi.org/10.1016/j.foodres.2008.06.002

LAPARRA, J. M., \& Sanz, Y. (2010). Bifidobacteria inhibit the inflammatory response induced by gliadins in intestinal epithelial cells via modifications of toxic peptide generation during digestion. Journal of Cellular Biochemistry, 109(4), 801-807. https://doi.org/10.1002/jcb.22459

LEFFLER, D. A., Green, P. H. R., \& Fasano, A. (2015). Extraintestinal manifestations of coeliac disease. Nature Reviews Gastroenterology \& Hepatology, 12(10), 561-571. https://doi.org/10.1038/nrgastro.2015.131

LINDFORS, K., Rauhavirta, T., Stenman, S., Maki, M., \& Kaukinen, K. (2012). In vitro models for gluten toxicity: relevance for celiac disease pathogenesis and development of novel treatment options. Experimental Biology and Medicine, 237(2), 119-125. https://doi.org/10.1258/ebm.2011.011294

LOSOWSKY, M. S. (2008). A history of coeliac disease. Digestive Diseases (Basel, Switzerland), 26(2), 112-20. https://doi.org/10.1159/000116768

LUDVIGSSON, J. F., Leffler, D. A., Bai, J. C., Biagi, F., Fasano, A., Green, P. H. R., Ciacci, C. (2013). The Oslo definitions for coeliac disease and related terms. Gut, 62(1), 
43-52. https://doi.org/10.1136/gutjnl-2011-301346

MAIURI, L., Ciacci, C., Ricciardelli, I., Vacca, L., Raia, V., Auricchio, S., ... Londei, M. (2003). Association between innate response to gliadin and activation of pathogenic $\mathrm{T}$ cells in coeliac disease. Lancet, 362(9377), 30-37. https://doi.org/10.1016/S01406736(03)13803-2

MÄKI, M. (2014). Celiac Disease Treatment. Journal of Pediatric Gastroenterology and Nutrition, 59(July), S15-S17. https://doi.org/10.1097/01.mpg.0000450397.76521.f9

MARIETTA, E. V., Schuppan, D., \& Murray, J. A. (2009). In vitro and in vivo models of celiac disease. Expert Opinion on Drug Discovery, 4(11), 1113-23. https://doi.org/10.1517/17460440903307417

MATYSIAK-BUDNIK, T., Moura, I. C., Arcos-Fajardo, M., Lebreton, C., Ménard, S., Candalh, C., Heyman, M. (2008). Secretory IgA mediates retrotranscytosis of intact gliadin peptides via the transferrin receptor in celiac disease. The Journal of Experimental Medicine, 205(1), 143-54. https://doi.org/10.1084/jem.20071204

MCCARVILLE, J. L., Nisemblat, Y., Galipeau, H. J., Jury, J., Tabakman, R., Cohen, A., Verdu, E. F. (2014). BL-7010 Demonstrates Specific Binding to Gliadin and Reduces Gluten-Associated Pathology in a Chronic Mouse Model of Gliadin Sensitivity. PLoS ONE, 9(11), e109972. https://doi.org/10.1371/journal.pone.0109972

MEGIORNI, F., Mora, B., Bonamico, M., Barbato, M., Nenna, R., Maiella, G., ... Mazzilli, M. C. (2009). HLA-DQ and risk gradient for celiac disease. Human Immunology, 70(1), 55-9. https://doi.org/10.1016/j.humimm.2008.10.018

MERESSE, B., Curran, S. a, Ciszewski, C., Orbelyan, G., Setty, M., Bhagat, G., ... Jabri, B. (2006). Reprogramming of CTLs into natural killer-like cells in celiac disease. The Journal of Experimental Medicine, 203(5), 1343-1355. https://doi.org/10.1084/jem.20060028

MITCHELl, S., Vargas, J., \& Hoffmann, A. (2016). Signaling via the NFkB system. Wiley Interdisciplinary Reviews: Systems Biology and Medicine, 8(3), 227-241. https://doi.org/10.1002/wsbm.1331

MOLBERG, O., Kett, K., Scott, H., Thorsby, E., Sollid, L. M., \& Lundin, K. E. (1997). Gliadin specific, HLA DQ2-restricted T cells are commonly found in small intestinal biopsies from coeliac disease patients, but not from controls. Scandinavian Journal of Immunology, 46(3), 103-9. Retrieved from http://www.ncbi.nlm.nih.gov/pubmed/9315123

NATOLI, M., Leoni, B. D., D’Agnano, I., Zucco, F., \& Felsani, A. (2012). Good Caco2 cell culture practices. Toxicology in Vitro, 26(8), 1243-1246. https://doi.org/10.1016/j.tiv.2012.03.009

OZUNA, C. V., Iehisa, J. C. M., Giménez, M. J., Alvarez, J. B., Sousa, C., \& Barro, F. (2015). Diversification of the celiac disease $\alpha$-gliadin complex in wheat: a 33-mer peptide with six overlapping epitopes, evolved following polyploidization. The Plant 
Journal, 82(5), 794-805. https://doi.org/10.1111/tpj.12851

RAUHAVIRTA, T., Qiao, S. W., Jiang, Z., Myrsky, E., Loponen, J., Korponay-Szabó, I. R., Lindfors, K. (2011). Epithelial transport and deamidation of gliadin peptides: A role for coeliac disease patient immunoglobulin A. Clinical and Experimental Immunology, 164(1), 127-136. https://doi.org/10.1111/j.1365-2249.2010.04317.x

RIVABENe, R., Mancini, E., \& De Vincenzi, M. (1999). In vitro cytotoxic effect of wheat gliadin-derived peptides on the Caco-2 intestinal cell line is associated with intracellular oxidative imbalance: implications for coeliac disease. Biochimica et Biophysica Acta (BBA) - Molecular Basis of Disease, 1453(1), 152-160. https://doi.org/10.1016/S0925-4439(98)00095-7

RODRÍGUEZ-RAMIRO, I., Martín, M. Á., Ramos, S., Bravo, L., \& Goya, L. (2011). Comparative effects of dietary flavanols on antioxidant defences and their response to oxidant-induced stress on Caco-2 cells. European Journal of Nutrition, 50(5), 313322. https://doi.org/10.1007/s00394-010-0139-2

SAKLY, W., Thomas, V., Quash, G., \& El Alaoui, S. (2006). A role for tissue transglutaminase in??-gliadin peptide cytotoxicity. Clinical and Experimental Immunology, 146(3), 550-558. https://doi.org/10.1111/j.1365-2249.2006.03236.x

SAPONE, A., Lammers, K. M., Casolaro, V., Cammarota, M., Giuliano, M. T., De Rosa, M., Fasano, A. (2011). Divergence of gut permeability and mucosal immune gene expression in two gluten-associated conditions: celiac disease and gluten sensitivity. BMC Medicine, 9(1), 23. https://doi.org/10.1186/1741-7015-9-23

SHAMIR, R., Heyman, M. B., Koning, F., Wijimenga, C., Gutierrez-Achury, J., Catassi, C., Troncone, R. (2014). Celiac Disease. Journal of Pediatric Gastroenterology and Nutrition, 59(July), S1. https://doi.org/10.1097/MPG.0000000000000410

SHAN, L. (2002). Structural Basis for Gluten Intolerance in Celiac Sprue. Science, 297(5590), 2275-2279. https://doi.org/10.1126/science.1074129

SIMON-VECSEI, Z., Kiraly, R., Bagossi, P., Toth, B., Dahlbom, I., Caja, S., ... Korponay-Szabo, I. R. (2012). A single conformational transglutaminase 2 epitope contributed by three domains is critical for celiac antibody binding and effects. Proceedings of the National Academy of Sciences, 109(2), 431-436. https://doi.org/10.1073/pnas.1107811108

SOLLID, L. M., \& Jabri, B. (2013). Triggers and drivers of autoimmunity: lessons from coeliac disease. Nature Reviews. Immunology, 13(4). https://doi.org/10.1038/nri3407

TERGAONKAR, V. (2006). NFאB pathway: A good signaling paradigm and therapeutic target. The International Journal of Biochemistry \& Cell Biology, 38(10), 1647-1653. https://doi.org/10.1016/j.biocel.2006.03.023

TOSI, P., Gritsch, C. S., He, J., \& Shewry, P. R. (2011). Distribution of gluten proteins in bread wheat (Triticum aestivum) grain. Annals of Botany, 108(1), 23-35. https://doi.org/10.1093/aob/mcr098 
TRYNKA, G., Hunt, K. a, Bockett, N. a, Romanos, J., Castillejo, G., Concha, E. G. De, \& Almeida, R. C. De. (2012). Dense genotyping identifies and localizes multiple common and rare variant association signals in celiac disease. Nature Genetics, 43(12), 1193-1201. https://doi.org/10.1038/ng.998.Dense

TU, J., Xu, Y., Xu, J., Ling, Y., \& Cai, Y. (2016). Chitosan nanoparticles reduce LPSinduced inflammatory reaction via inhibition of NF- $\mathrm{B}$ pathway in Caco-2 cells. International Journal of Biological Macromolecules, 86, 848-856. https://doi.org/10.1016/j.ijbiomac.2016.02.015

TUIRE, I., Marja-Leena, L., Teea, S., Katri, H., Jukka, P., Päivi, S., .. Katri, K. (2012). Persistent Duodenal Intraepithelial Lymphocytosis Despite a Long-Term Strict GlutenFree Diet in Celiac Disease. The American Journal of Gastroenterology, 107(10), 1563-1569. https://doi.org/10.1038/ajg.2012.220

VACCINO, P., Becker, H. A., Brandolini, A., Salamini, F., \& Kilian, B. (2009). A catalogue of Triticum monococcum genes encoding toxic and immunogenic peptides for celiac disease patients. Molecular Genetics and Genomics, 281(3), 289-300. https://doi.org/10.1007/s00438-008-0412-8

VEERARAGHAVAN, G., Leffler, D. A., Kaswala, D. H., \& Mukherjee, R. (2015). Celiac disease 2015 update: new therapies. Expert Review of Gastroenterology \& Hepatology, 9(7), 913-927. https://doi.org/10.1586/17474124.2015.1033399

VERSTREPEN, L., Bekaert, T., Chau, T. L., Tavernier, J., Chariot, A., \& Beyaert, R. (2008). TLR-4, IL-1R and TNF-R signaling to NF- $\mathrm{BB}$ : Variations on a common theme. Cellular and Molecular Life Sciences. https://doi.org/10.1007/s00018-008-8064-8

WIESER, H. (2007). Chemistry of gluten proteins. Food Microbiology, 24(2), 115-119. https://doi.org/10.1016/j.fm.2006.07.004

WOLF, J., Rose-John, S., \& Garbers, C. (2014). Interleukin-6 and its receptors: A highly regulated and dynamic system. Cytokine, 70(1), 11-20. https://doi.org/10.1016/j.cyto.2014.05.024

WOLFF, B., Burns, A. R., Middleton, J., \& Rot, A. (1998). Endothelial cell \&quot;memory\&quot; of inflammatory stimulation: human venular endothelial cells store interleukin 8 in Weibel-Palade bodies. The Journal of Experimental Medicine, 188(9), 1757-62. Retrieved from http://www.ncbi.nlm.nih.gov/pubmed/9802987

YAMAMOTO, Y., \& Gaynor, R. B. (2004). IkappaB kinases: key regulators of the NFkappaB pathway. Trends in Biochemical Sciences, 29(2), 72-9. https://doi.org/10.1016/j.tibs.2003.12.003

ZEVIT, N., \& Shamir, R. (2014). Diagnosis of Celiac Disease. Journal of Pediatric Gastroenterology and Nutrition, 59(July), S13-S15. https://doi.org/10.1097/01.mpg.0000450396.76521.b0

ZHERNAKOVA, A., van Diemen, C. C., \& Wijmenga, C. (2009). Detecting shared pathogenesis from the shared genetics of immune-related diseases. Nature Reviews Genetics, 10(1), 43-55. https://doi.org/10.1038/nrg2489 